Portland State University

PDXScholar

1984

\title{
Effects of urbanization on the hydrologic regime of Johnson Creek, Portland, Oregon
}

William Vandewater Clement

Portland State University

Follow this and additional works at: https://pdxscholar.library.pdx.edu/open_access_etds

Part of the Earth Sciences Commons, and the Geography Commons

Let us know how access to this document benefits you.

\section{Recommended Citation}

Clement, William Vandewater, "Effects of urbanization on the hydrologic regime of Johnson Creek, Portland, Oregon" (1984). Dissertations and Theses. Paper 3541.

https://doi.org/10.15760/etd.5424

This Thesis is brought to you for free and open access. It has been accepted for inclusion in Dissertations and Theses by an authorized administrator of PDXScholar. Please contact us if we can make this document more accessible: pdxscholar@pdx.edu. 
AN ABSTRACT OF THE THESIS of William Vandewater clement for the Master of Science in Geography presented 24 July, 1984.

Title: Effects of Urbanization on the Hydrologic Regime of Johnson Creek, Portland, Oregon.

APPROVED BY MEMBERS OF THE THESIS COMMITTEE:
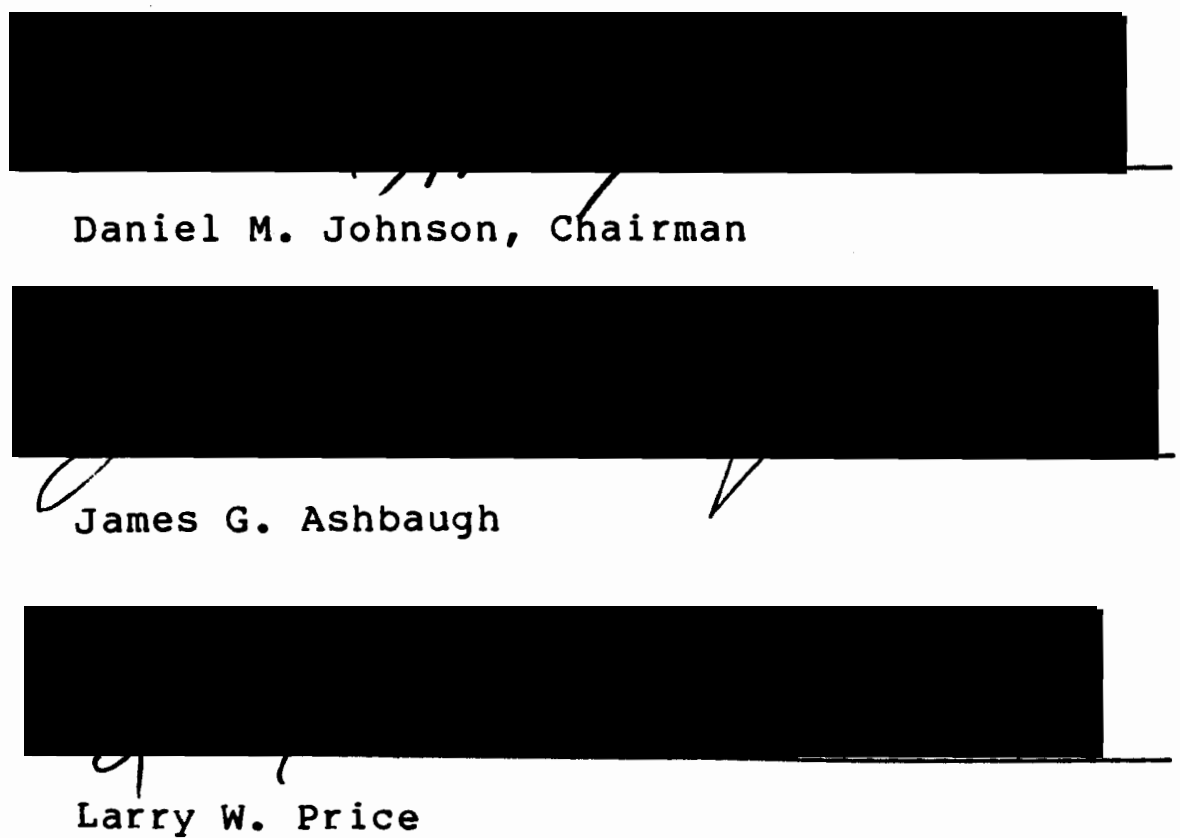

The Johnson Creek watershed, Portland, Oregon, has undergone urbanization at an increasing rate. Excessive flooding has occurred in the lower portions of the watershed, resulting in an estimated 1.5 million dollars 
worth of flood losses annually. In attempts to mitigate the flooding damages millions of dollars have been spent to channelize the creek, and over 200 thousand dollars has been spent during the last 20 years on preliminary feasibility studies alone.

The author saw a need to verify that there has been a change in the rainfall-runoff relationships in the upper Johnson Creek basin since 1941 and to quantify this change through the analysis of key hydrologic parameters. To accomplish this, extensive background research was conducted to gather as much extant information as possible about the climatic and physiographic characteristics that affect the basin hydrology. The watershed was found to have many distinct physiographic sub-areas comprised of different underlying geology, soils, geomorphic areas, slopes, vegetation patterns, and land use types that result in a complex interaction between the watershed input (precipitation) and the watershed output (runoff at the stream gage).

Precipitation and runoff data were collected on an annual basis and for specific storms throughout the study period (1941-1982). The annual data were subjected to a variety of comparative statistical tests and graphical comparisons. The storm data were reduced to unit hydrographs, averaged for several different time periods throughout the study 
period, and analyzed for changes in shape and lag time. The annual data were first tested to see if they fit the assumptions for parametric statistical tests. As they did not, they were then subjected to a number of non-parametric comparative statistical tests. As a result, the possible effects of a climatic change were eliminated as a cause for hydrologic change. Minimum flows and peakflows showed a statistically significant decrease and increase respectively. A time series/regression analysis was performed on the annual data to detect any apparent progressive change in the hydrologic parameters. The results indicate that peakflows possessed a significant positive slope and that minimum flows possessed a negative slope with an observed significance level close to the chosen significance level. The unit hydrograph analysis indicated an increase in unit hydrograph peak flows, a shortening of the unit hydrograph time to peak, a steepening of both the rising limb and the recession curve, and a reduction in precipitation event-hydrograph peak lag times. Thus the null hypothesis of no change in the rainfall-runoff relationship was discredited. The population in the area of the watershed had increased by more than 1526 percent during the study period, and as a result the one tailed alternate hypothesis of a significant hydrologic change due to urbanization was accepted. 


\title{
EFFECTS OF URBANIZATION ON THE HYDROLOGIC REGIME OF JOHNSON CREEK PORTLAND, OREGON
}

\author{
BY
}

WILLIAM VANDEWATER CLEMENT

A thesis submitted in partial fulfillment of the requirements for the degree of

\author{
MASTER OF SCIENCE \\ in
}

GEOGRAPHY

Portland State University 
TO THE OFFICE OF GRADUATE STUDIES AND RESEARCH:

The members of the committee approve the thesis of William Vandewater Clement presented 24 July 1984 .
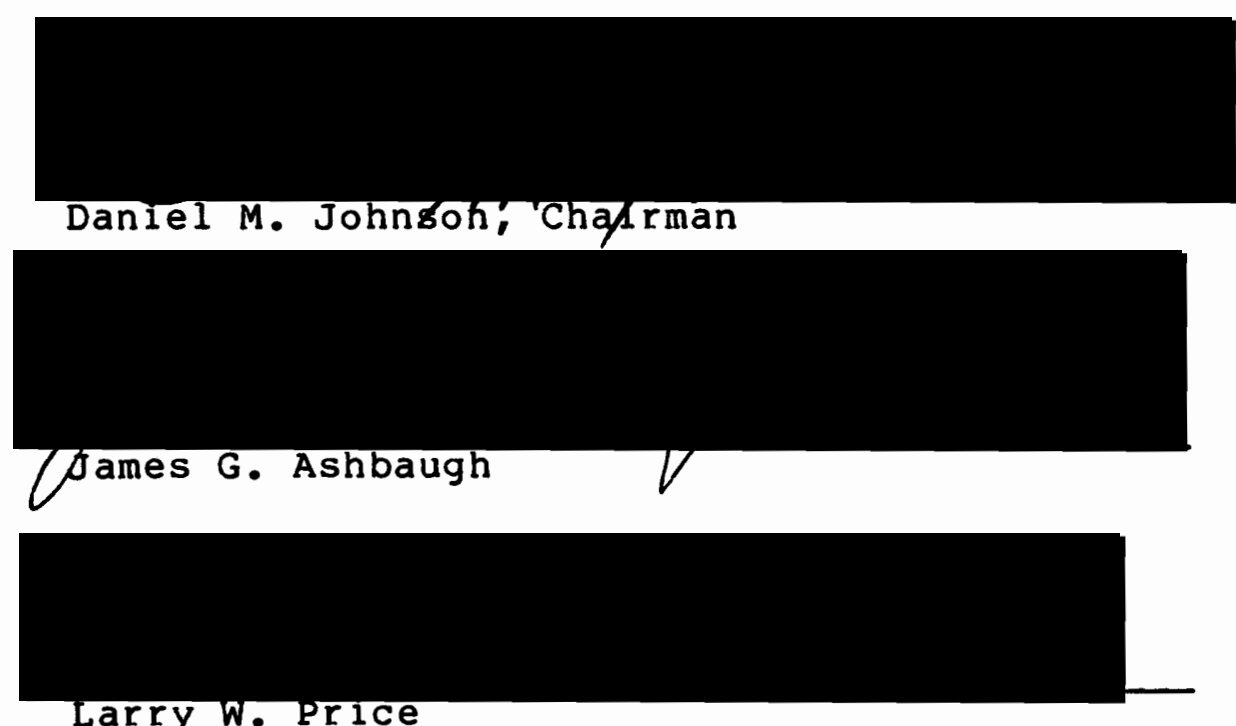

\section{APPROVED:}

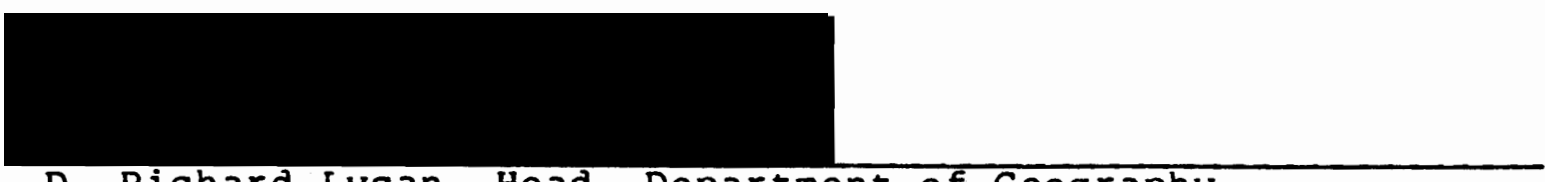

D. Richard Lycan, Head, Department of Geography

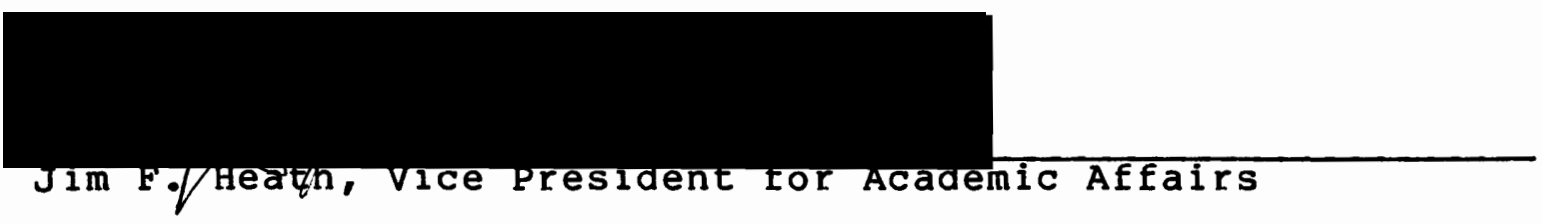




\section{ACKNOWLEDGEMENTS}

First I would like to thank my parents and family for their support of my educational endeavors.

Almost everyone in the Geography Department at P.S.U. helped me out at times. Dr. Dan Johnson started my interest in water resource subjects, made invaluable suggestions, and kept my enthusiasm high. Drs. Joe Poracsky and D. Lycan volunteered much of their time helping me develop my skills with computers and statistics. Prof. Ellen Bartsch helped me with cartography, SPSS, and gave general moral support. Carolyn perry imparted necessary information about PSU facilities and requirements and generally smoothed the way. Valuable suggestions were received from Dr. Roy Koch of Engineering and Prof. Jack Churchill of Public Administration. The staff of many government agencies provided their time and access to their data, most notably Dr. Ethan seltzer of the City of Portland.

The above persons might just say that they were only doing their job, but without their willing cooperation and personal interest in the project of an unfunded student researcher, this thesis would not have been possible. 
TABLE OF CONTENTS

PAGE

ACKNOWLEDGEMENTS

LIST OF TABLES

LIST OF FIGURES

CHAPTER

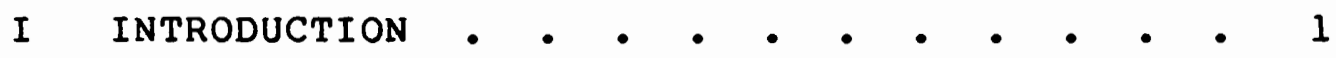

Purpose • • • • • • • • • • • 5

Methodology • • • • • • • • $~ 5$

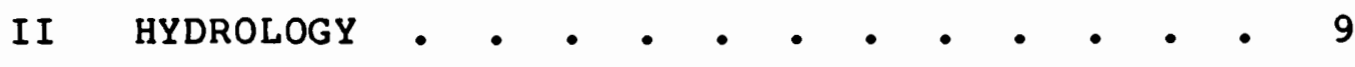

Hydrology • • • • • • • • • • • 9

Urban Hydrology • • • • • • • • • 13

Runoff

Water Quality

Thesis Area Studies

Runoff

water Quality

II THE JOHNSON CREEK WATERSHED • • • • • 27

Climate • • • • • • • • • • 27

Landforms • • • • • • • • • • 37

Geology 
Surficial Topography

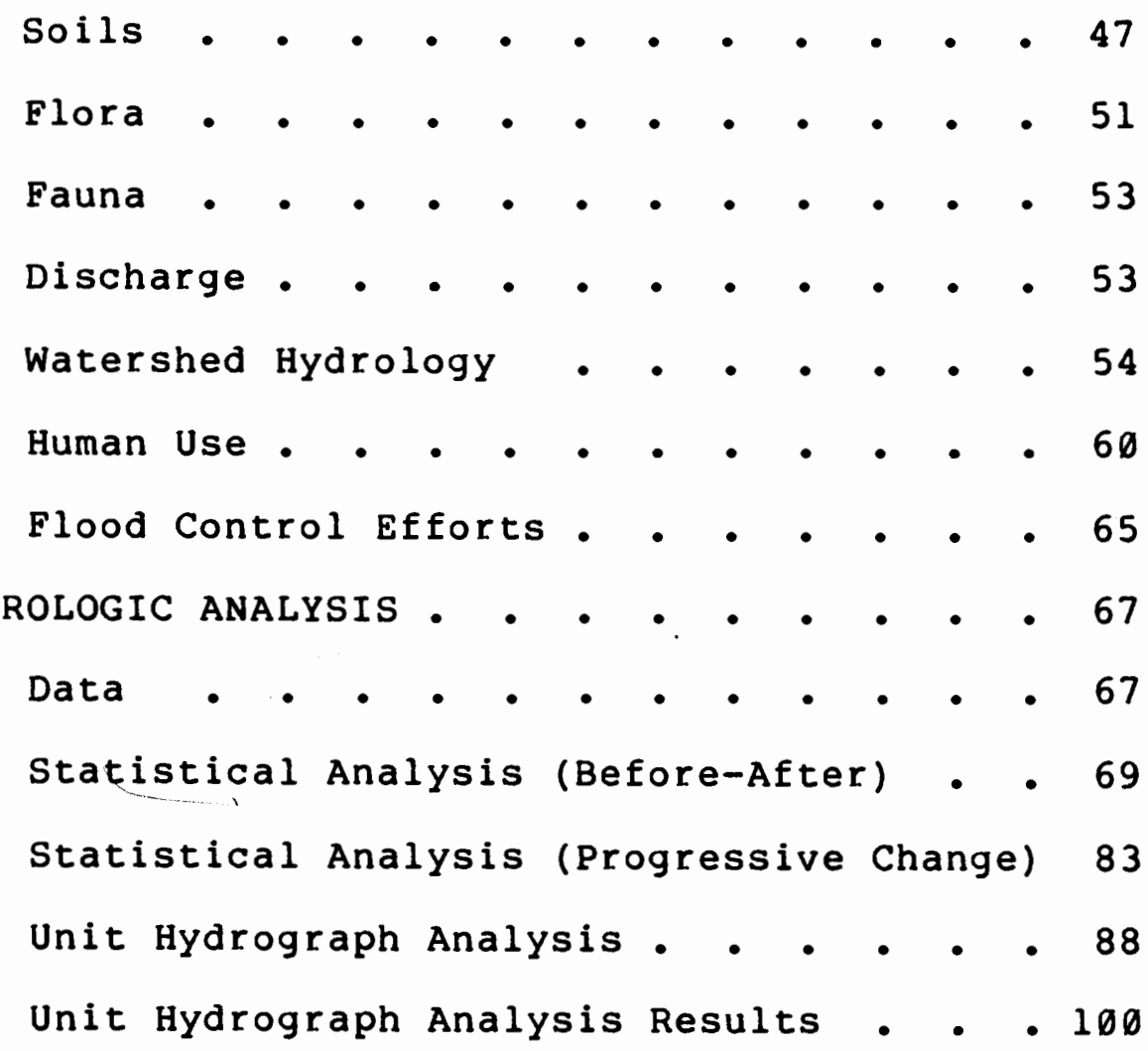

V CONCLUSION • • • • • • • • • • • • 106

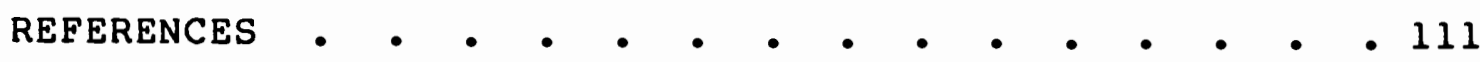


LIST OF TABLES

TABLE

PAGE

I Johnson Creek Watershed Physical

Characteristics • • • • • • • • • 46

I Johnson Creek Watershed Soil

Characteristics . • . . . . . . . 49

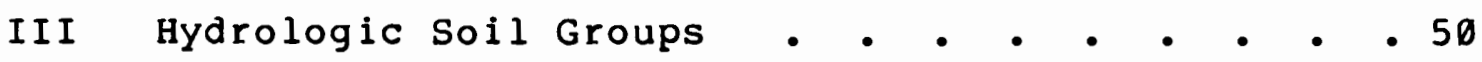

IV City of Gresham Population Growth • • • • • • 65

$V$ Results of Tests for Violations of

Assumptions $\quad$ - $\quad$ - $\quad$ - $\quad$ - $\quad$ - 77

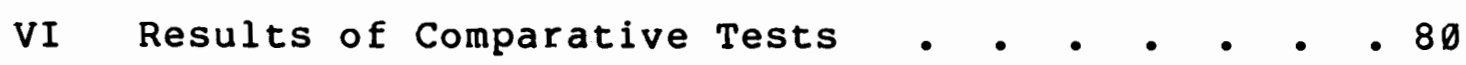

VII Comparisons of Means and Medians • $\quad$ - $\quad$ - $\quad$ - 82

VII Annual Data Linear Regression Analysis • • • $\quad 87$

IX Storm Characteristics • • • • • • • • • 102 
LIST OF FIGURES

FIGURE

PAGE

1. Johnson Creek Drainage Basin Location Map - 4

2. The Watershed Cascading System - • - • - 10

3. Urbanization and Stormwater Runoff. • • - 14

4. Average 15 Minute Hydrographs of Sharon

Creek, California • • • - • • - $\quad 20$

5. Predominant Summer and Winter Weather

Regimes • • • • • • • • • • $~-~ 28$

6. Average Monthly Precipitation and Temperature

at Portland (city) oregon . . . . . 29

7. Johnson Creek and Vicinity Average Annual

Precipitation • • • • • • • • 31

8. Portland (city) Annual Average

Precipitation (194l-1982) • • • • . 32

9. Portland (City) Coefficient of Variation • - 33

10. Portland (City) Annual precipitation

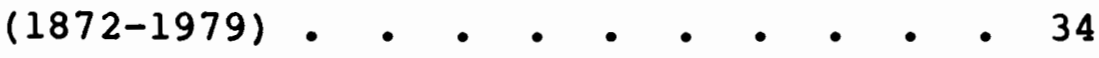

11. Portland (city) Intensity-Duration-

Frequency Curves • • • • • • • 36

12. Underlying Geology of Johnson Creek

and Vicinity • • • • • • • • • 38 
vi i

FIGURE

PAGE

13. Johnson Creek Watershed Geomorphic

Surfaces as Delineated by Hogenson . $\quad 40$

14. Johnson Creek Watershed Slope Map • • • 42

15. Johnson Creek Watershed Geomorphic

Surfaces as Delineated by The SCS. • • 43

16. Johnson Creek Long Stream Profile • • • 45

17. Johnson Creek Watershed Soils • • • • 48

18. Johnson Creek Average Monthly Flow • • • 55

19. Johnson Creek Monthly Maximum Flow • • • 56

20. Johnson Creek Monthly Minimum Flow • • • 57

21. Johnson Creek Flood Frequency Curve • • - 58

22. City of Gresham Population Growth • • • $\quad 62$

23. Johnson Creek Watershed Building Permit

Activity 1960-1980 • • • • • • • 63

24. City of Gresham Storm Sewers and

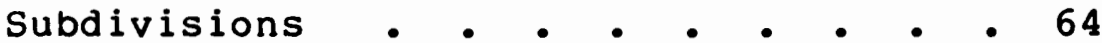

25. Johnson Creek Annual Total Flow • • • • 70

26. Johnson Creek Annual Minimum Flow • • • 71

27. Johnson Creek Annual Peak Flow • • • • 72

28. Johnson Creek Watershed Annual Total

Precipitation • • • • • • • •

29. Johnson Creek Watershed Annual Summer

Precipitation • • • • • • • • $~ 74$

30. Johnson Creek Peakflow Cumulative Plot • • 85 
31. Johnson Creek Minimum Flow Cumulative Plot • 86 32. Linear Regression of Peakflows vs.

$$
\text { Water Year • • • • • • • • } 89
$$

33. Linear Regression of Minimum Flows vs.

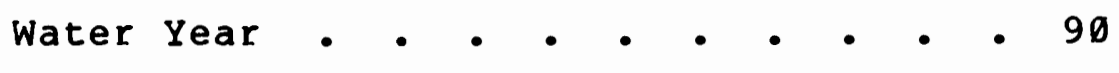

34. Unit Hydrograph Calculation Method • • • 91

35. A Unit Hydrograph comparing surfaces of $\emptyset$,

50, and 1008 permeability • • • • 94

36. Johnson Creek Average Unit Hydrographs • • 101

37. Johnson Creek Flood Frequency Curves • • 109 
CHAPTER I

INTRODUCTION

Urbanization is a process that significantly alters the surface of a natural watershed and its response to hydrologic inputs. The hydrologic impact of urban development is due to the increase in the amount of impervious area in the watershed, the increased compaction of soils, and the changes in channel location and morphology that result from the building of storm drains and the straightening of natural channels. These impacts are evinced by changes in the rate of removal of runoff from the watershed and in the water quality of the streamflow. The frequency of flooding is increased, flood stages are heightened, and the response time of the watershed is decreased. These three effects tend to increase the economic losses suffered by those living in flood prone areas in the basin. In addition, the dry season baseflow is decreased, thus contributing to a decline in the chemical and biological quality of the water, increased sediment content, and increased turbidity. 
Due to the significant environmental and economic impacts resulting from urbanization of a natural watershed, there is an urgent need for increased understanding of the urban runoff process. Each watershed has different physical, climatic and anthropogenic characteristics, and any study that approaches the urban runoff process from only one viewpoint cannot hope to recognize and deal with the whole problem. As an indicator of the need for an interdisciplinary approach, a perusal of the bibliographies from many urban hydrology studies shows citations from journals in engineering, environmental studies, mathematics, soils, planning, hydrology, and geography. Geography is an interdisciplinary field that is best suited to synthesizing the areally expressed portions of these disciplines. The man-land relationship is also a concept that has long characterized studies of a geographic nature, and a holistic approach to these relationships in an urban context is imperative when studying urban hydrology.

The effects of urbanization on watershed runoff have been studied by many authors in many different watersheds. Good overviews of the problem have been presented by Leopold (1968) and Lazaro (1979). Site-specific studies include James (1965) in Sacramento, California; Brater (1968) in Detroit, Michigan; Seaburn (1969) near New York, New York; Anderson (1968) near washington, D.C; and Laenen (1980) in 
Portland, Oregon.

Johnson Creek is located in the southeast suburban fringes of the Portland, Oregon, metropolitan area (Fig. 1), and is a typical example of full scale urbanization and the role it plays in modifying the hydrologic cycle. The eastern two-thirds of the watershed is mostly rural, becoming increasingly urbanized throughout its lower reaches. A stream gaging station (USGS \#14211500) was established in 1941 at sycamore, a location two thirds of the way up the stream from its confluence with the Willamette River. The City of Gresham is located a short distance above the gaging station, and has undergone increasing urbanization since 1941 .

The area below the gaging station has been settled since the mid 19 th century. Property near the channel has suffered extensive damage as the channel is of insufficient size to contain stormflows and extensive building has occurred within the floodplain. It has been hypothesized that the flooding has increased in recent years due to increased urbanization in the upper watershed (Laenen,1980, and Seltzer, 1983). A recent newspaper article (The Gresham Outlook, 25 Jun 1981) quoted Gresham city planners as saying, "Flood frequency and severity has increased along Johnson Creek as the watershed has urbanized". The same article noted that a storm in late 1980 that had a 20 to 30 
Johngon Creek Drainage Basin

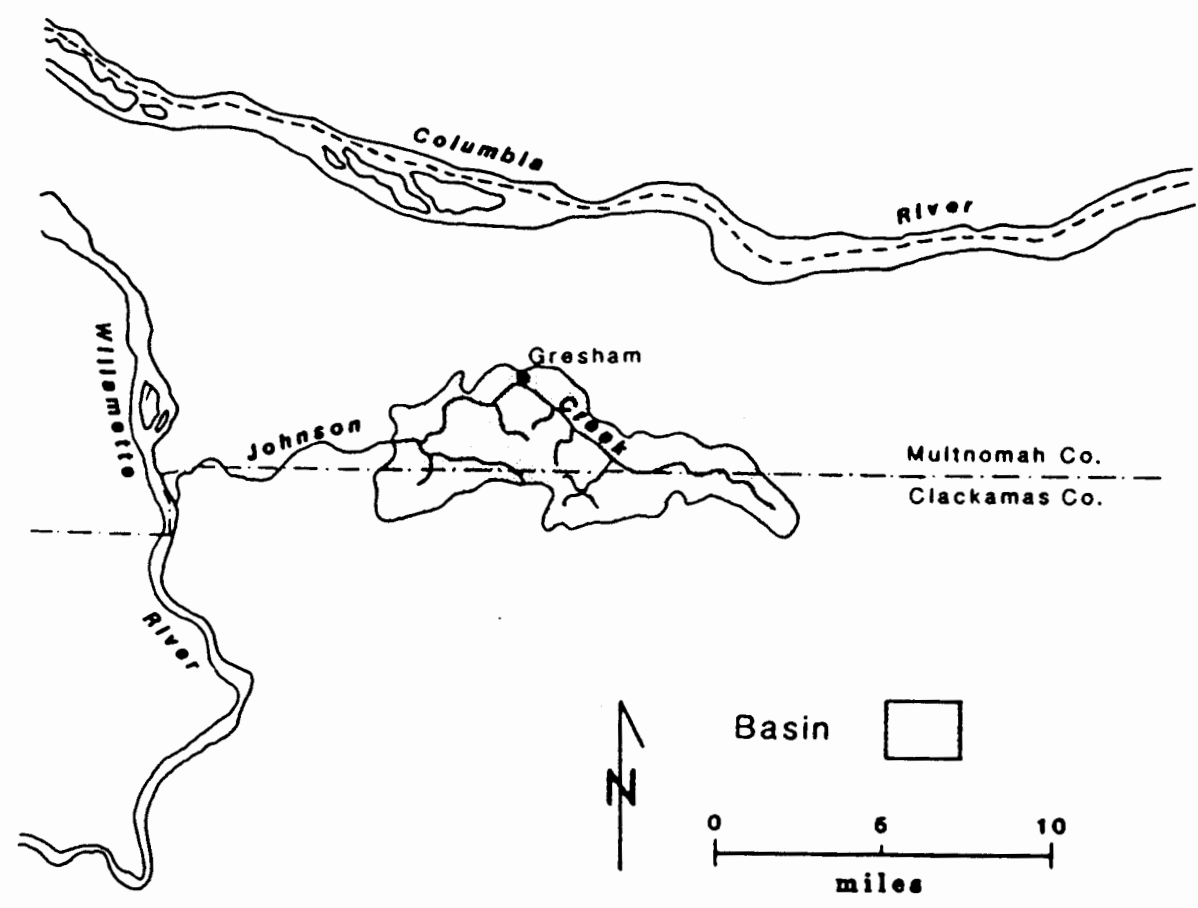

Figure 1. Johnson Creek Drainage Basin Location Map. (Source: USGS Topographic Maps) 
year return period resulted in a flood that inundated the flood plain to an elevation above the previously calculated 500 year return-period flood line. There has been much study and concern about the effects of urbanization on the rainfall-runoff cycle in Johnson Creek, but no historical analysis (documenting a change over time) has been performed.

\section{PURPOSE}

The purpose of this study is to verify that there has been a change in the rainfall-runoff relationships in the upper Johnson Creek basin since 1941 and to quantify this change through the analysis of key hydrologic perameters.

\section{METHODOLOGY}

The hydrologic regime of the creek was documented by several qualitative and quantitative techniques:

1. A statistical analysis of key hydrologic parameters (in an annual data series), comparing two twenty year periods which represent "before" and "after" urbanization conditions.

2. A time series/regression analysis to detect any possible progressive change. 
3. A comparison of average unit hydrographs from the 1940's, 1960's, and 1980's.

The annual data series chosen for the before-after and time series/regression analysis consisted of:

(1) Total annual flow (cfs)

(2) Annual peakflow (cfs)

(3) Minimum annual flow (cfs)

(4) Total annual precipitation (inches)

(5) Summer precipitation (May through september) (inches)

The data used for the unit hydrograph analysis consisted of precipitation and runoff data from several representative storms from each time period.

Metric units are usually considered the standard scale of measurements used for scientific purposes; however the majority of the data were only available in English units. In addition, the author felt that most of the persons using this report as a source of information about the Johnson Creek watershed would be more aquainted with English units, hence English units are used throughout this report.

The streamflow annual data series were analyzed initially to demonstrate that changes had occured during the period of study (1941 to 1982). The precipitation annual data series were analyzed to ensure that any changes in the streamflow were not caused by any changes in the 
precipitation.

The annual precipitation and streamflow series were broken up into two twenty-one year periods, and subjected to a number of comparative statistical tests to see if a statistically significant (.05 significance level) change had occured. There were two reasons that the period of record was split into two equal time periods. The first reason was that most of the population increase occured during the last two decades of the study period. The second reason was that an equal sample size ensured that the comparative statistical tests would have the highest significance levels possible. For purposes of the statistical analysis the author first assumed that the rainfall-runoff relationship had not changed during the study period (the null hypothesis). If the null hypothesis was disproved an attempt would be made to accept an alternate one tailed hypothesis that the rainfall-runoff relationship had changed as a result of urbanization.

The second technique used included a regression analysis and visual analysis of cumulative frequency distributions and time series graphs of the annual data.

The third technique consisted of the development of an average unit hydrograph produced from several representative storms from the early 1940's that was compared with two similar average unit hydrographs developed from storms during the early 1960's and 1980's. The methodology will be treated 
in more detail in a later chapter.

In addition, the author saw a need to do a thorough compilation of information describing the physical characteristics of the Johnson Creek watershed. Each characteristic has its own individual effect on the rainfall-runoff relationship, and a proper evaluation of the rainfall-runoff data requires such information. 
CHAPTER II

\title{
LITERATURE REVIEW
}

\author{
HYDROLOGY
}

The basic structure of hydrology (e.g, the hydrologic cycle) has been identified by Chorley and Kennedy (1971) as a cascading system (Fig. 2). They describe it as a dynamic structure "within which the output from one subsystem forms the input for the next subsystem and within which a 'regulator' may operate either to divert a part of the input of mass or energy to a 'store' or to create a throughput, creating the subsystem output" (Chorley and Kennedy 1971, p. 77). The major inputs to a drainage basin subsystem are solar energy and precipitation.

Water that falls directly on a drainage basin is disposed of in two ways, evapotranspiration and runoff. Some of the precipitation is evaporated from leaf surfaces, the ground surface and free standing water surfaces. The amount of water that evaporates is dependent on the ambient air temperature, humidity, wind, atmospheric pressure, solar 


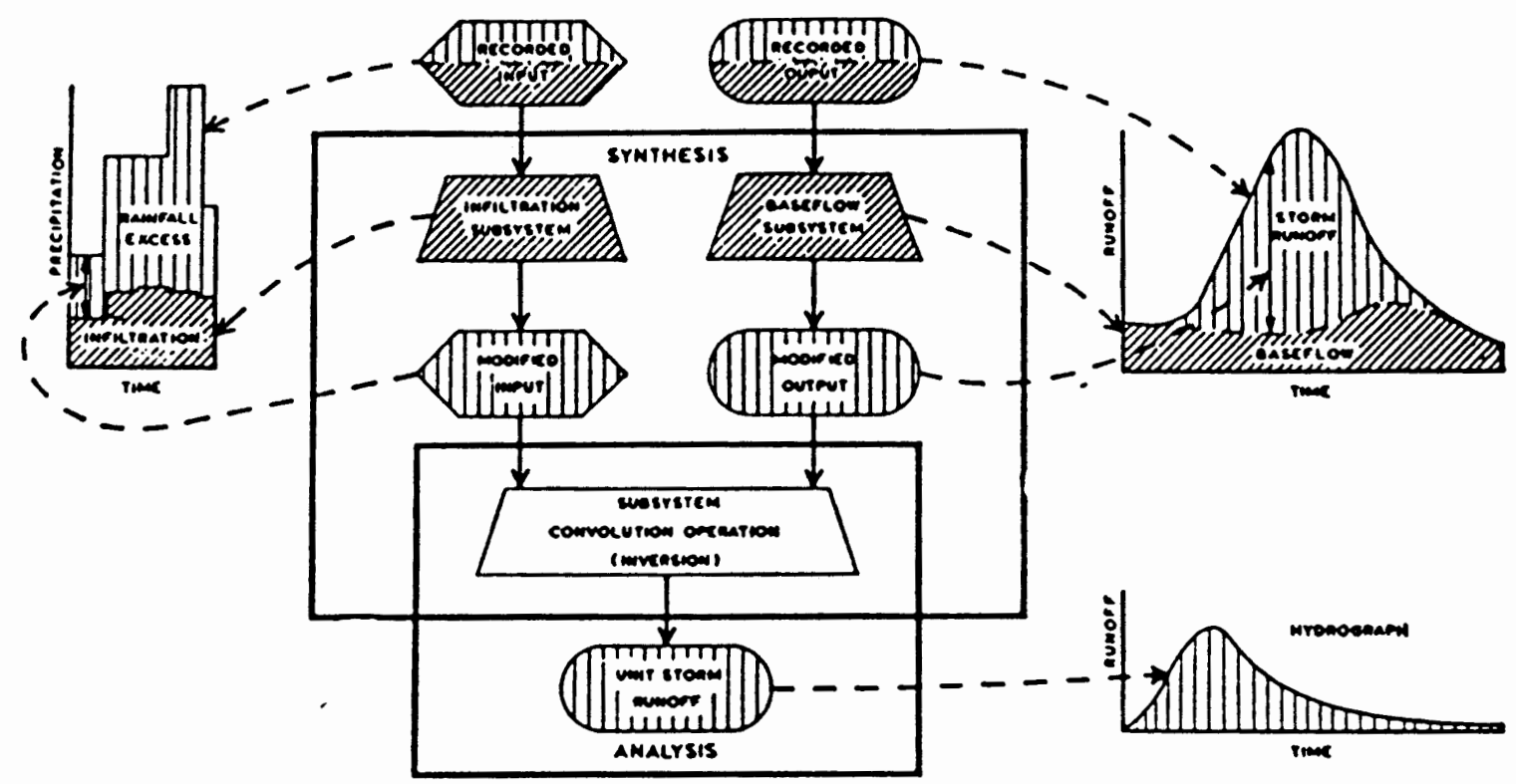

Figure 2. The Watershed Cascading System (Chorley and Kennedy, 1971, p. 123) 
radiation and the leaf area of the vegetation. Other precipitation that soaks into the soil is used by vegetation during its growing cycle and transpired into the atmosphere. These two abstractions combined (evapotranspiration) are not very significant to runoff processes in regions that experience seasonal fluctuations of temperature and a dominant winter precipitation pattern. This is because the majority of precipitation occurs when the vegetation is dormant, the deciduous trees have lost their leaves, the temperature is low, the humidity is high, and solar radiation is at a minimum.

Runoff can be separated into two major components, surface flow and subsurface flow. Subsurface flow is composed of baseflow and subsurface stormflow. Baseflow is composed of precipitation that infiltrates to the water table and then resurfaces at the stream channel. The movement of baseflow is very slow (usually requiring several months to reach the stream) and forms the principal component of the dry season streamflow. Subsurface stormflow (interflow) occurs mainly in areas where a shallow layer of highly permeable soil occurs near the surface. This process is especially important where an impermeable layer underlies the topsoil. When subsurface stormflow reaches the water table near the stream it runs out onto the surface and is called return flow. The rate of 
flow of subsurface stormflow depends on the surface slope and the soil permeability, and can take from one to 30 hours to appreciably affect the stream level.

When the rainfall intensity exceeds the soil infiltration rate the excess water runs downhill on the soil surface, and is known as Horton overland flow. The rate of flow of overland flow and return flow can be as much as 100 times as fast as that for subsurface stormflow, and may result in an almost immediate rise in stream level. The area of the watershed where overland flow and return flow are active may not be a large percentage of the total watershed area, but these runoff sources are very significant in their contribution to the rate and amount of stream rise.

Between the subsystem input (precipitation) and output (at the basin outlet) a certain amount of water is stored by the vegetation, soils, and geologic strata, and as surface water in transit over slopes, floodplains, and in stream channels. The surficial characteristics of the basin (e.g., morphometric characteristics, slope, soil permeability, vegetation type and density, and human alteration) determine how much water will remain in storage in the basin and for how long. The rate of water transmission and the amount in storage will determine the height of the flooding downstream (stage) and how soon the flood will occur after the rain 
falls (lag time). Any number of hydrology texts will give additional information on basic runoff processes. (e.g.. Dunne and Leopold (1978), or Chow (1964)).

\section{URBAN HYDROLOGY}

The term urban hydrology has attained acceptance in recent years and is defined as the interdisciplinary science of water and its relationships with urban man (Jones, 1971). As a branch of hydrology, urban hydrology is a young science, and has only come into its own since the 1960's (Lazaro,1979). Earlier studies that approximated the field mainly resulted in engineering works designed to flush out the excess runoff.

The effect of urbanization on the hydrology of a watershed is manifested in two major ways: a degradation in the water quality of the stream and a change in the rainfall-runoff relationship in the watershed. The effect of urbanization on the runoff response of a watershed is evinced in several ways: a reduction in the basin lag time; an increase in runoff volume and peak flow (coinciding with a reduction in the return periods of floods of different magnitudes); and a lower dry season baseflow (Fig. 3). Although a change in the water quality (excepting large 


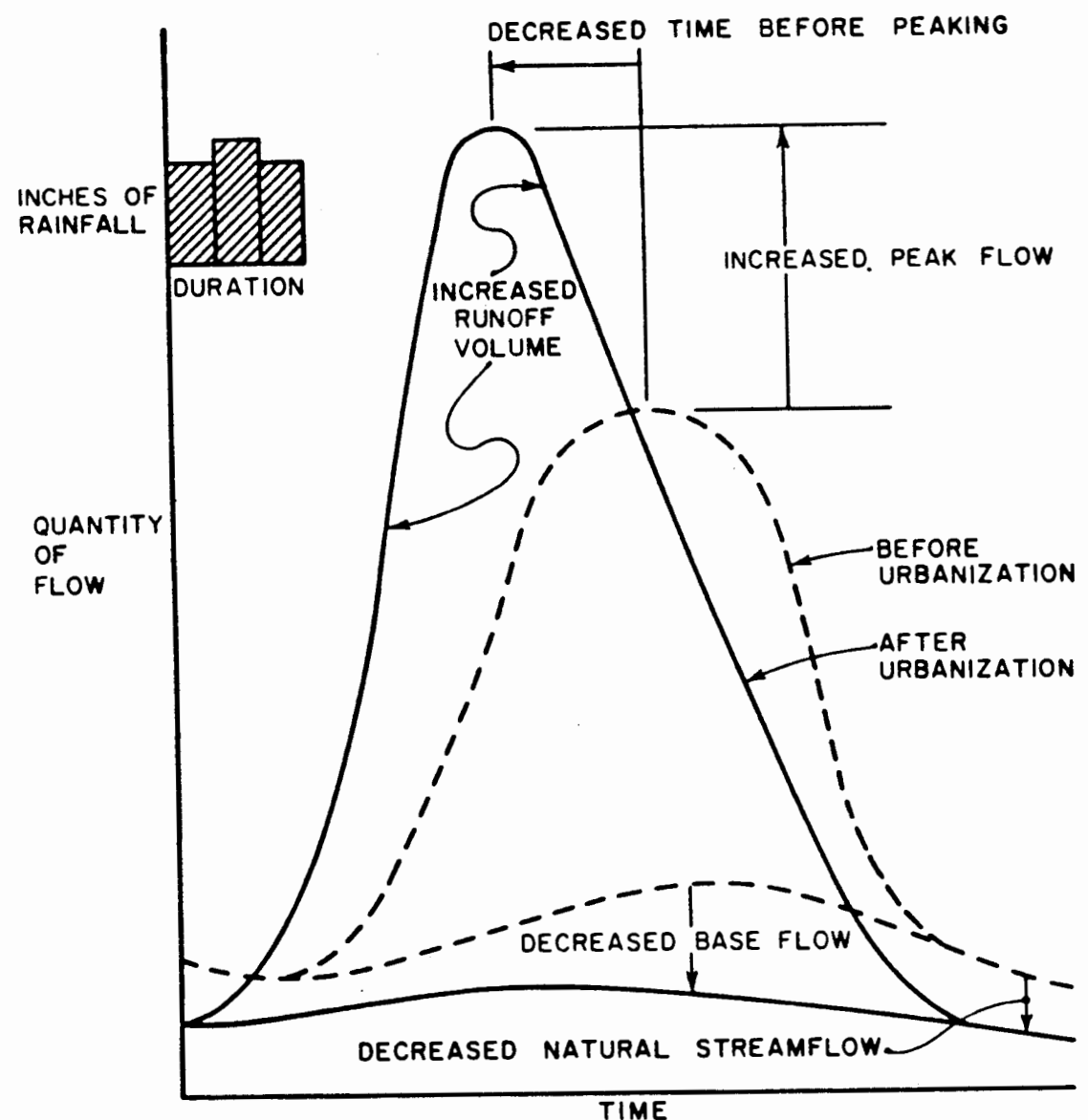

Figure 2 Urbanization and Stormwater Runoff (Corps of Engineers, date unknown) 
amounts of sediment) will not appreciably affect the stream response, a change in the stream response may have a marked effect on the stream water quality. Leopold (1968) presented a summary of then current knowlege about the effects of urbanization on water quality and quantity. His report was directed towards persons with non-technical backgrounds and is a valuable introductory reference.

\section{Runoff}

The first studies in urban hydrology were done by the engineering profession in an effort to empirically estimate the size of urban drainage systems that would be needed to effectively remove excess rainfall from urban areas. Mulvaney (1851), while trying to design more effecient drainage systems for Irish cities, realized that previous predictive equations were not developed from enough data and did not take into account the time of concentration. He noted that the ratio of rainfall to runoff could be determined by studying the soil types and land use within the watershed. He is generally credited with being the originator of the well known rational runoff formula, in which runoff is expressed as a function of (1) an empirically derived coeffecient representing the ratio of runoff to rainfall, (2) the intensity of rainfall for the estimated time of concentration, and (3) the size of the 
the size of the drainage basin. Less than a year later Manning (1851) noted that urban drainage works could increase peak flows and reduce the time of concentration. He also pointed out the importance of taking antecedent conditions into account. The first use of the rational runoff concept in the United States was in 1889, when Kuichling applied it to storm systems in Rochester, New York. He noted that, "larger quantities of storm water run off from urban surfaces than is commonly supposed, and hence it is obvious that a more rational method of sewer computation is urgently demanded" (Kuichling, 1889, p. 42). He suggested estimating the "probable future amount of impervious surface on the given area, ...with reference to the density of population... and to assume that all of the water which falls on such surface will run off without loss" (Kuichling, 1889, p. 26).

Horner and Flynt (1936) took Sherman's (1932) work on the unit hydrograph (described in Chapter IV of this thesis) and expanded the rational runoff equation in order to take into account variable rainfall intensities. Hicks (1944) analysed urban rainfall-runoff relationships to try and determine overland flow rates, infiltration losses, and the quantities of water in gutter and sewer storage. Snyder (1938) modeled the unit hydrograph by quantifying the relationship between drainage basin characteristics and three factors that define the shape of the resulting unit 
hydrographs: basin lag time, peak flow, and the unit hydrograph time base.

Prior to the early 1960's most urban hydrology studies were of an empirical nature. With the advent of electronic computers came the ability to develop and test more complicated hypotheses, and sophisticated modeling techniques for watershed analysis were constructed that could take many more variables into account. One of the pioneer studies in this area was by Tholin and Keifer (1960) who developed the "Chicago Hydrograph method of sewer design [which] evaluates, in detail, the rainfall abstractions and flow detentions which intervene between the hyetograph of rainfall and the hydrographs of sewer supply and sewer outflow" (Tholin and Keifer, 1960, p. 1308). Their work included studies on the depth of water retention on different surfaces and the variation in infiltration capacity with time after the beginning of rainfall. This method was one of the first to require the use of complicated computational procedures only made feasible by the advent of electronic computers.

Noting that storm sewered or channelized drainage ways have steeper slopes and steeper channels, Carter (1961) conducted a study on the magnitude and frequency of floods in suburban areas in the Washington, D.C. area that showed lag time to be a function of the length and slope of the 
channels in a drainage basin. In addition, he found that, "The percentage of impervious surfaces in basins in which suburban development is virtually complete is fairly low" (Carter, 1961, p. B-9) (approximately 12 percent in his study area), and that "the effect of imperviousness is small relative to other effects of suburban development on flood peaks" (Carter, 1961, p.B-10). He noted that approximately 30 percent of the rainfall on natural basins results in runoff, whereas 175 percent of the rainfall volume on impervious surfaces reaches the stream channel" (Carter, 1961, p. B-19). To show how the rainfall-runoff relationship varies between areas with different climatic regimes, Waananen (1961) summarized studies of runoff discharge, timing, and peak flow with urbanization.

In a landmark study, Harris and Rantz (1964) conducted further analysis on one of the watersheds mentioned by Waananen, located in a suburbanizing area just south of San Francisco, California. They compared the change in volume of runoff between a non-urbanized upstream portion and an urbanized downstream portion of the watershed. Over the period of the study (13 years) the impervious area in the urbanizing portion of the watershed increased from four to 19 percent, and the ratio of inflow (to the urbanized area) to outflow (from the urbanized area) increased from 1.18 to 1.70 within the 13 year period. 
Betson (1964) developed a nonlinear mathematical model to analytically equate the difference between rainfall and runoff to hydrologic variables. He used three variables, storm rainfall, duration, and soil moisture, to develop an equation that quantifies the effect of soil infiltration on the runoff characteristics of individual storms. Noting that the size of the watershed does not necessarily show a straight line relationship with the runoff response, crippen (1965) studied a smaller watershed than had been analysed in previous studies. He found that the magnitude of hydrograph changes were much smaller than the proportionatly smaller size of the watershed would suggest, and that the lag time essentially did not change at all (Fig. 4).

In 1965, James used a computer model known as the Stanford Watershed Model (based on water balance methods) to analyse a California watershed. He used a 58 year data set as a baseline to develop a long term continuous hydrograph, then varied the constants describing the changing physical conditions in the watershed to develop a set of hydrographs that reflected the different watershed characteristics. He then developed a set of curves from these hydrographs that made possible an estimate of flood peaks for any combination of percentage of area urbanized, percentage of channels improved, and stream tributary area (James, 1965).

In the midwest, Brater (1968) analysed the 


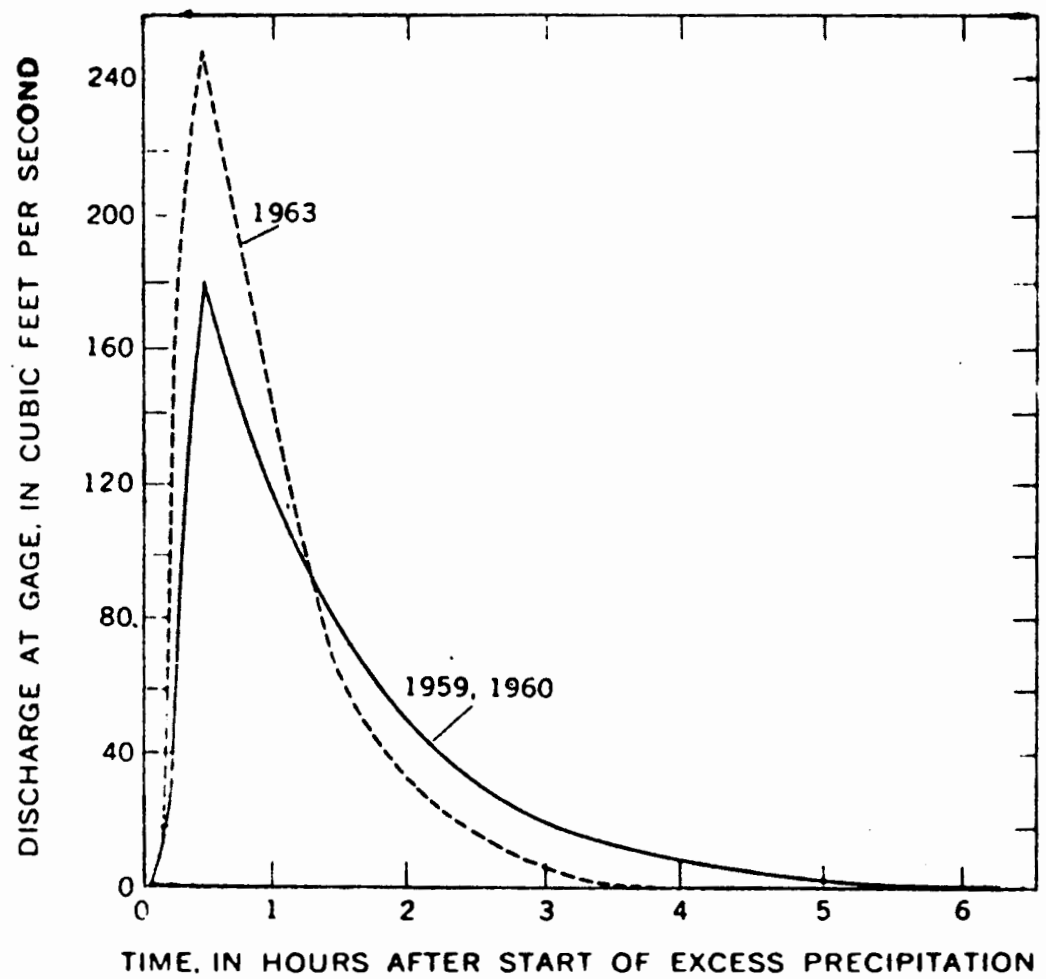

Figure 4. Average 15 Minute Hydrographs of Sharon Creek, California. (Crippen, 1965, p. D-197) 
rainfall-runoff relationships of several Detroit, Michigan, watersheds in different stages of urbanization. He analysed the initial retention, the hydrologically significant impermeable areas, and the infiltration capacities of the permeable portions of the basins. He devised a method of baseflow separation that reduced the effect of personal judgement, and related the proportion of the hydrologically significant impermeable portions of the basin to demographic variables, most notably the population density.

Martens (1968) made several pertinent observations about urbanization and flooding. He noted that, "the effect of impervious area diminishes with increased flood recurrence intervals, becoming negligible for floods having a return period exceeding 50 years. Basin lag time for fully developed basins was found to be one-fourth the lag time before development. The increase in impervious area and decrease in lag time associated with urbanization will about double the discharge of a 20-year flood" (Martens, 1968, p. C-1). He also constructed a graph that showed the variation in flood frequency ratio with percent of impervious area.

On the eastern seaboard Anderson (1968) used data from the Washington, D.C. area to construct a similar graph that showed approximately the same results. He used five independent variables: basin size, length and slope; type of 
drainage system; and the percent of impervious area. A relevant finding was that improvements to. the drainage system could reduce lag time to one-eighth that of natural channels.

- At Long Island, New York, Seaburn (1969) did a study that related "indices of urban development to increases in the volume of annual direct runoff to the stream, compared hydrograph features at different periods during the transition of the drainage basin from rural to urban conditions, and compared the rainfall-runoff relations for periods before and after urban development" (Seaburn, 1969, p. B-1). His results showed that from 1943 to 1962 the land served by storm sewers increased by about 530 percent and the average annual direct runoff increased by about 270 percent. Roberts and Klingeman (1970) constructed a scale model of a watershed to model the effects of variations in rainfall intensity, rainfall duration, storm movement, simulated permeability and antecedent moisture conditions on the shape of outflow hydrographs. Each parameter was found to have a significant effect on the resultant discharge hydrograph shape.

Water Quality

With respect to non-point source water pollution urbanization affects water quality in two ways. There is an 
increase in the amount of unnatural substances released into the environment, and the increased covering of the natural soil surface by impervious materials tends to help flush the unnatural substances directly into the stream system rather than filtering them through the soil.

As summarized by Lazaro (1979), the major pollutants that enter waterways as a result of urbanization are: lead, rubber compounds, oils and high chemical oxygen demand pollutants, all from automobiles; high turbidity and sediment concentrations from construction activities; chlorides from street salting; nitrates and phosphates resulting in high biological oxygen demand (BOD) trom urban litter; water temperature increases and decreases during the summer and winter, respectively, from clearing natural vegetation from the stream channel; high BOD from organic material stagnating in the stream bed in the summer, caused by low flows and channel restrictions; and phosporous and bacterial contamination from subsurface sewage disposal. Because many of these pollutants are stored on the ground surface during dry periods, a rain will flush them out all at once, resulting in a high pollutant concentration for a short time that corresponds with the hydrograph rise. Urbanization results in low dry season baseflows and water quality declines because the pollutants are more concentrated. 
THESIS AREA STUDIES

\section{$\underline{\text { Runoff }}$}

A number of researchers have studied the Johnson Creek watershed in an attempt to identify and mitigate problems resulting from urbanization. The CRAG (1971) produced a drainage plan for the Portland metropolitan area in which they addressed "drainage basin environmental characteristics, surface runoff analyses, existing storm drainage studies, and economic studies" (CRAG, 1971, p. 1). Appendix II of the addendum to this report included a section on the Johnson Creek drainage basin (including that portion below the sycamore gage). This appendix covered a basin description and history; "1964 flood plain land assessment information; critical hydraulic data; area maps and pictures; status of Corps of Enginneers and Soil Conservation Service studies; recommendations for consultant attorney and CRAG's staff; and 1972-1973 work programs concerning Johnson Creek" (CRAG 1971, p. 47).

The Corps of Engineers (1975) updated a 1958 design memorandum for flood control works in the Johnson Creek basin (including below the sycamore gage). The report details a proposed structural engineering solution to the flooding problems, and includes an economic base study, an analysis of the cost-benefit ratio, population projections, 
a detailed description of the proposed engineering works, and an iteration of the geologic description by Hogenson and Foxworthy (1964).

The Metropolitan Service District (MSD) presented an all-encompassing study of "Drainage Management in the Johnson Creek Basin" in which they describe the basin, summarize the proposed technical solutions, and discuss possible methods of funding the improvements. The report also details the efforts of the MSD to get the public involved in the responsibility and planning for flood control efforts.

In an attempt to estimate peak discharges and storm runoff volumes, Laenen (1980) used data from 24 streamflow gaging stations in the Portland metropolitan area to develop a set of regression equations that take into account various basin characteristics. The indices that were found to be the most significant were drainage area, effective impervious area, storage, rainfall intensity, basin slope, and soil infiltration. His equations indicate that runoff volumes could more than triple with total urbanization, and peak discharges could double.

Seltzer (1983) used the Johnson Creek watershed (including below the sycamore gage) as an example in his dissertation on "Citizen Participation in Environmental planning..", and included a basin physical description, 
history of flood control agencies and their efforts, and a study of the population growth within the basin.

\section{Water Quality}

The water quality in Johnson Creek has been studied several times (State of Oregon 1975, Metro, 1981), and the findings have shown that the two seasonal regimes (summer low flows and winter high flows) result in different water quality regimes. The summer low flows result in higher water temperatures, and when mixed with decomposing organics in stagnant pools and nitrate and phosporous loading from subsurface sewers result in the growth of algal blooms and high fecal coliform concentrations. The first winter rains flush high concentrations of nitrates (from fertilizers) and oil, grease and lead (from pavement runoff) into the stream system. 


\section{CHAPTER III}

THE JOHNSON CREEK WATERSHED

CLIMATE

The Johnson Creek watershed is located between the Coast range and the Cascade range, and as a result is somewhat protected from the humid marine airmasses coming from the west, and well protected from the dry continental airmasses to the east. The winter weather pattern is dominated by moisture laden, cyclonic low pressure air masses approaching from the southwest, although the continental high pressure air masses occasionally break through from the east and bring clear, dry, freezing weather into the watershed area. During the summer season an arm of the North Pacific high pressure cell extends farther northward (Fig. 5), and in conjunction with the cool coastal waters results in a significant lack of precipitation (Fig. 6) (Johnson and Dart, 1982). Fall and spring climates are transitional between the summer and winter climates. 


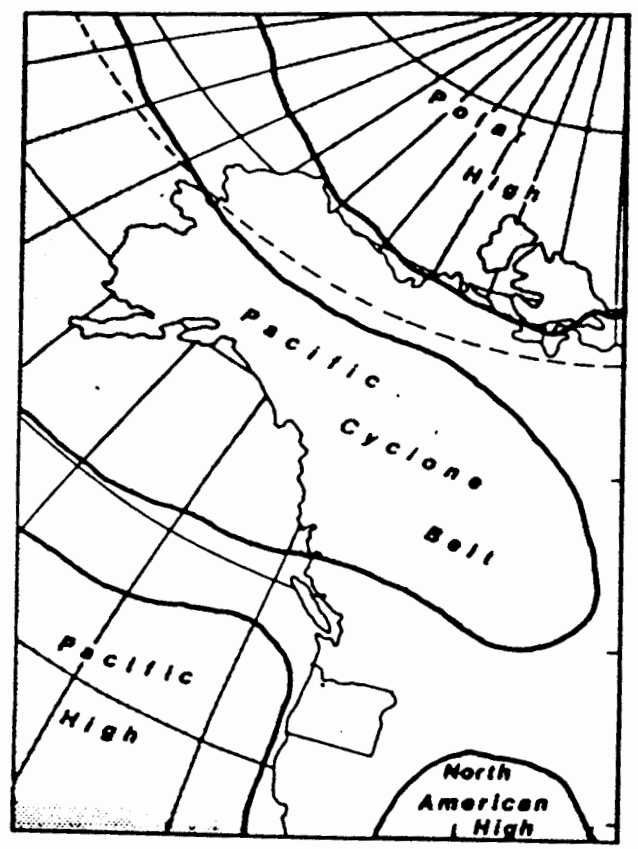

Predominant Summer Weather Regimes

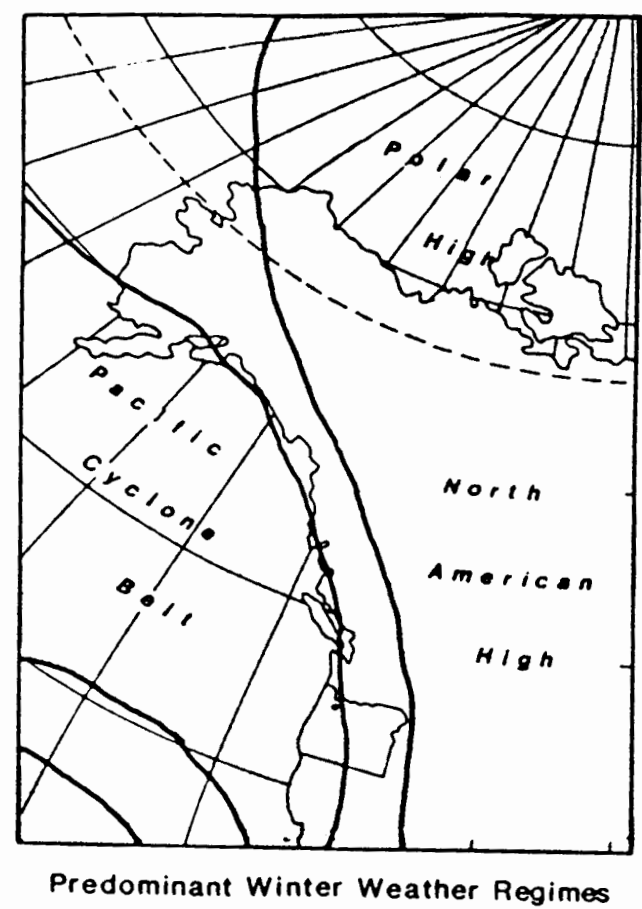

Predominant Winter Weather Regimes

Figure 5. Predominant Summer and Winter Weather Regimes (Chow, 1964, pp. 3-37 \& 3-38) 


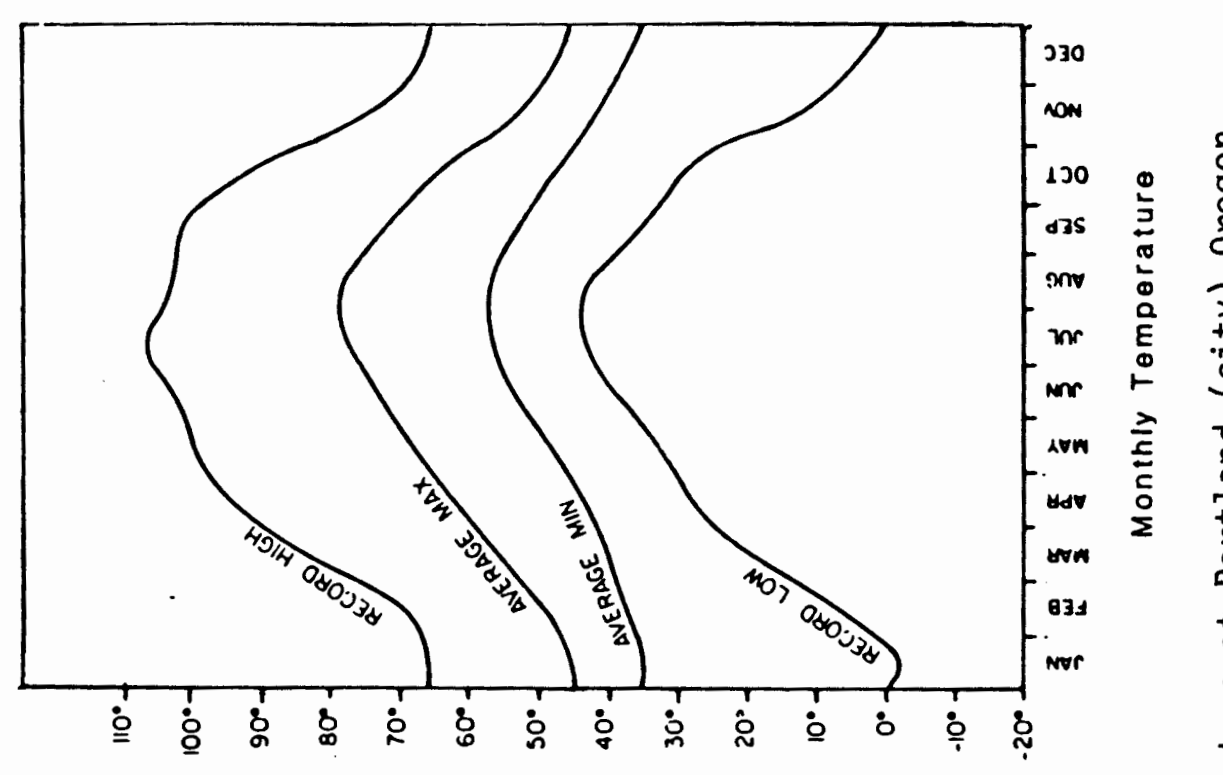

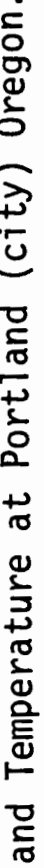

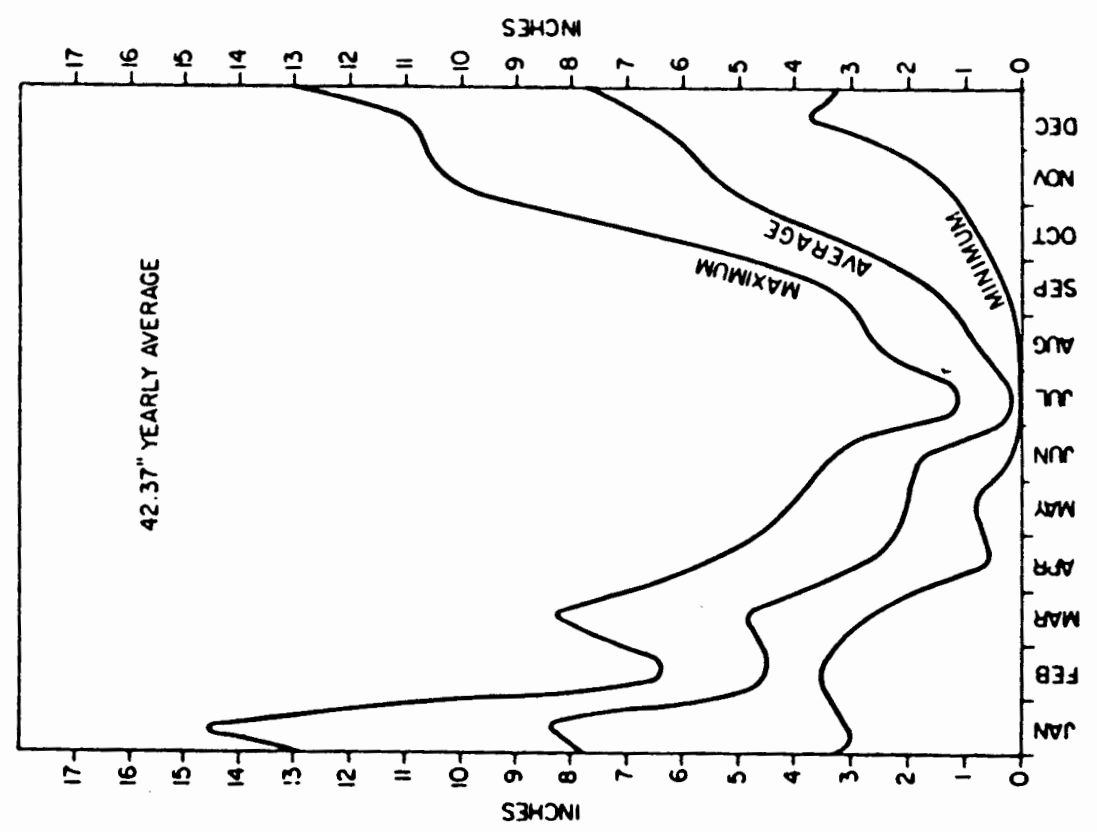

.

츠

ब․

ฉ。

을

흐

ํㅡㄹ

$\overline{0} 0$ र

잉

\%

这容

ह

웅

원 
between the beginning of October and the end of May, with the highest amount falling during December (Fig. 6). The average annual precipitation in the upper basin is 53 inches, ranging from 44 inches at the gaging station to $7 \varnothing$ inches at the eastern end of the watershed (Fig. 7) (Corps of Engineers, 1977). This increase in precipitation upstream is caused by orographic effects, as there is a 536 foot increase in elevation from the gaging station in the west to the end of the watershed in the east, and the foothills of the Cascade mountains begin less than one mile from the eastern end of the watershed. The year to year range of annual precipitation in the area is great, varying from 26 to 67 inches (Fig. 8).

A plot of the monthly coefficients of variation shows the least amount of interannual variation during the months with the largest amount of precipitation (Fig. 9).

Johnson and Dart (1982) analysed precipitation variability in the Pacific Northwest and made several observations about the annual rainfall series in western Oregon:

1. Rapid oscillations from year to year(fig. 10)

2. Very few groupings of unusually wet or dry years

3. An increasing trend from the early 1930's to the early or mid 1970's (fig. 9)

Rainfall intensity-duration-frequency curves for 


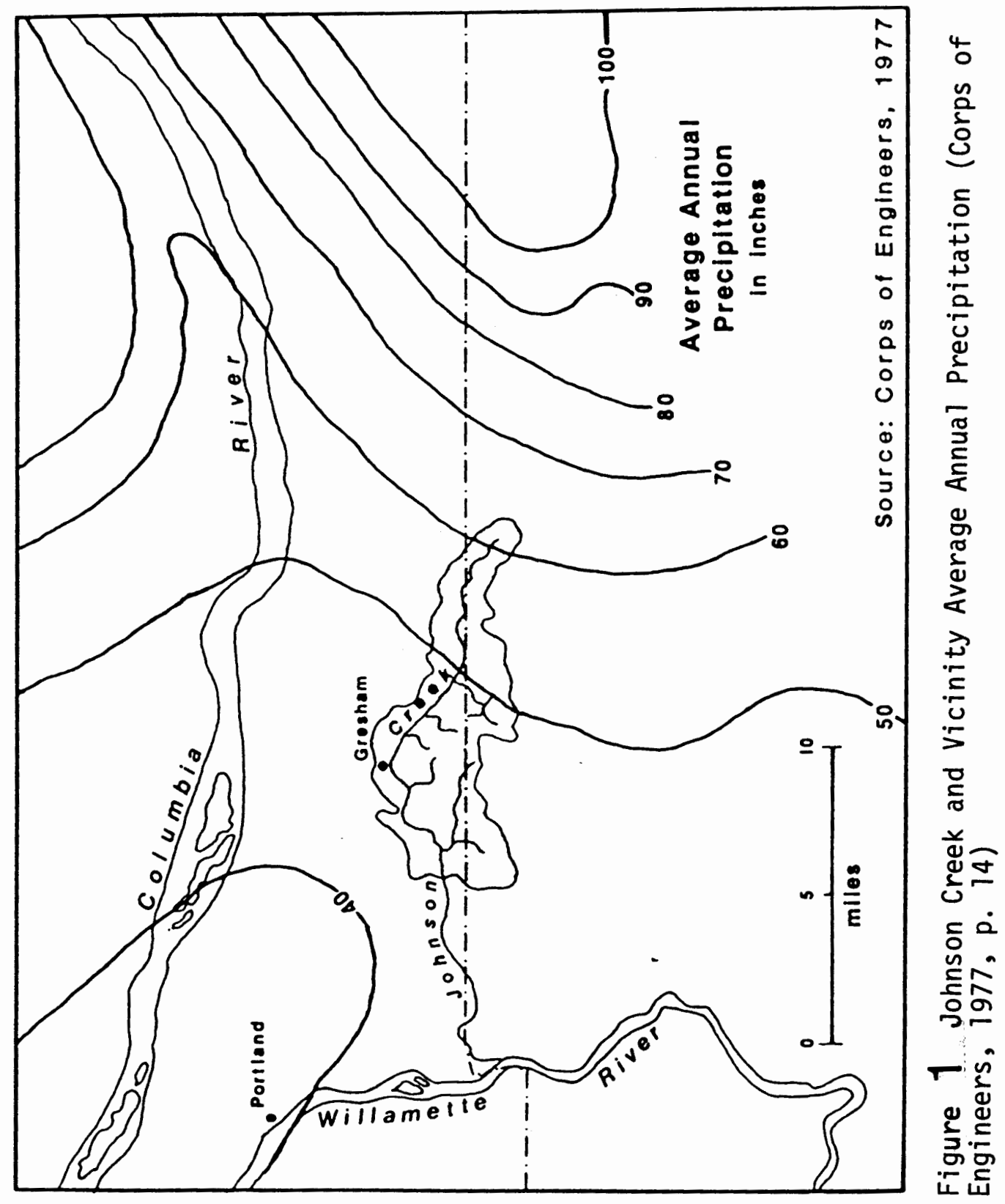




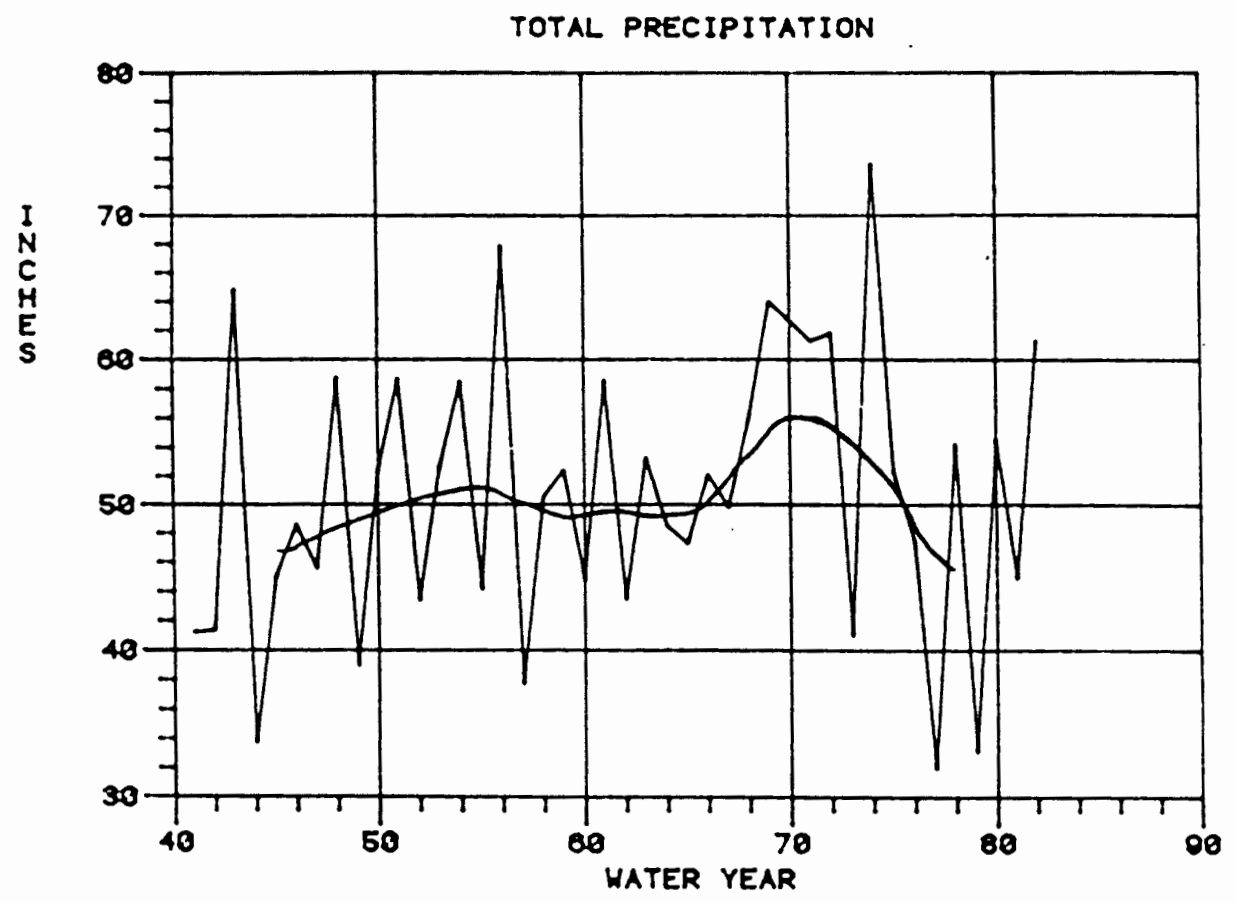

Figure 8. Portland (city) Average Annual Precipitation (19411982) 


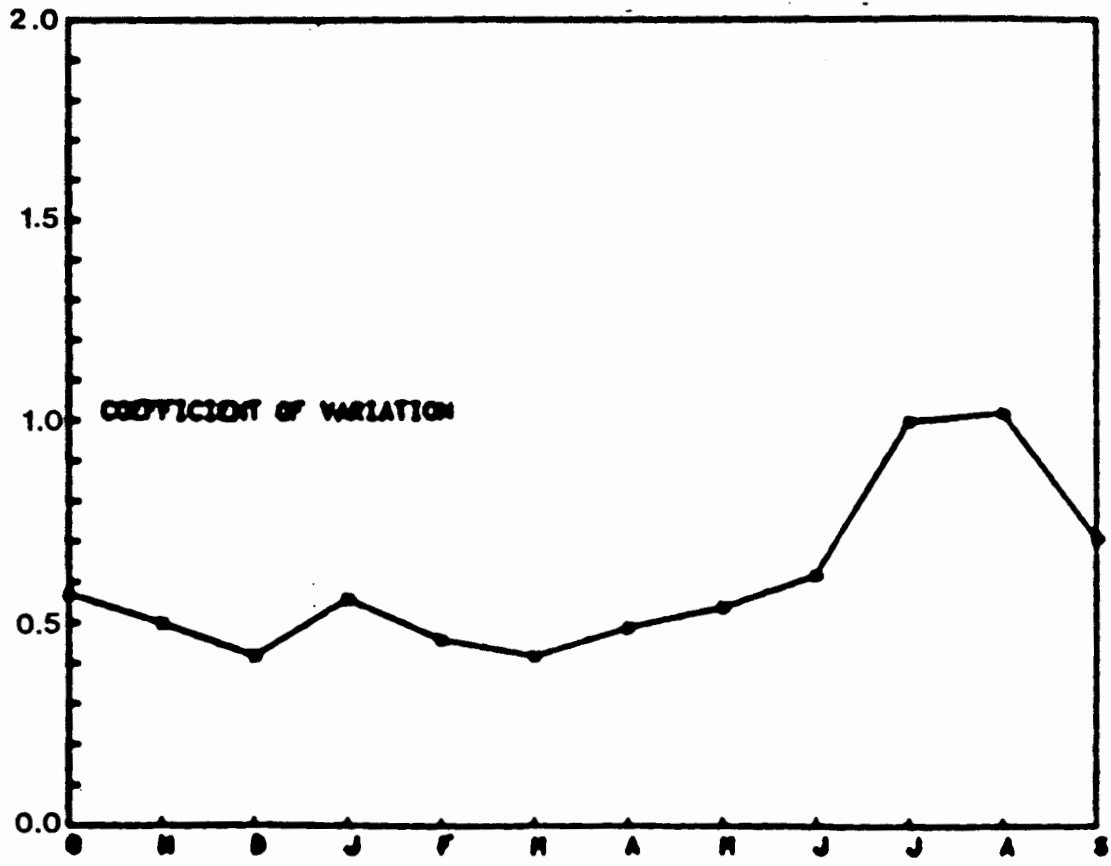

Figure 9. Portland (city) Coeffecient of Variation (Johnson and Dart, 1982, p. 89) 


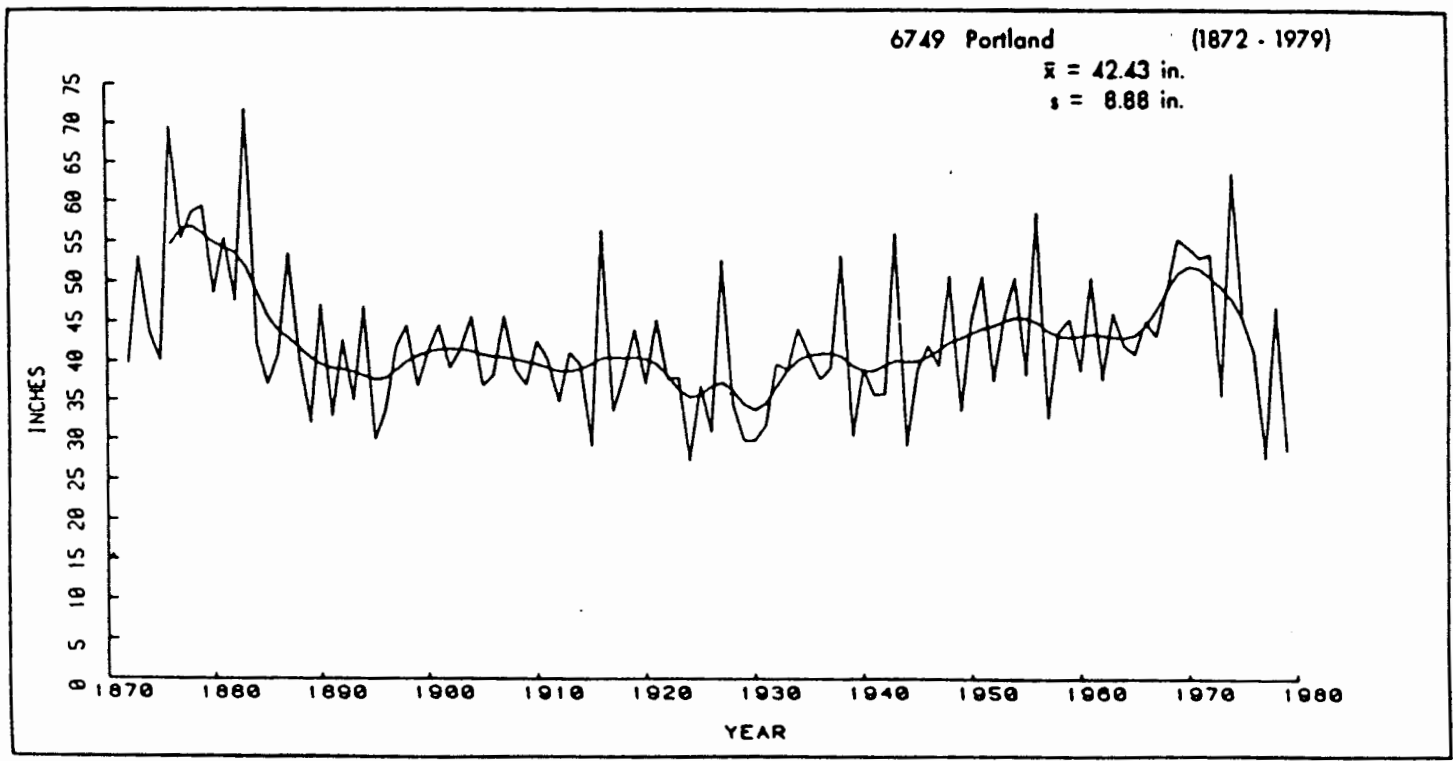

Figure 10. Portland (city) Average Annual Precipitation (1872-1979) (Johnson and Dart,1982, p. E-17) 
Portland, Oregon (city) are depicted in Figure 11. Rainfall intensities associated with the winter cyclonic storms are usually low, and the seemingly continuous drizzle is characteristic of the western oregon climate. These low rainfall intensities result in less direct runoff than in areas where convective precipitation predominates, as the rainfall has more time to infiltrate.

Hailstorms are not uncommon in the summer, and freezing rain is often associated with the wintertime surges of continental air. Snowfall in the Johnson Creek basin averages about 8.4 inches per year, falls for an average of only five days per year, and rarely stays on the ground for more than a few days. These averages are misleading, as many years have had little if any snowfall and others have had voluminous amounts. The greatest 24 hour snowfall was 15 inches, and the largest amount of snowfall in one month was 35.3 inches (since 1871) (Corps of Engineers, 1975). It should be noted that snowmelt is not a contributing factor to flooding problems in this watershed.

The relative humidity is moderately high, ranging from 90 percent $(+/-)$ at four AM (year around) to about 70 percent at four PM from November through February and often less than 50 percent the rest of the year (Hogenson and Foxworthy, 1965). Heavy fog occurs on an average of 33 days per year, and an average of 228 days per year are cloudy 


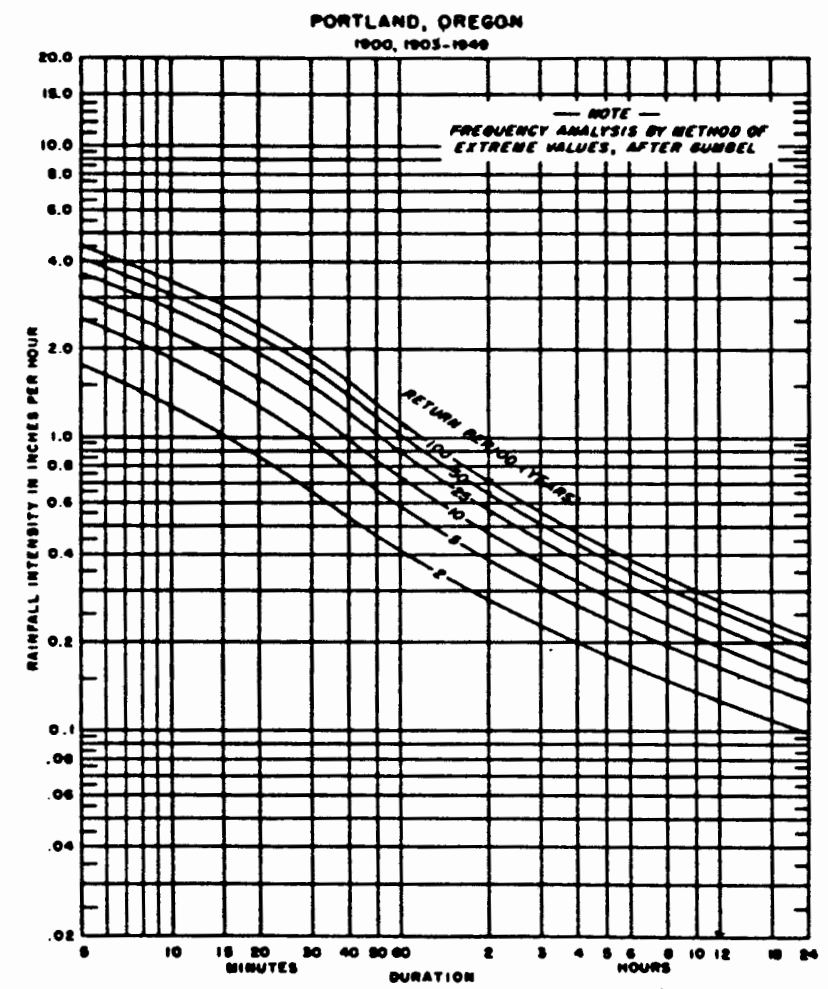

Figure 11. Portland (city) Intensity-Duration-Frequency Curves (U.S. Weather Bureau, 1955, p. 37) 
(most of them in the winter months) (NOAA, 1983).

Winds are consistent and gentle. The average monthly mean wind speed ranges from $6.4 \mathrm{mph}$ in September and october to $10.1 \mathrm{mph}$ in January, although the highest wind speed of record was $88 \mathrm{mph}$. The prevailing surface wind direction is from the northwest from April to september and and from the east-southeast from October to March (NOAA, 1983).

Temperatures have ranged from a low of $-3^{\circ} \mathrm{F}$ to a high of $107^{\circ} \mathrm{F}$, a relatively modest range in comparison with the rest of the nation. The average daily maximum temperature ranges from $43.60 \mathrm{~F}$ in January to $79.00 \mathrm{~F}$ in July, and the average daily minimum ranges from $32.5^{\circ} \mathrm{F}$ to $55.2^{\circ} \mathrm{F}$, respectively (Fig. 6). On the average only 27 days a year experience temperatures below freezing (NOAA, 1983).

\section{LANDFORMS}

$\underline{\text { Geology }}$

Johnson Creek is located in the willamette Valley, a major geomorphic anticline that is known as the willamette Trough. The Johnson Creek drainage basin is geologically very recent, although it is underlain by much older rocks. The whole area is underlain by layers of the Columbia River Basalts (Fig. 12). Above these lie a younger, impervious 


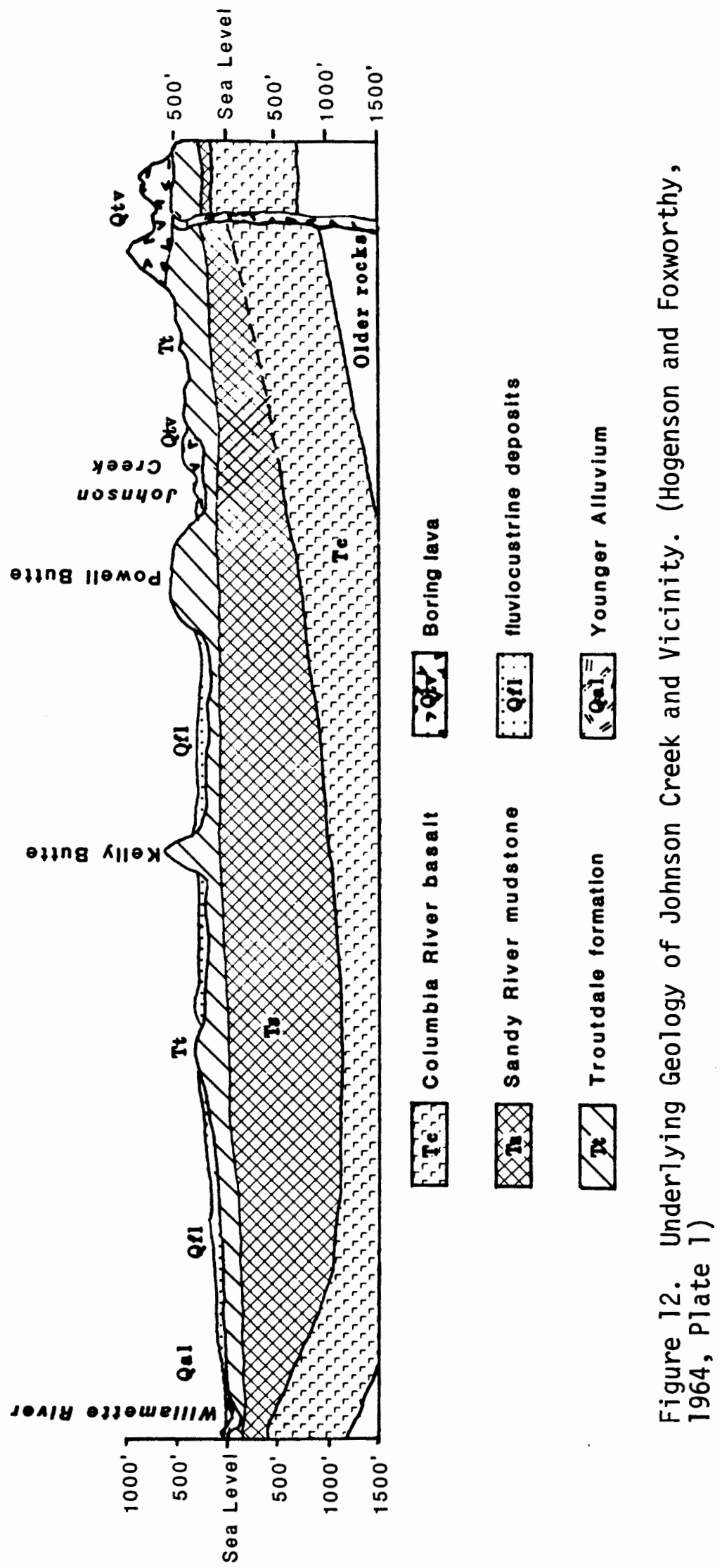


layer of mudstone and claystone that is known as the Sandy River Mudstone. A Metropolitan Service District report (METRO 1975) points out that as it is probably of lacustrine origin and although is is not exposed in the basin, it is important as it is the lower limit of groundwater percolation. The next higher geologic unit is the Troutdale Formation, composed of a concordant series of conglomerate, gravel, clay and sand. It is of fluvial origin, contains most of the regional groundwater, and lies at an average depth of 300 to 600 feet.

Surficial Topography

The watershed is composed of three easily definable geomorphic subareas, the Boring Hills, the Kelso slope, and the Portland Terraces (Fig. 13). After the Troutdale Formation was laid down, a series of volcanic extrusions composed of both basalts and pyroclastic debris covered parts of the southern half of the basin. Where exposed these are known as the Boring Hills, and occupy approximately 61 percent $\left(18.3 \mathrm{mi}^{2}\right)$ of the watershed. They are an area "...of rolling hills... buttes and associated benches and highlands. The individual hills are mostly steep sided and conical or dome shaped, although some have relatively flat or rounded tops" (Hogenson, 1965). The buttes project up to 900 feet above the valley bottoms and 


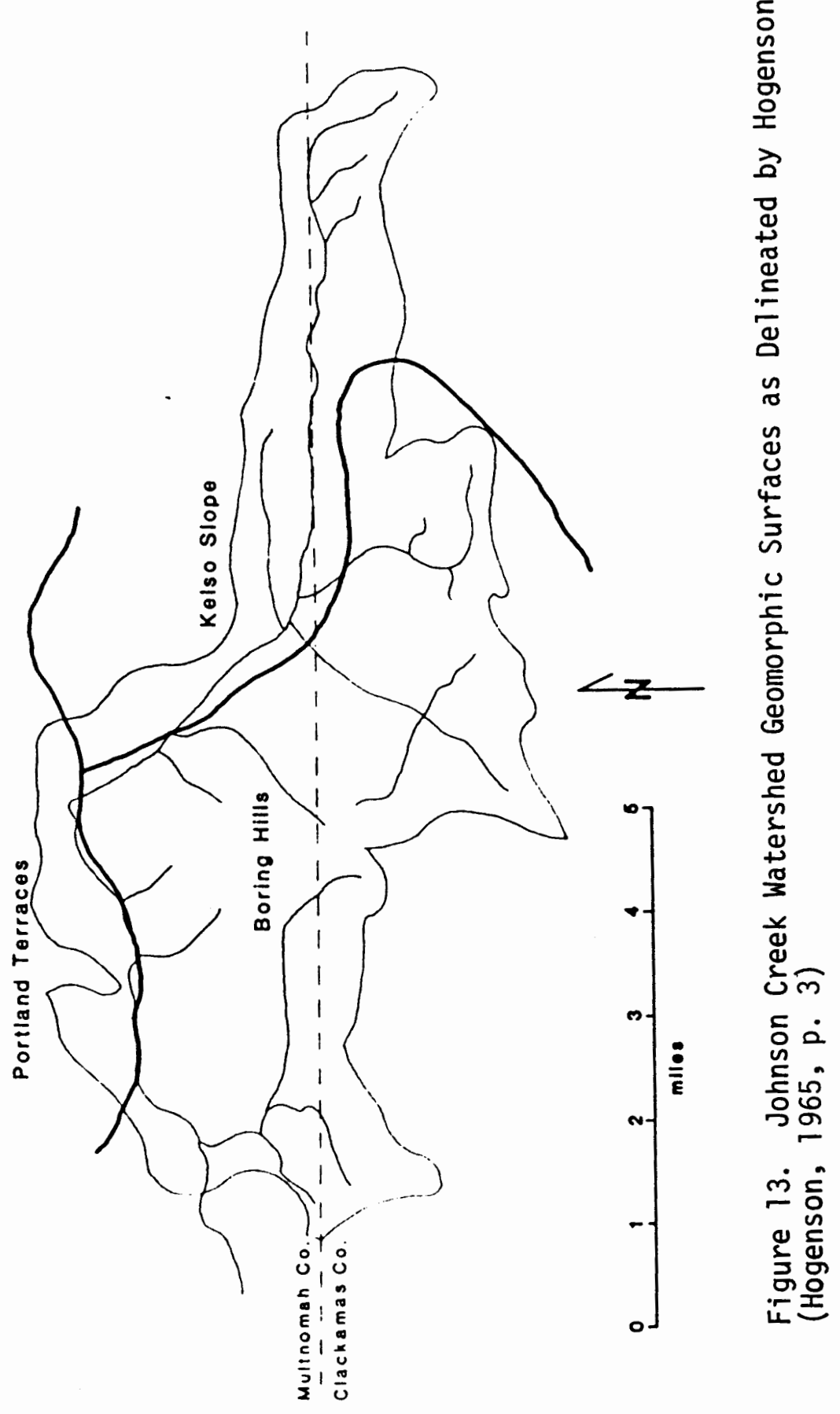


much of them are composed of slopes in excess of 20 percent (Fig. 14).

The Soil Conservation Service (SCS) makes a different classification of geomorphic surfaces (Fig. 15). The boundaries of the SCS geomorphic surfaces roughly correspond with those of Hogenson. The SCS describes the characteristics of the soils that underlie the different surfaces. The surfaces found in the Boring Hills are the Eola, the Looney, and the Dolf geomorphic units. The Eola unit (eo) is the oldest stable unit, formed in the early Pleistocene (and all but removed by late pleistocene and Holocene erosion) and its elevation (600 feet above sea level (asl)) corresponds with the top of the hills. The Looney unit (10) is usually a steep slope of transition between the Eola unit and lower elevation surfaces. The Dolf unit(do) ranging from 450 to 600 feet asl is probably middle pleistocene in age, and is less steep than the Looney unit.

In the Kelso Slope area piedmont deposits of the late Pleistocene overlie the the Troutdale Formation and the Boring lavas, and are made up of fluvial and mudflow deposits. This area occupies approximately 28 percent 17.4 $\mathrm{mi}^{2}$ ) of the watershed and is a "dissected northwestward sloping surface" (Hogenson, 1965). The larger valley areas between the Boring Hills (Sunshine valley and Pleasant 


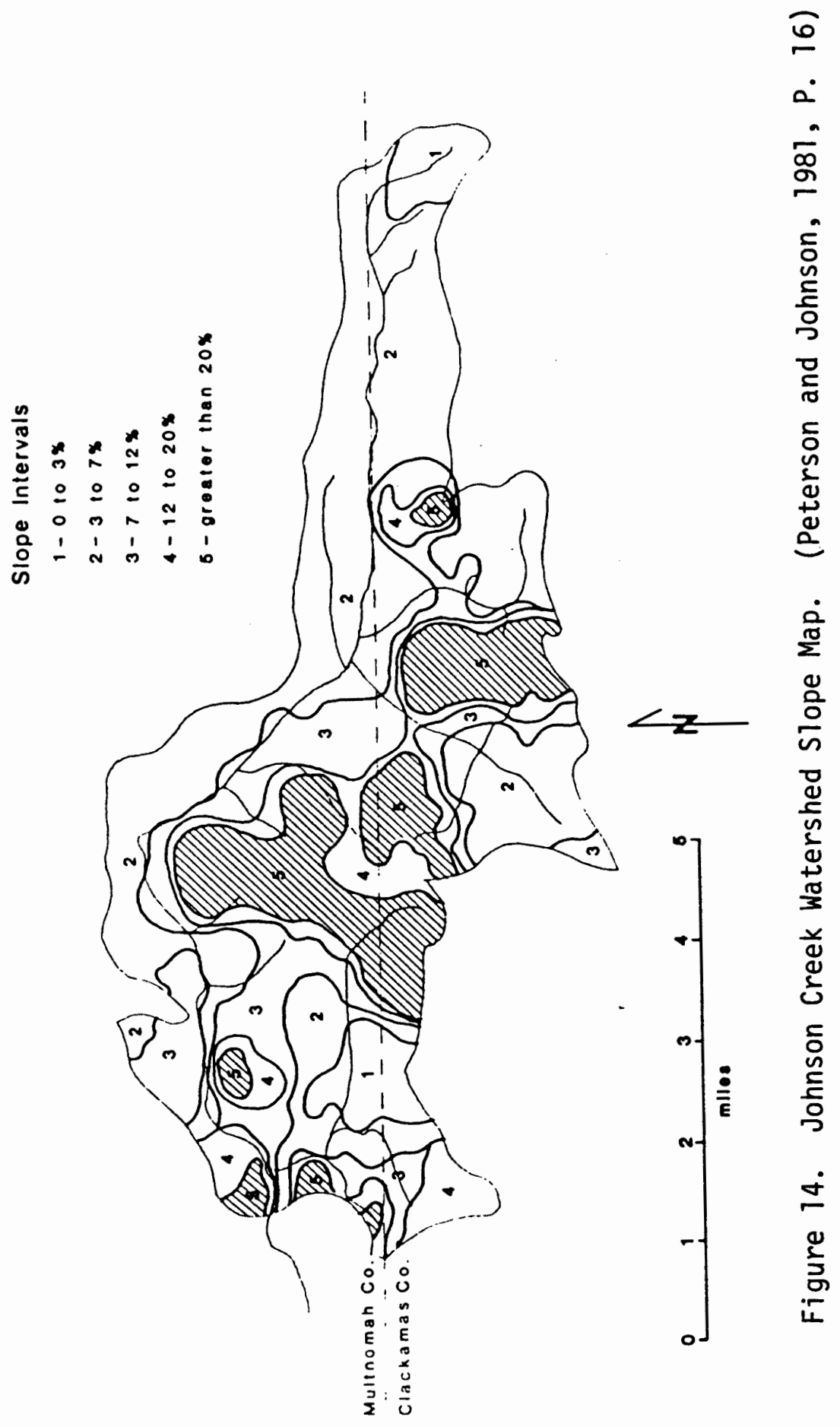




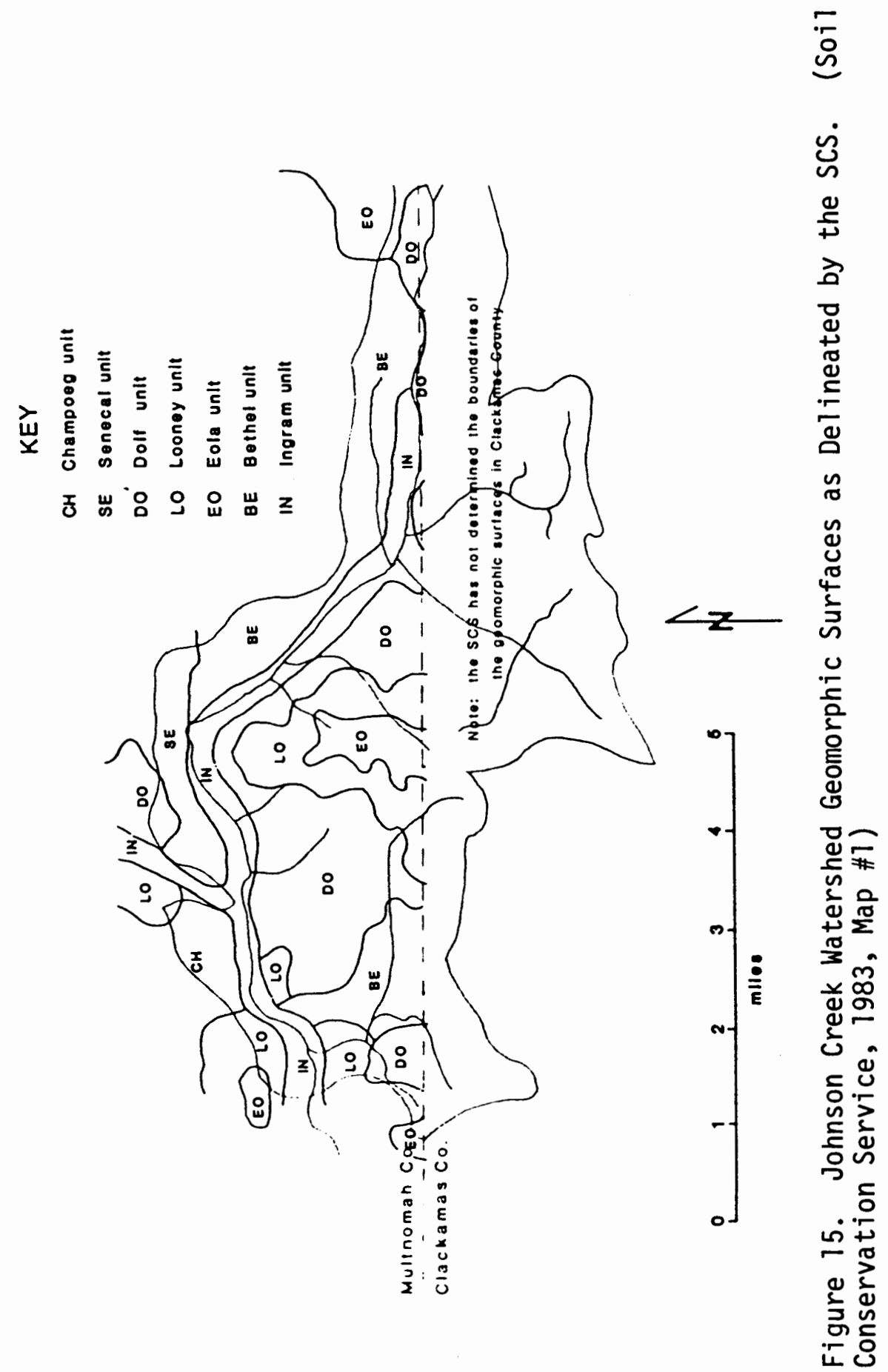


Valley) are geomorphically similar to the Kelso slope, and as the elevations are somewhat concordant and the underlying alluvium is the same, Hogenson (1965) believes they were formed by the same geomorphic processes. The scs classifies the Kelso Slope as the Bethel surface (be). In the Johnson Creek watershed these slopes are a vertical transition between the Dolf surface above and the Senecal (se) surface below, ranging from 300 to 500 feet asl. This surface contains most of the ice rafted glacial erratics brought down the Columbia River by the Missoula Floods.

The Portland Terraces occupy approximately 11 percent (2.9 $\mathrm{mi}^{2}$ ) of the watershed. This area, although the smallest in area of the geomorphic sub-areas, is at least as significant as the others, as the City of Gresham almost wholly covers it. The scs classifies the portions of the Portland Terraces that lie within the Johnson Creek watershed as the Senecal and Champoeg (ch) surfaces. The

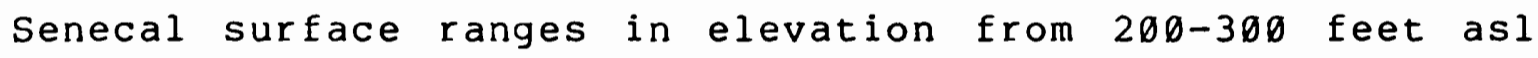
and consists of older river terrace remnants. The Champoeg surface ranges from 150-250 feet asl, was shaped by the Missoula Floods, and alluvium from the flood outwash is common.

A profile of river gradients is depicted in Fig. 16, and other drainage basin morphometric characteristics have been calculated by Laenen (1980) and are presented in Table I. 


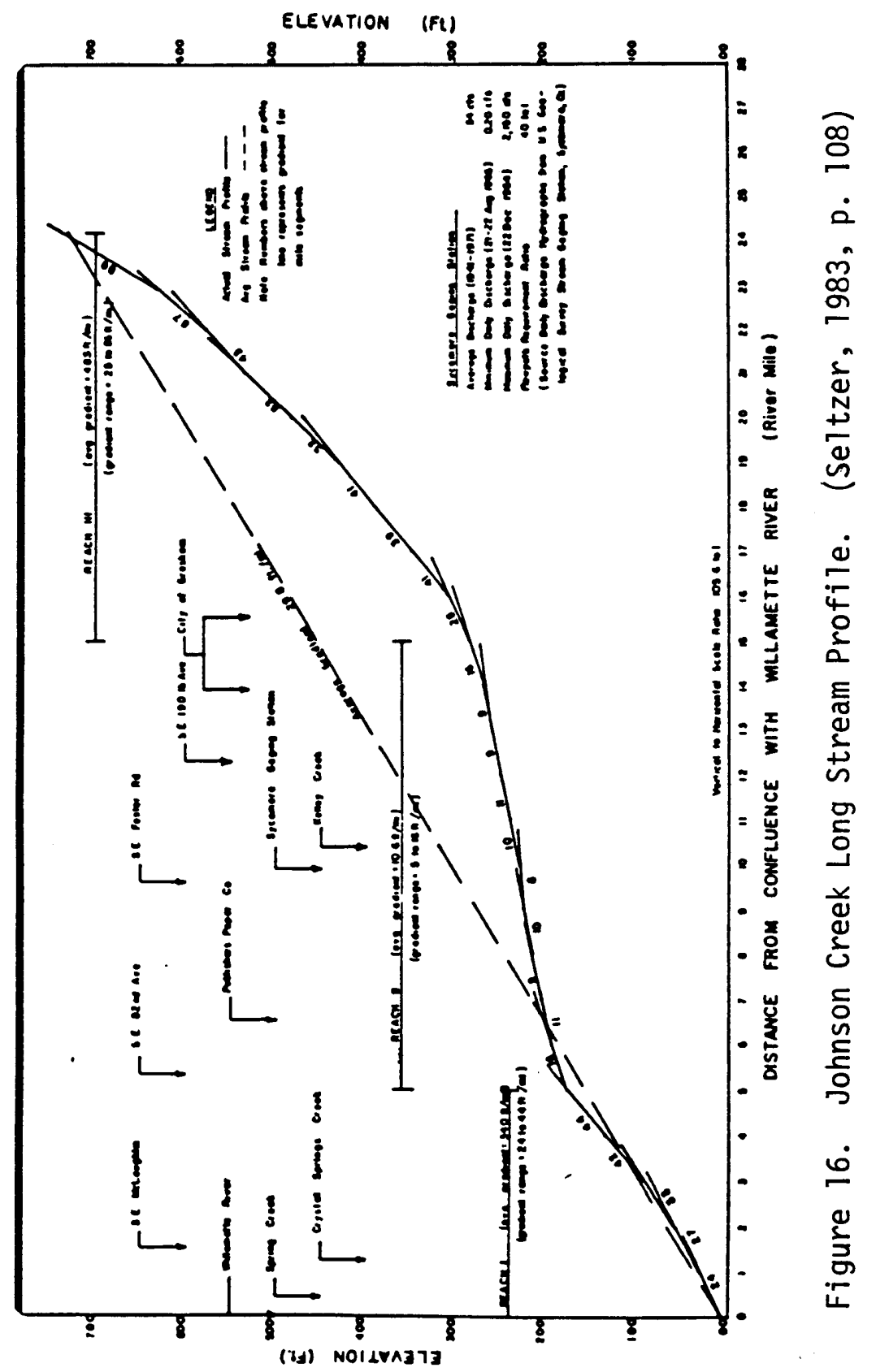




\section{TABLE 1}

JOHNSON CREEK WATERSHED PHYSICAL CHARACTERISTICS

Drainage Area:

Main Channel Length:

Basin Shape:

Channel Slope:

Sewered Area:

Average Gutter Length:

Effective Impervious Area:

Average Annual Precip.:

Precip. Adjustment:

Concentration Time:

Average Lag Time:

Average Basin Slope:

Storage Area:

Land Use Types:

A. Parks, Forest, Vacant Land 358

B. Agriculture

C. Light to Normal Residential

D. Dense Residential

E. Apartments and Commercial 18

128

18
$26.5 \mathrm{Mi}^{2}$

$13.8 \mathrm{Mi}$

4.73 (1)

$32 \mathrm{Ft} / \mathrm{Mi}(2)$

3.48

$1.1 \mathrm{Mi} / \mathrm{Mi}^{2}$

78

53 In

1.16 (3)

10 Hrs

25 Hrs (4)

$580 \mathrm{Ft} / \mathrm{Mi}$

0.38

Notes:

(1) Basin Length Divided by Drainage Area

(2) 10 and 258 of Distance Along Channel

(3) Precipitation Increase: Portland City to Gresham

(4) Center of Mass of Precipitation to Center of Mass of Hydrograph

Source: Laenen, 1980 
SOILS

Most of the soils in the Johnson Creek watershed (Fig. 17) are recent, due to the scouring action of the Missoula Flood waters. The oldest soils are in the extreme eastern end of the watershed, and on the hill tops. Most lower elevation soils are formed on alluvium, and are partially composed of loess and volcanic ash. The majority of the soils in the watershed are underlain by a fragipan (Table II), have a perched water table, and as a result are poorly suited for homesites or farming (Green, 1983). An analysis of Table II will shed some insight into the soil properties that are relevant to the hydrologic response of the watershed.

As hydrologic soil groups are an important indication of the effect of soils on runoff potential, Table III is provided to give a description of the various hydrologic soil groups found in the watershed. Within the drainage basin, 85 percent of the soils are in hydrologic soil group ' $C$ ', and most of the urbanization has occured on these soils. They have a moderately high runoff potential and slow infiltration rates. Eight percent of the watershed is underlain by the Wapato silt Loam (hydrologic soil group 'D') which is a soil with high runoff potential and very slow infiltration rates. 


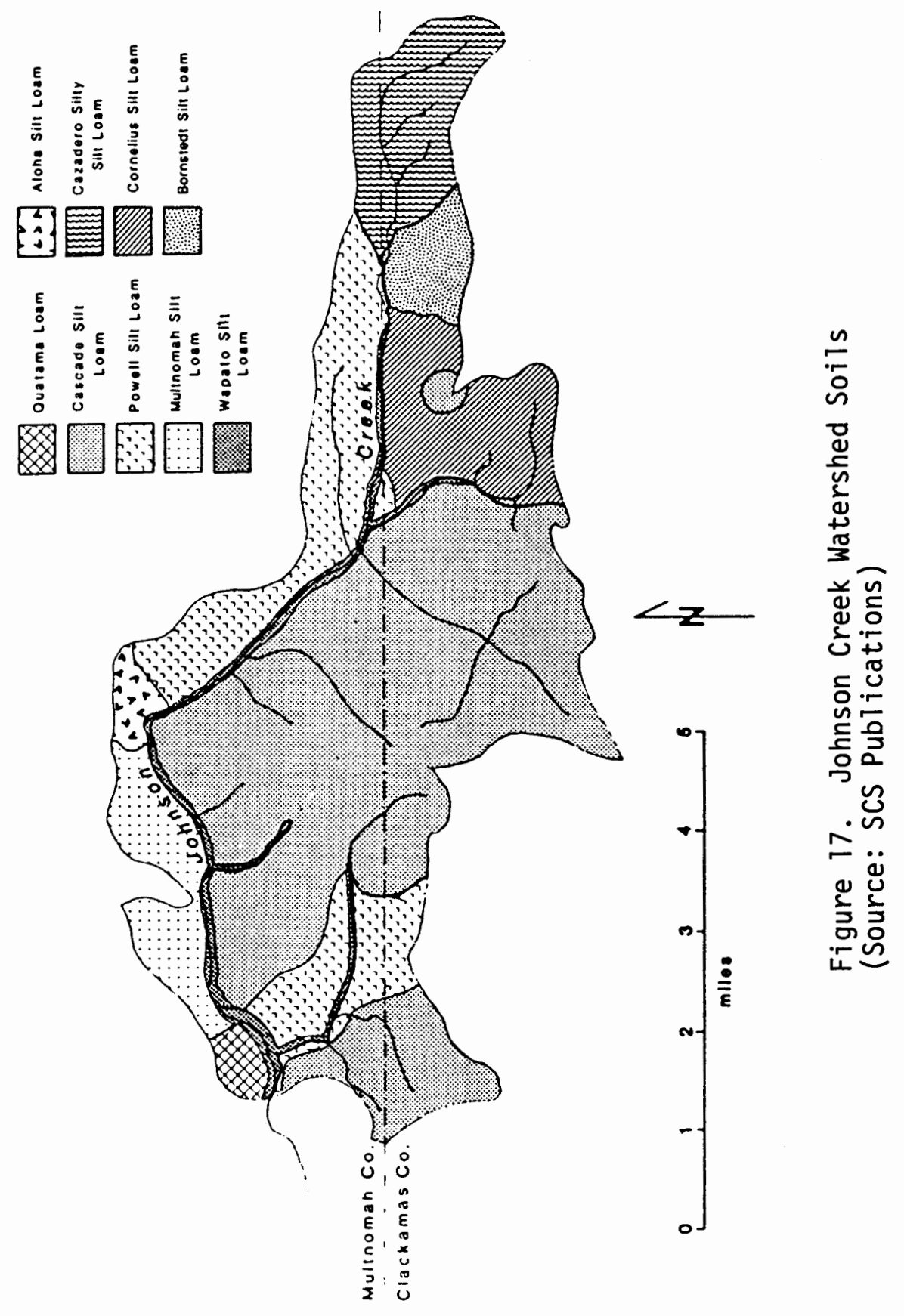




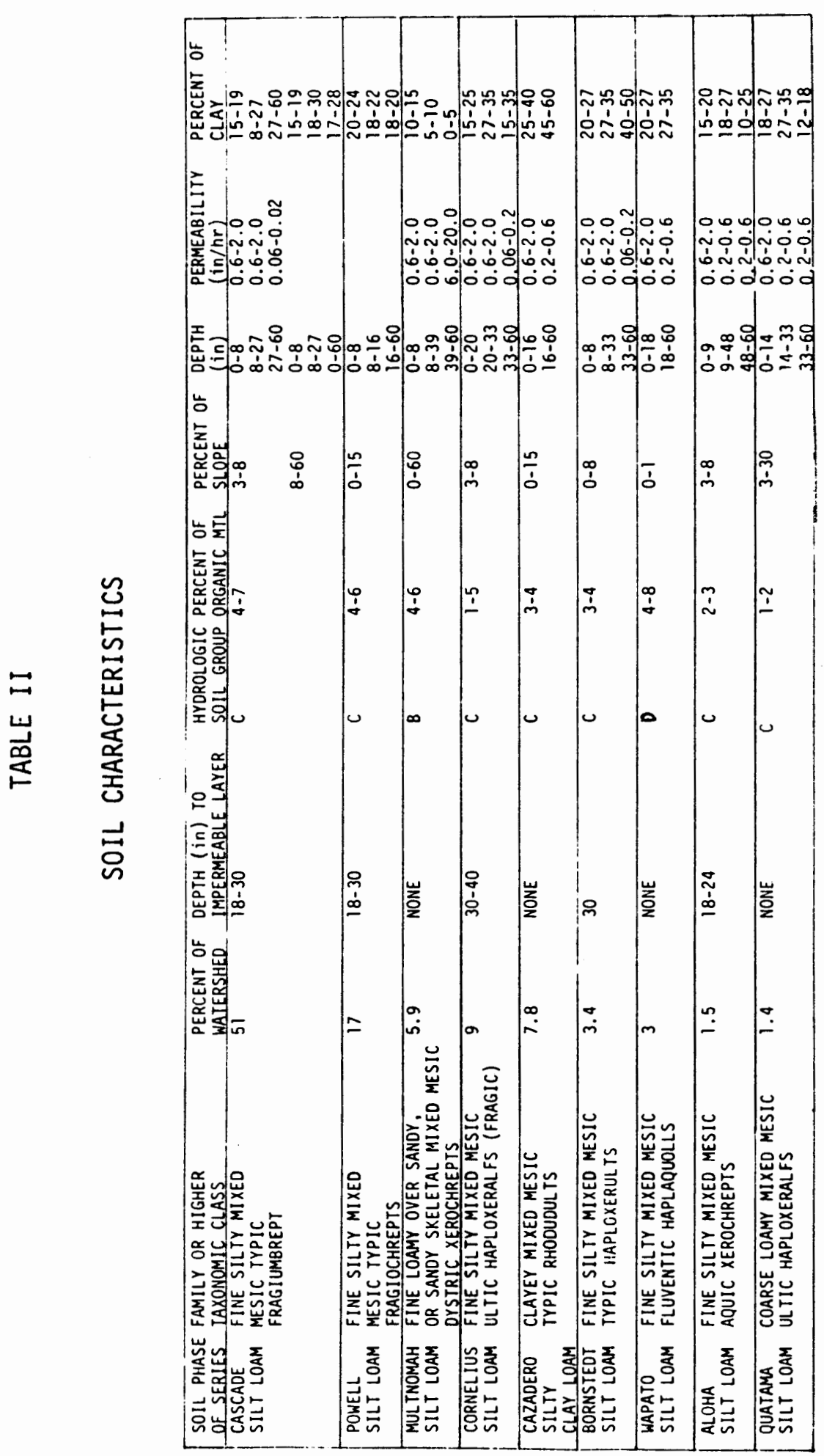


TABLE III

\section{HYDROLOGIC SOIL GROUPS}

Hydrologic soil groups are used to estimate runoff from rainfall. Soil properties are considered that influence the minimum rate of infiltration obtained for a bare soil after prolonged wetting. These properties are: depth of seasonally high water table, intake rate and permeability after prolonged wetting, and depth to a very slowly permeable layer. The influence of ground cover is treated independently--not in hydrologic soil groups.

HYDROLOGIC SOIL GROUP 'C'

...moderately high runoff potential and slow infiltration rates when thorougly wetted. They consist chiefly of soils with a layer that impedes downward movement of water, soils with moderately fine to fine texture, ...or soils with moderate seasonal water tables. These soils may be somewhat poorly drained. They include well and moderately drained soils with slowly and very slowly permeable layers such as fragipans, hardpans, hard bedrock and the like at depths of 20 to 40 inches. These soils have a slow rate of water transmission.

HYDROLOGIC SOIL GROUP ' $D$ '

...high runoff potential and very slow infiltration rates when thoroughly wetted. They consist chiefly of clay soils with a high swelling potential, soils with a permanent high water table, soils with a claypan or clay layer near the surface,... and shallow soils over nearly impervious material. These soils have a very slow rate of water transmission.

HYDROLOGIC SOIL GROUP 'B'

...moderately low runoff potential and moderate infiltration rates when thoroughly wetted. They consist chiefly of moderately deep to deep, moderately to well drained soils with moderately fine to moderately coarse textures and moderately slow to moderately rapid permeability. These soils have a moderate rate of water transmission.

SOURCE : SCS, 1983, pp. 8-9 
The soil is found only in floodplain areas and as a result is not very urbanized. Seven percent of the watershed is underlain by the Multnomah silt Loam (hydrologic soil group 'B'), a soil with moderately low runoff potential and moderate infiltration rates. The western portion of the city of Gresham is located on this soil.

The impact of urbanization varies with the soil type and the way in which the urbanized area is drained. In the areas underlain by soils with a high runoff potential (hydrologic soil groups $C$ and D), an urbanized area drained into storm sewers thence directly into a waterway will not change the basin output as much as a similarly drained urbanized area over a more permeable soil. Hence the area of Gresham underlain by the Multnomah Silt Loam (hydrologic soil group C) will affect the basin output more than a similarly drained urbanized area in the rest of the watershed. The properties of the various soil groups are also apparent in Table II in the columns denoting depth to impermeable layer, percent of organic matter, permeability rate, and clay content.

FLORA

The humid climate of this area results in a dense 
natural vegetal cover. The original vegetation in the lowlands is thought to have been oregon white Oak (Quercus garryana), and open grasslands, grading into Douglas Fir (Pseudotsuga menziesii) and Western Hemlock (Tsuga hetrophylla) in the wetter eastern reaches of the watershed. With increasing cultivation, the natural vegetation is confined to steep slopes and seasonally flooded riparian areas, although in the Gresham area most of the riparian vegetation has been altered or removed (City of Gresham, 1980). The major species include Red Alder (Alnus rubra), Bigleaf Maple (Acer macrophylla), Western Redcedar (Thuja plicata), Douglas Fir (Pseudotsuga menziesii), and Western Hemlock (Tsuga hetrophylla), with willow (Salix spp.) and Black Cottonwood (Populus trichocarpa) in the lowlands (City of Gresham 1980; Price, 1971). Minor species include Vine Maple (Acer circinatum), Oregon Grape (Berberis nervosa), Salal (Gaultheria shalon), Pacific Dogwood (Cornus nuttallii), Common Snowberry (Symphoricarpos albus), Trailing Blackberry (Rubus ursinus), Roses (Rosa spp.), Pacific Poison Oak (Rhus diversiloba) and Swordfern Polystichum munitum (SCS, 1983).

The areas not covered by trees, shrubs, forbs and herbs are covered by a dense mat of grasses. A large percentage of the extant grassland species have been human-introduced (Franklin, 1973). 
FAUNA

Many species of wildife inhabit the watershed. There are 79 bird species, 21 mammal species, four lizard species, and seven amphibian species in the watershed (City of Gresham, 1980). Only the burrowing animals (such as Gophers (Thomomys spp.), Moles (fam. Talpidae), Earthworms (Oligochaeta) and Insects (Insecta) affect the hydrologic response of the watershed, although the watershed response does affect many riverine and riparian species. Anadromous fish include steelhead (Salmogiardneri) and Coho Salmon (Oncorhynchus kisutch). Resident fish include Cutthroat Trout (Salmoclarki), Redside Shiner (Richardsonius baltheatus) and Lampreys (Lampetra spp.) (City of Gresham, 1980). The recommended low flow for fish life from June $16 \mathrm{th}$ to October $16 \mathrm{th}$ is four cfs (Oregon state division of Fish and wildife, personal communication). The highest low flow ever recorded for the years or record was $1.8 \mathrm{cfs}$ in 1954 .

DISCHARGE

For the period of record at the sycamore gaging station, the maximum recorded flow was 2620 cfs (December 
22nd, 1964), and the lowest recorded flow was 0.10 cfs (August 7 th to 11 th, 1973). Fig. 18 depicts the average annual hydrograph at the gaging station. The annual runoff distribution shows high values in the winter months and low values during the summer months. Fig. 19 shows the maximum flows of record, and Fig. $2 \emptyset$ shows the minimum flows of record. Fig. 21 depicts the average return periods of various magnitudes of discharge for the total period of record.

WATERSHED HYDROLOGY

The natural hydrologic regime within the Johnson Creek basin was a result of interactions between all of the aforementioned physical parameters. During the summer months the vegetation is flush and the transpiration rates are high. High temperatures, solar radiation input, and large amounts of leaf area result in a high amount of evaporation and a low percentage of direct runoff. In contrast, the high winter rainfall is subject to few initial abstractions. The vegetation is mainly dormant and transpiration is minimal. Evaporation is slow due to low ambient temperatures, high relative humidity and low amounts of solar radiation. Due to the shallow impermeable clay 


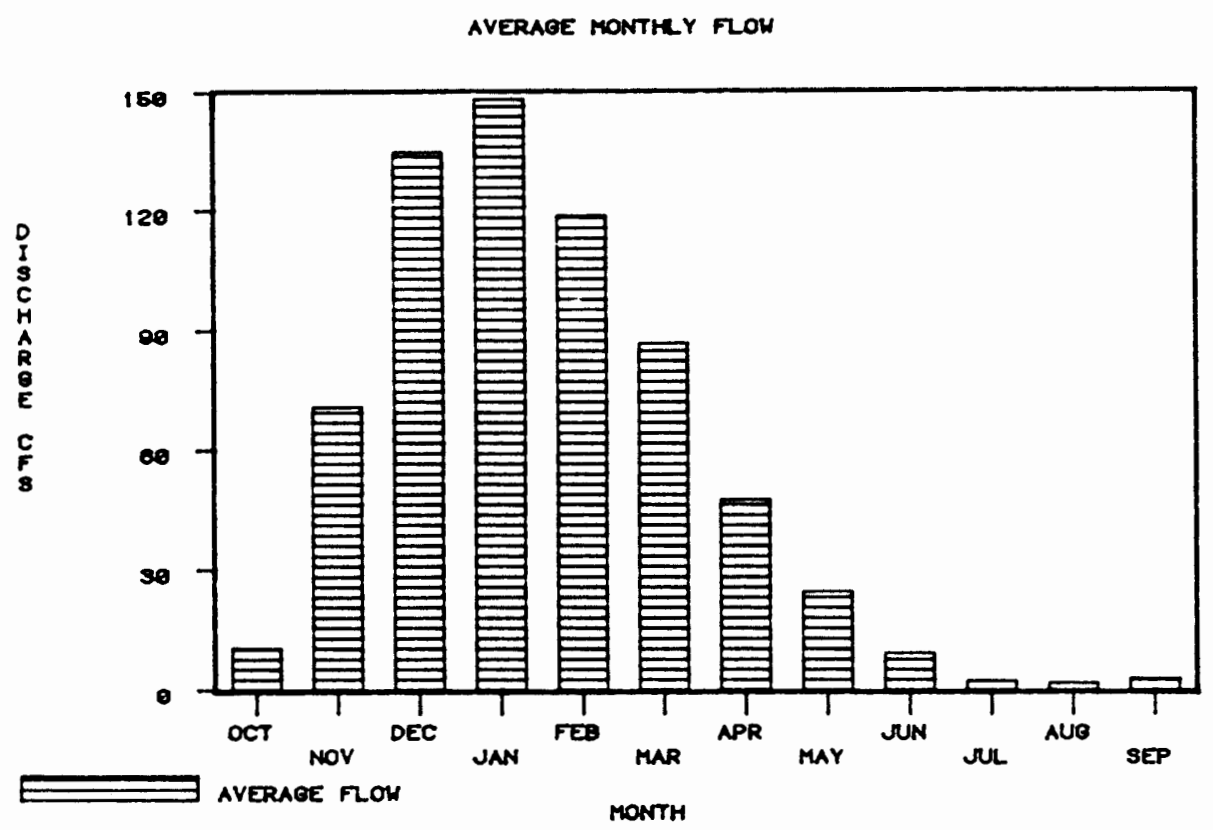

Figure 18. Johnson Creek Average Monthly Flow. (USGS Data) 


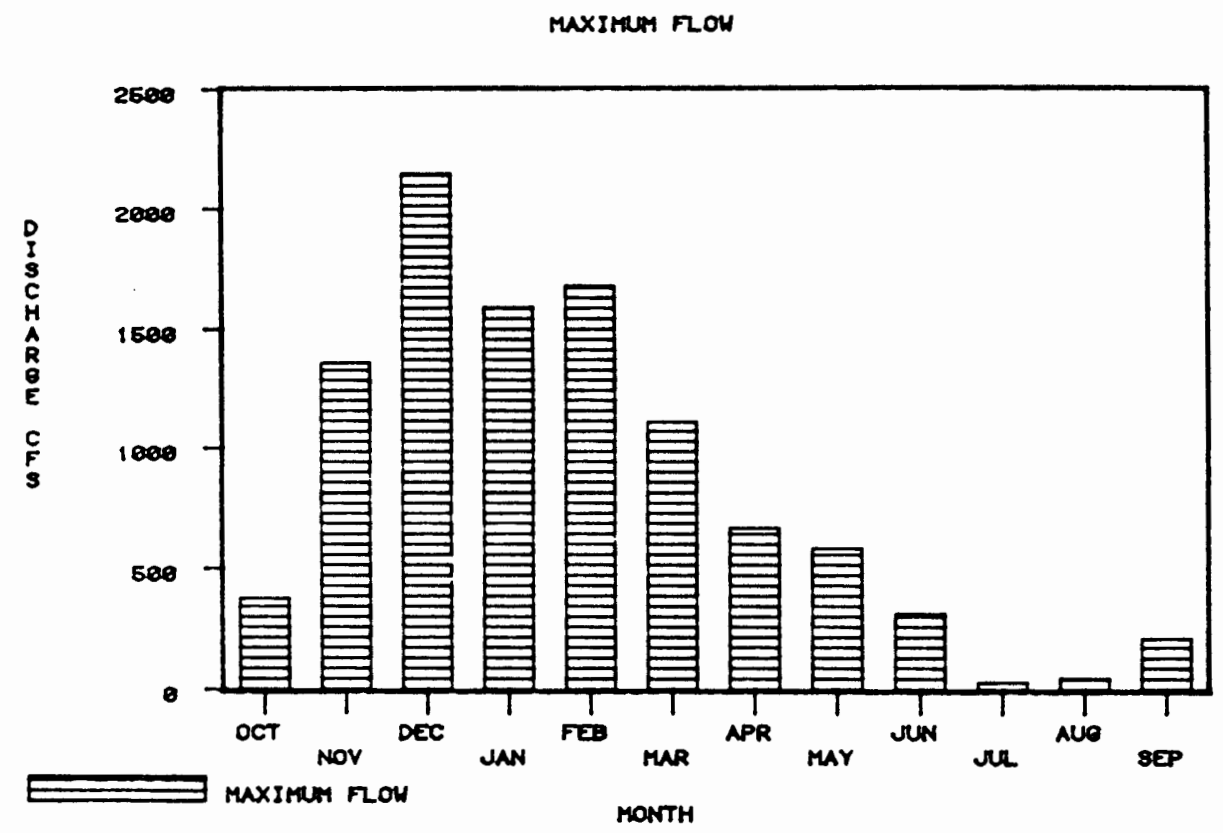

Figure 19. Johnson Creek Monthly Maximum Flow (USGS Data) 


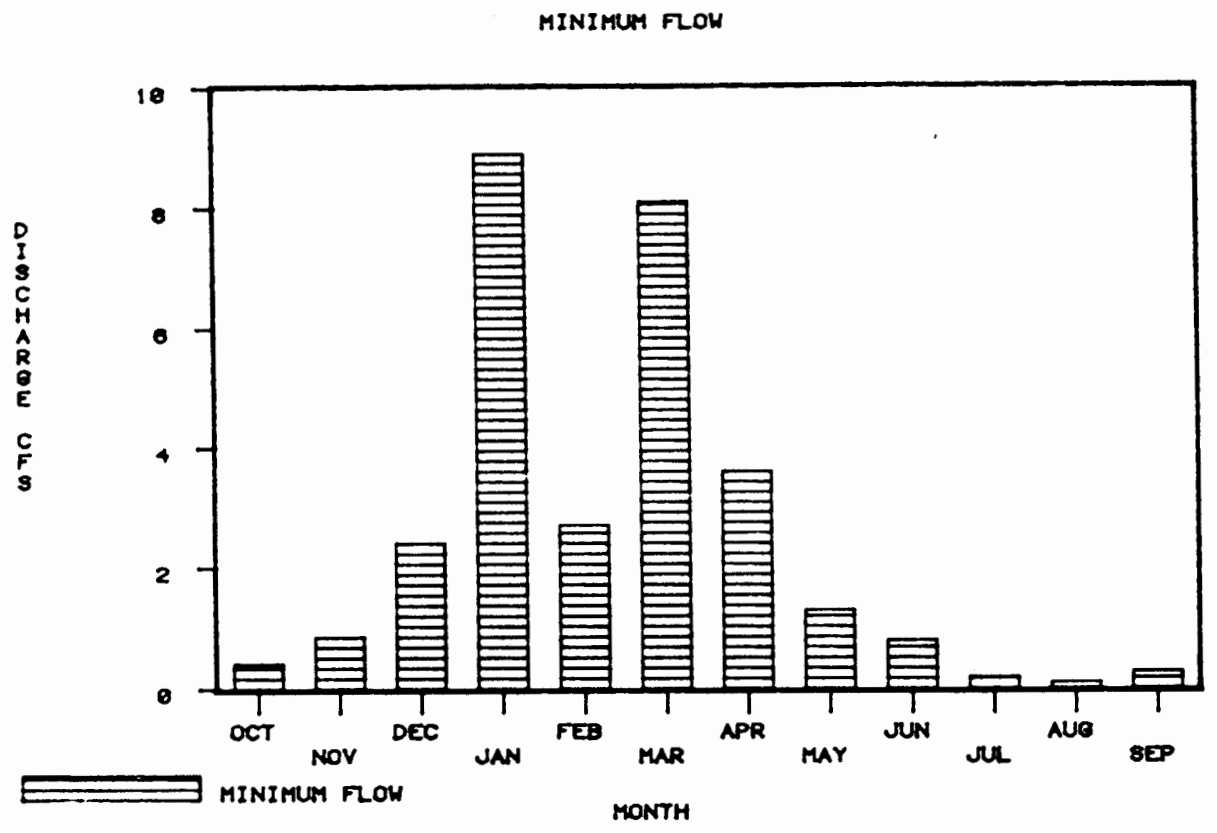

Figure 20. Johnson Creek Monthly Minimum Flow. (USGS Data) 


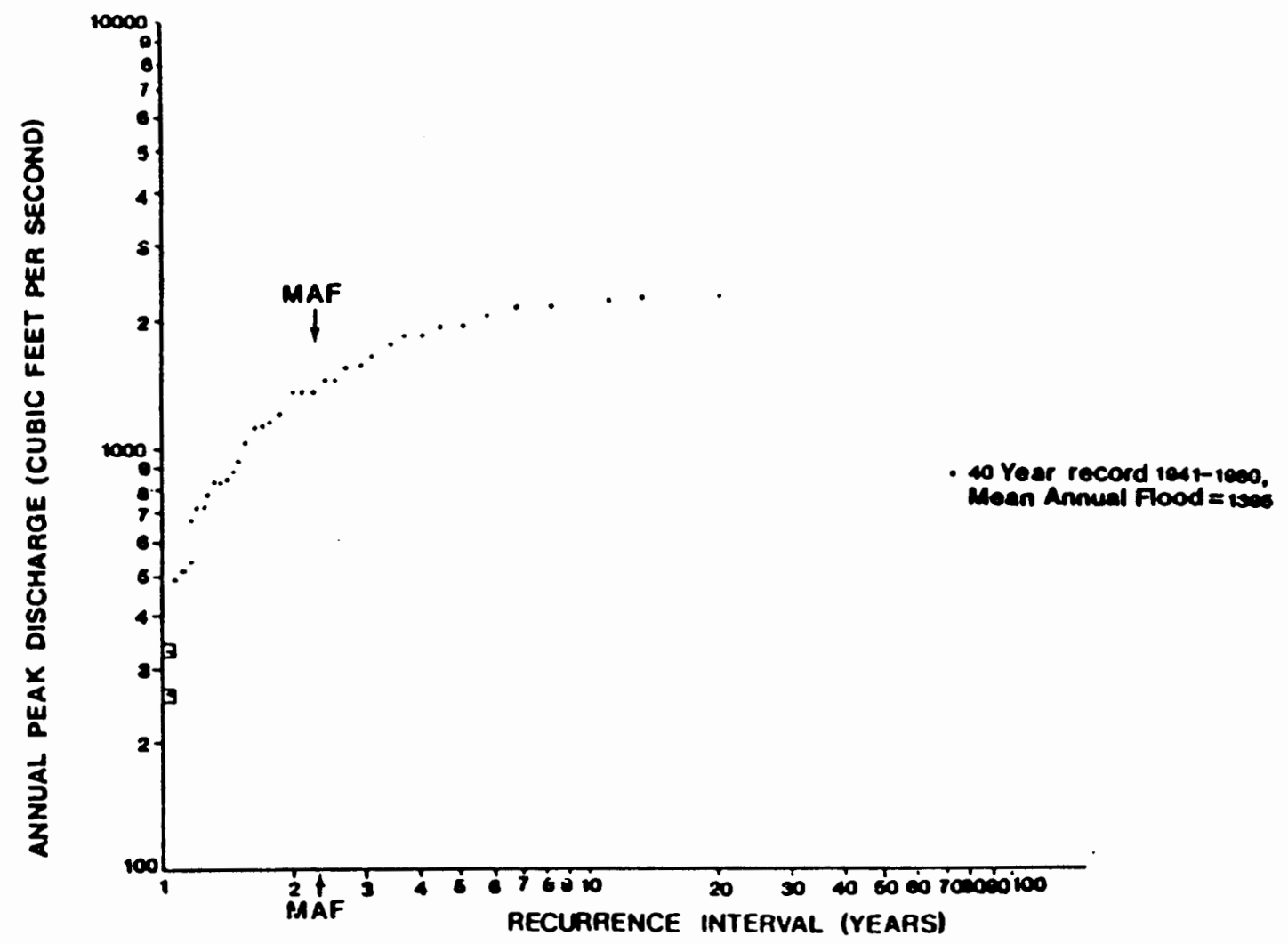

Figure 21. Johnson Creek Flood Frequency Curve (Seltzer, 1983, p. 105) 
layer underlying most of the basin, the percentage of direct runoff is high. The winter-summer precipitation-runoff regime is depicted in Figures 6 and 18 respectively.

The average annual percentage of rainfall that results in direct runoff is 54.5 percent (standard deviation of 10.8) with a maximum of 78 percent and a minimum of 25 percent. Lag times between center of mass of precipitation and center of mass of runoff average approximately 25 hours (Laenen, 1980) (Table I).

In addition it was of relevance to the hydrologic analysis in this thesis to see how well the total flow correlated with total annual precipitation, and how well minimum flows correlated with summer precipitation (May through September). Using annual precipitation and streamflow data from 1941 to 1982 spearman's rank correlation coeffecient was used to test for these correlations. The results were that total annual runoff correlated with total annual precipitation with a spearman's $r$ of $\emptyset .80$ (at a one tailed significance level of less than $\emptyset . \emptyset \emptyset 1)$, but there was no significant correlation between annual minimum flow and annual summer precipitation. 
HUMAN USE

There has been occasional human use in the area of Johnson Creek since at least 13,000 years ago. Until pioneers got a strong foothold in the 19 th century the native inhabitants often burned the forests and brushlands to provide areas for hunting. The first settlers of European descent are reported to have been the william Johnson family, who arrived in 1846, and for whom the creek is now named (Johnson Creek itself was originally named Panther Gulch). Later settlers cleared woodlands on flat areas for small farms. As the City of Portland grew, the increasing demand for timber resulted in the logging of most of the remaining nearby woodlands. Farming and grazing activities became easier with the increase in cleared area. Present non-urban land uses include woodlots, pasture, fruit orchards, and the farming of berries, grains and vegetables. The City of Gresham (Fig. 1) (incorporated in 1905) is located almost wholly within the Johnson Creek watershed. It was first settled in 1850 and started out as a small node of commerce for local farmers. With the advent of more advanced transportation systems (macadam highways, the old light rail lines, then modern freeways) Gresham became a bedroom community for the city of Portland. It has increased in population at an increasing rate throughout its 
history (Fig. 22, Table IV). The city grew by 559 percent from 1960 to 1977, and has been the fastest growing city in Oregon since 1970 (City of Gresham, 1980). (It should be noted that the incorporated areas of the city as well as the census tract areas have increased, and as a result the population figures should not be taken as indicators of an increase in population density): Seltzer (1983) analysed building permit activity in the Johnson Creek basin area and showed the areas that had undergone the greatest growth rate (Fig. 23). Current trends predict a population of $8 \emptyset, \emptyset \emptyset \emptyset$ by the year 2030, and the Gresham Community Development Plan zoning map shows all but a few small areas zoned for development. Development plans for the near future include the introduction of a new mass transit system (the Metropolitan Light Rail system), a high density residential development in the city center expected to accomodate $8 \emptyset \emptyset \emptyset$ people, and a 1 million square foot shopping center in the city core area (Brown and Caldwell, 1980). Sprawling single family subdivisions are increasingly covering the non-incorporated portions of the watershed (Figs.23 and 24): 


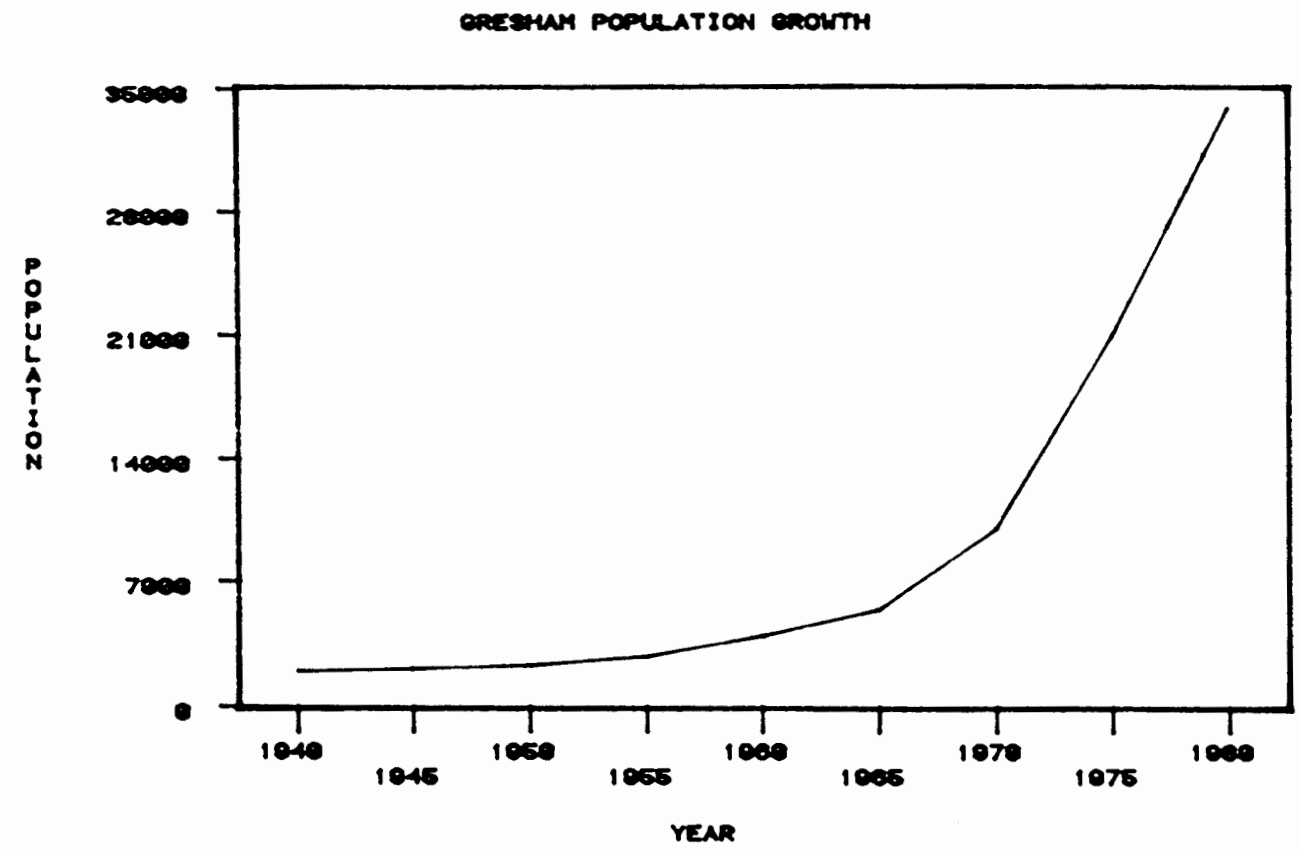

Figure 22. City of Gresham Population Growth. (Census Bureau Data) 

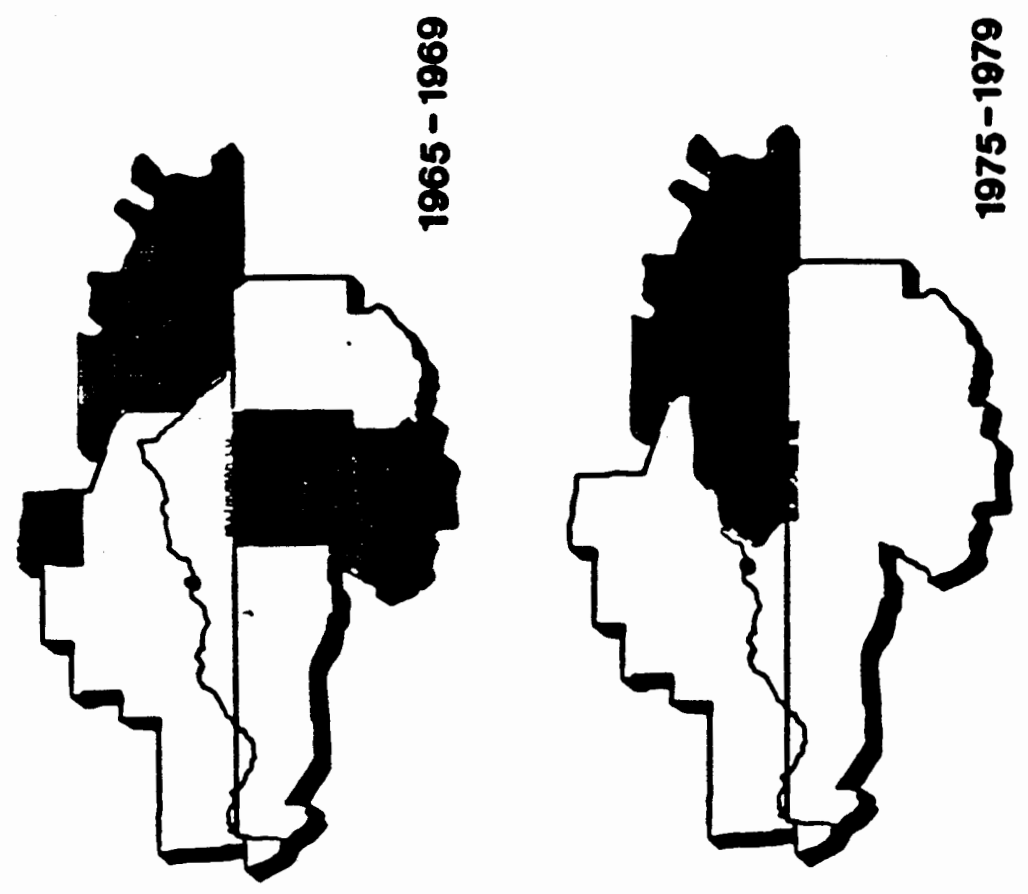

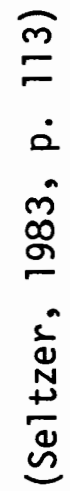

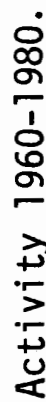
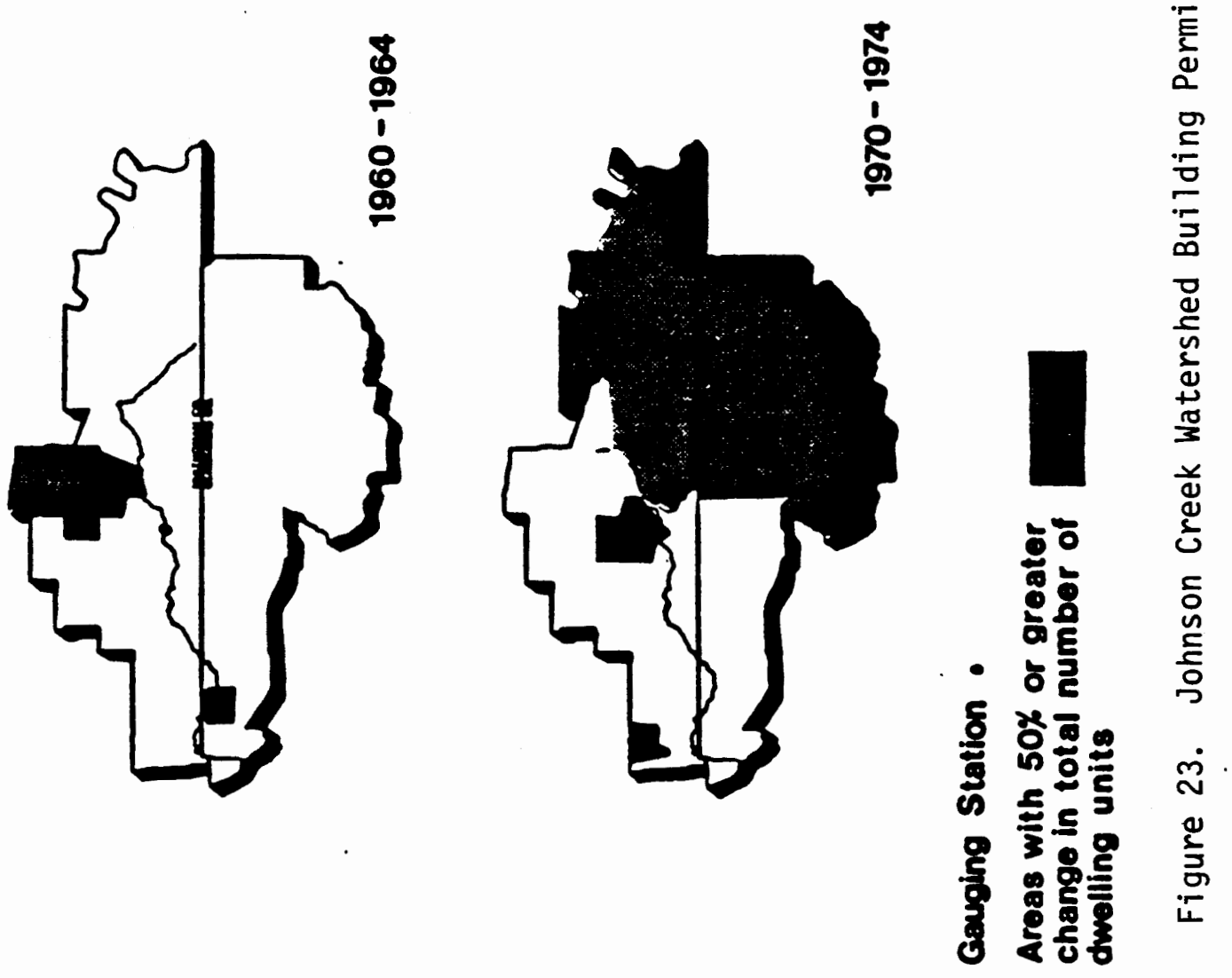


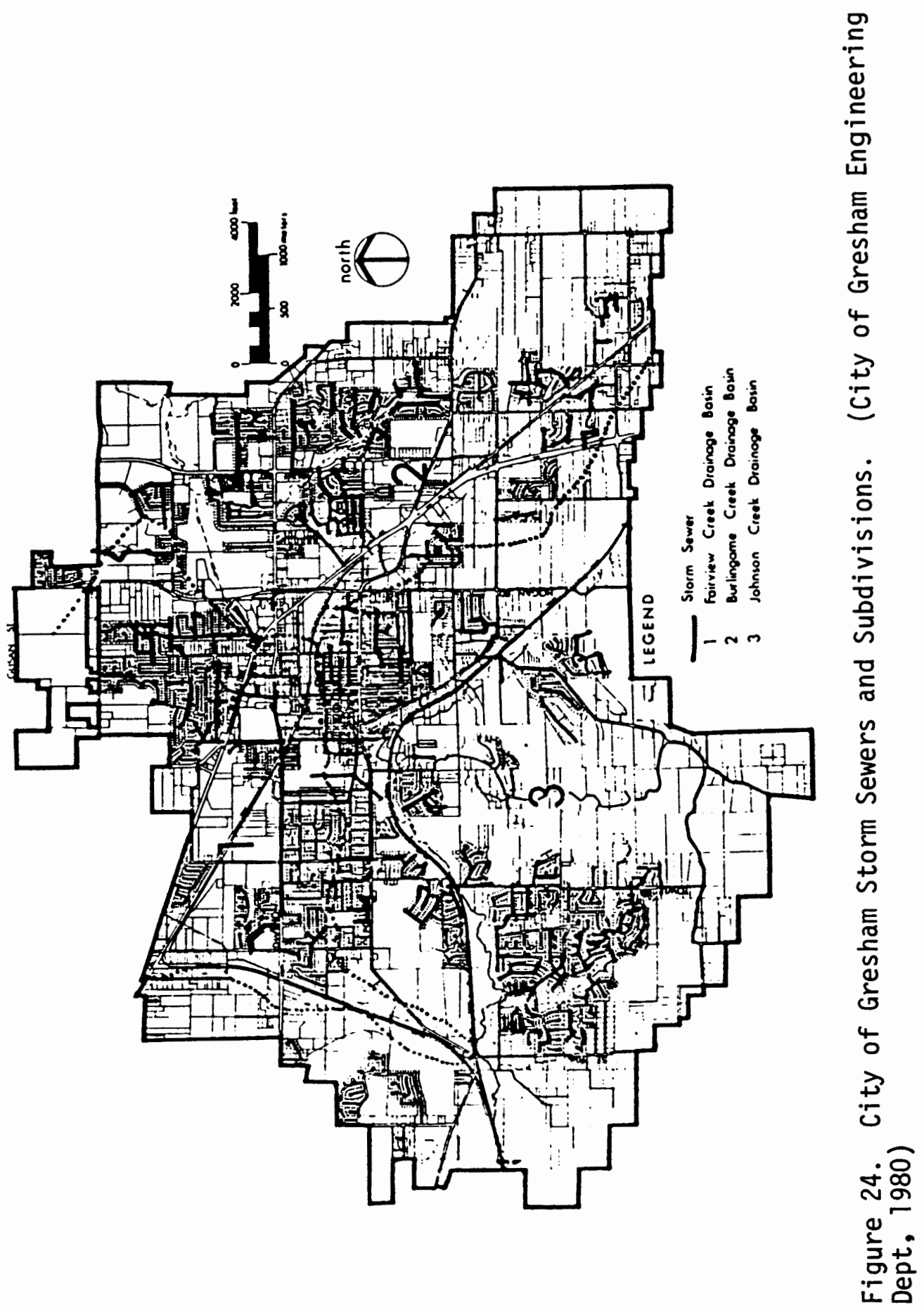


TABLE IV

GRESHAM POPULATION GROWTH

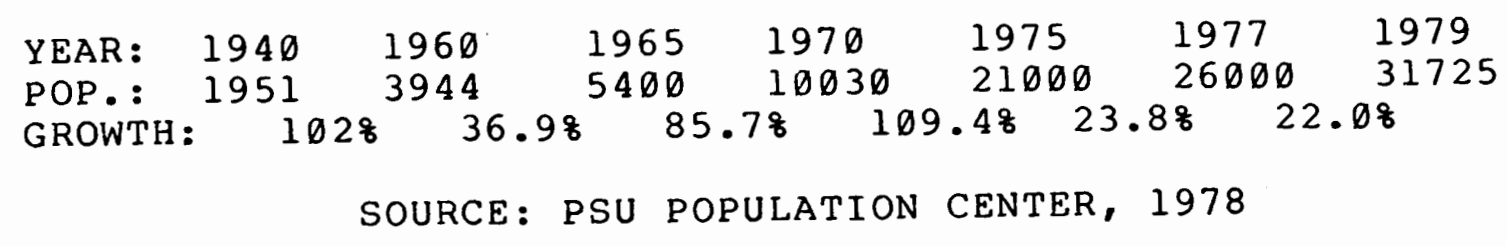

FLOOD CONTROL EFFORTS

Johnson Creek has always overflowed its banks. This was never a problem until white settlers started building structures on the floodplains. In the early 1930's the Works Progress Administration (WPA) cleared, enlarged, straightened and riprapped about 67 percent of the lower six miles of the creek. In 1965 Multnomah County spent 17,000 clearing brush and silt from much of the lower channel. More than $\$ 200,000$ has been spent by various Federal and local agencies (The corps of Engineers ( $C$ of $E$ ), the soil Conservation Service (SCS), the Southeast Johnson Creek Flood Control District (now defunct), the Columbia Regional Association of Governments (CRAG), the Metropolitan Service District (METRO), and Multnomah County) on advance engineering plans, economic feasibility studies, and preliminary proposals. other efforts to mitigate the 
flooding problems were hampered by the lack of an effective regulatory agency with jurisdiction over the whole watershed. Formation of such an agency and funding for actual construction has been defeated many times by voters who could not accept the suggestion that their upstream property improvements were responsible for increased flooding in the lower basin. It is the activity of citizens groups that has defeated such funding measures. The City of Gresham planning department is aware of the urbanization vs. flooding problem and has a policy to only let urban development with a minimum impact occur near "natural areas" and other hydrologic sumps (e.g.: no clearcutting is allowed on slopes in excess of 35 percent). No significant flood control work has been done in the basin since 1965. 
CHAPTER IV

HYDROLOGIC ANALYSIS

DATA

Three methods to detect and document a change in the rainfall-runoff relationship are in general use:

upstream-downstream,

(2) paired watershed, and before-after. The upstream-downstream method requires two gaging stations along the river. There is only one on Johnson Creek. The paired watershed method requires a "control" watershed for comparison, one that has not undergone urbanization and that has the same climatic and physical features as the study watershed. For this study no such watershed was available with comparable streamflow records. The before-after method compares data from before the period of watershed change with data from the period during or after the change. This method was chosen for the study as the available data fit the requirements.

To determine whether a change in the hydrologic regime in the Johnson Creek watershed had occured during the study 
period, precipitation and runoff data were collected for the period 1941 through 1982, and subjected to analysis by several statistical and graphical techniques.

The data analysis was separated into two components: (1) annual data series were subjected to a number of statistical tests and graphical analyses; and (2) average unit hydrographs were produced from several representative storms from the early 1940's, then compared with two similar average unit hydrographs developed from storms during the early 1960's and 1980's.

Annual data series selected for analysis were:

1. Johnson (USGS\#14211500)

Creek-Sycamore

Gaging

station

a. Total Annual Flow (cfs)
b. Minimum Annual Flow (cfs)
c. Annual Peakflow (cfs)

2. National Weather Service Climatological station \#6749 (Portland City)

a. Total Annual Precipitation (inches)

b. Summer Precipitation (inches) (l May through 30 Sept.)

All of the data were checked to ensure homogeneity. The station history for the USGS Sycamore gage was checked throughout the period of record to ensure that any physical changes at the gaging site would not affect the streamflow readings. No changes were found that were not compensated for by a concomitant change in the streamflow rating table. In addition, no channel changes were made above the gaging station that would affect the runoff hydrograph (Laenen 
1983, personal communication). The Portland (city) precipitation gage was moved from the Customs House to the KGW-TV station in June of 1973, a distance of approximately פ.5 mile to the south-west with an elevation gain of 129 feet. Any difference in precipitation between these two sites is undetectable on the best available isohyetal maps of annual precipitation (Figure 7) (Wantz, et al, 1983) and the series is considered to be homogenous.

These data series were chosen for several reasons. Both precipitation data sets were included to ensure that any change in runoff patterns was not caused by a change in precipitation. The Johnson Creek runoff data was included to test if urbanization had lowered the minimum flows and/or increased peakflows, the most commonly documented effects of urbanization on a runoff hydrograph.

These data series are expressed as time series in Figures 25 to 29. In addition, for the first set of statistical tests the data series were separated into two time periods for comparison: 1941 through 1961 (before) and 1962 through 1982 (after).

STATISTICAL ANALYSIS (BEFORE-AFTER)

The data series were first analysed to ensure that 


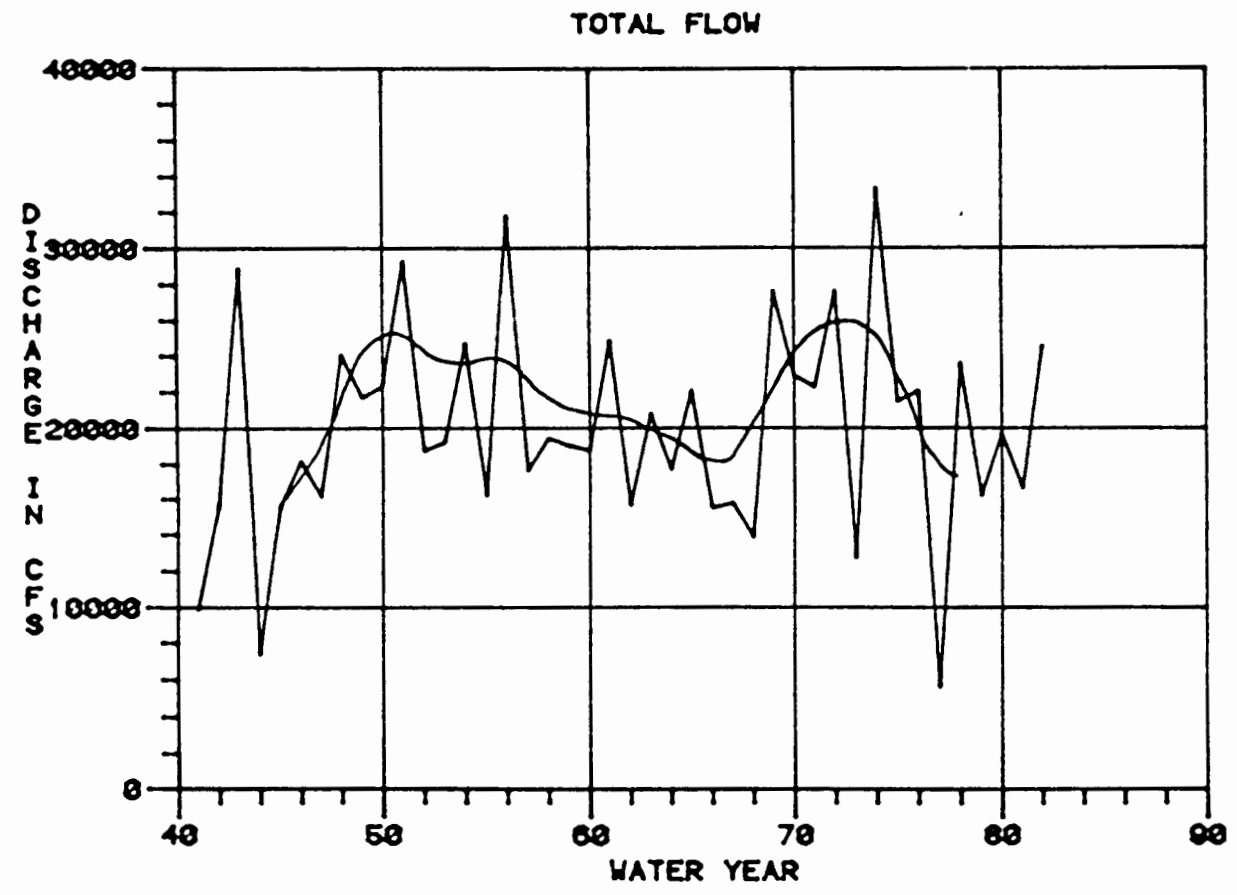

Figure 25. Johnson Creek Annual Total Flow (Smoothed with a 9-term Weighted Mean) (USGS Data) 


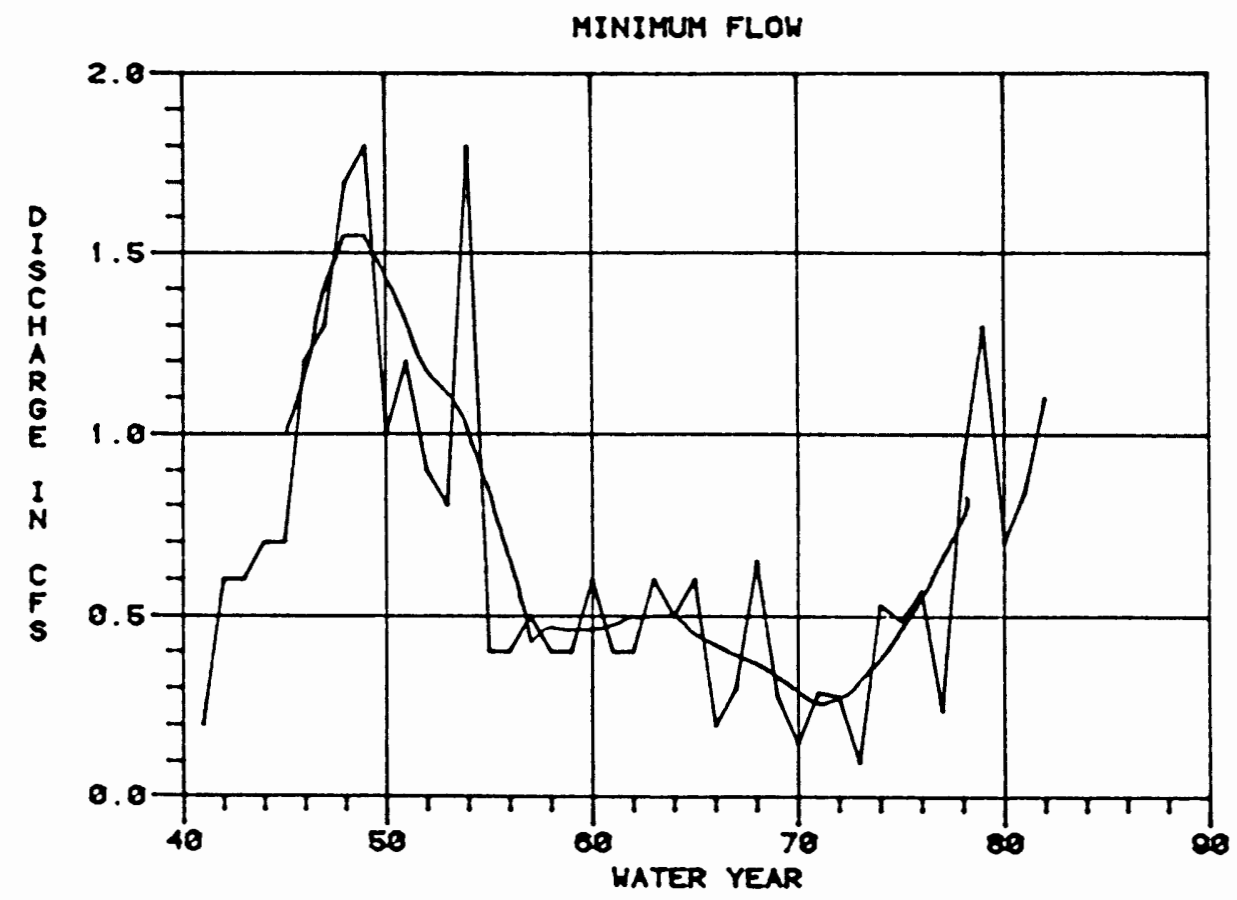

Figure 26. Johnson Creek Annual Minimum Flow (Smoothed with a 9-Term Weighted Mean) (USGS Data) 


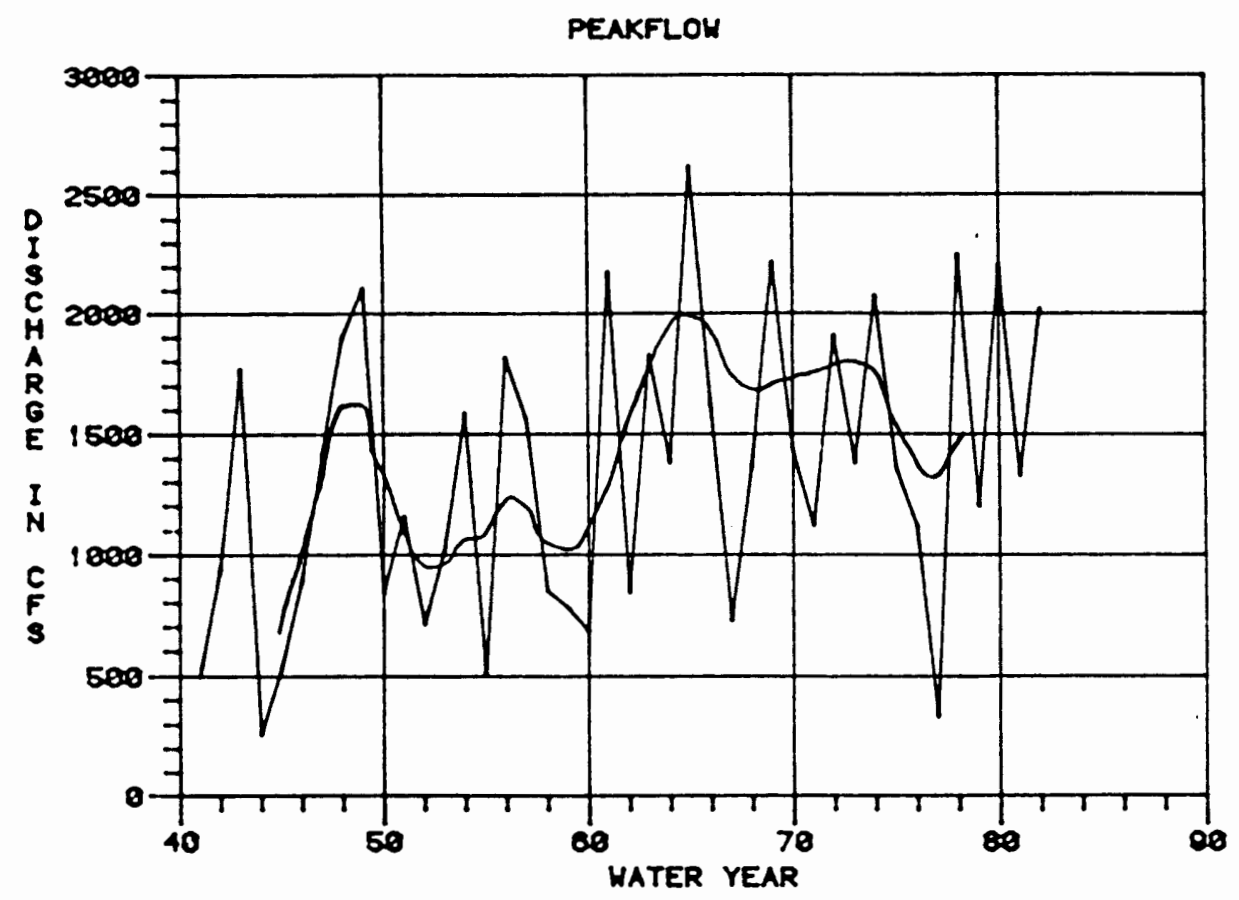

Figure 27. Johnson Creek Annual Peak Flow (Smoothed With a 9-Term Weighted Mean) (USGS Data) 


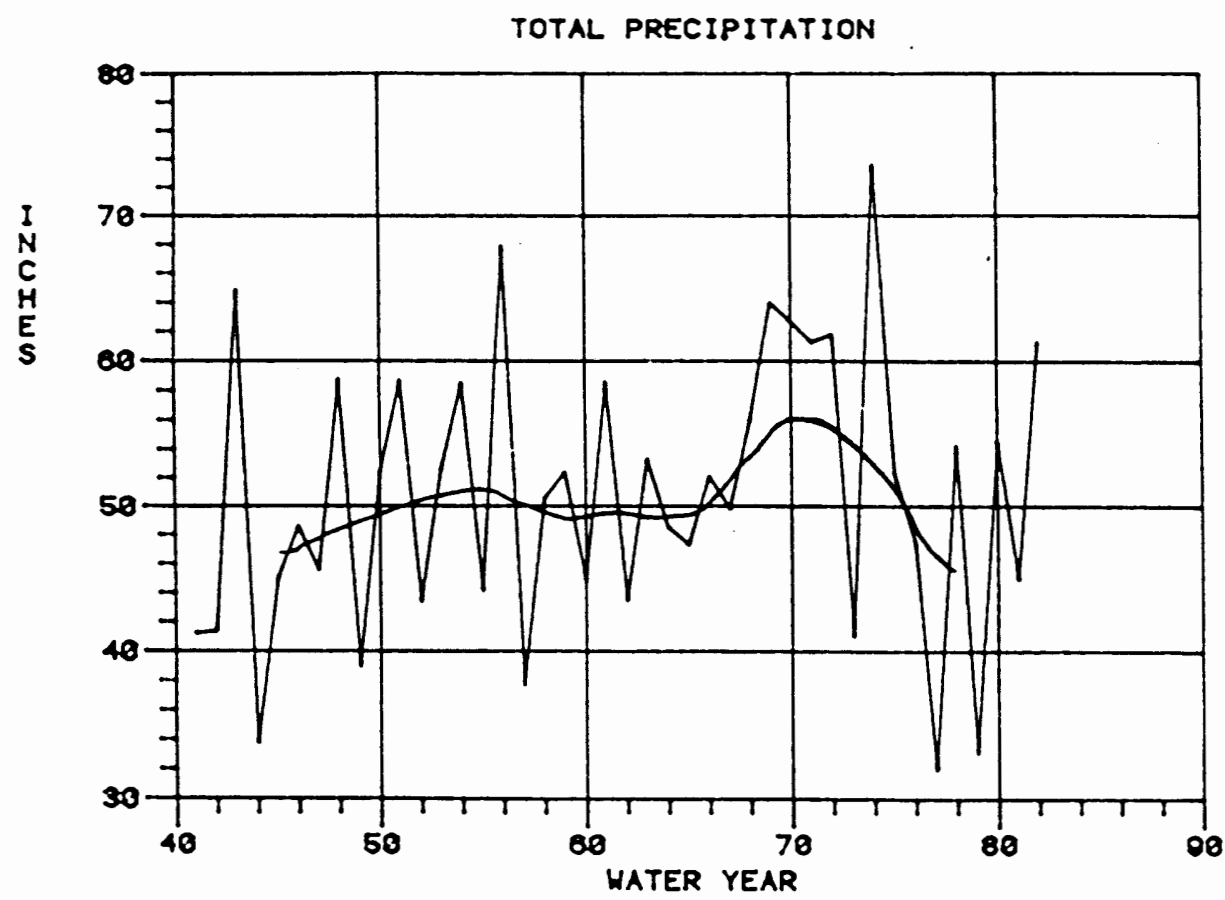

Figure 28. Johnson Creek Watershed Annual Total Precipitation (Smoothed With a 9-Term Weighted Mean) (NOAA Data) 


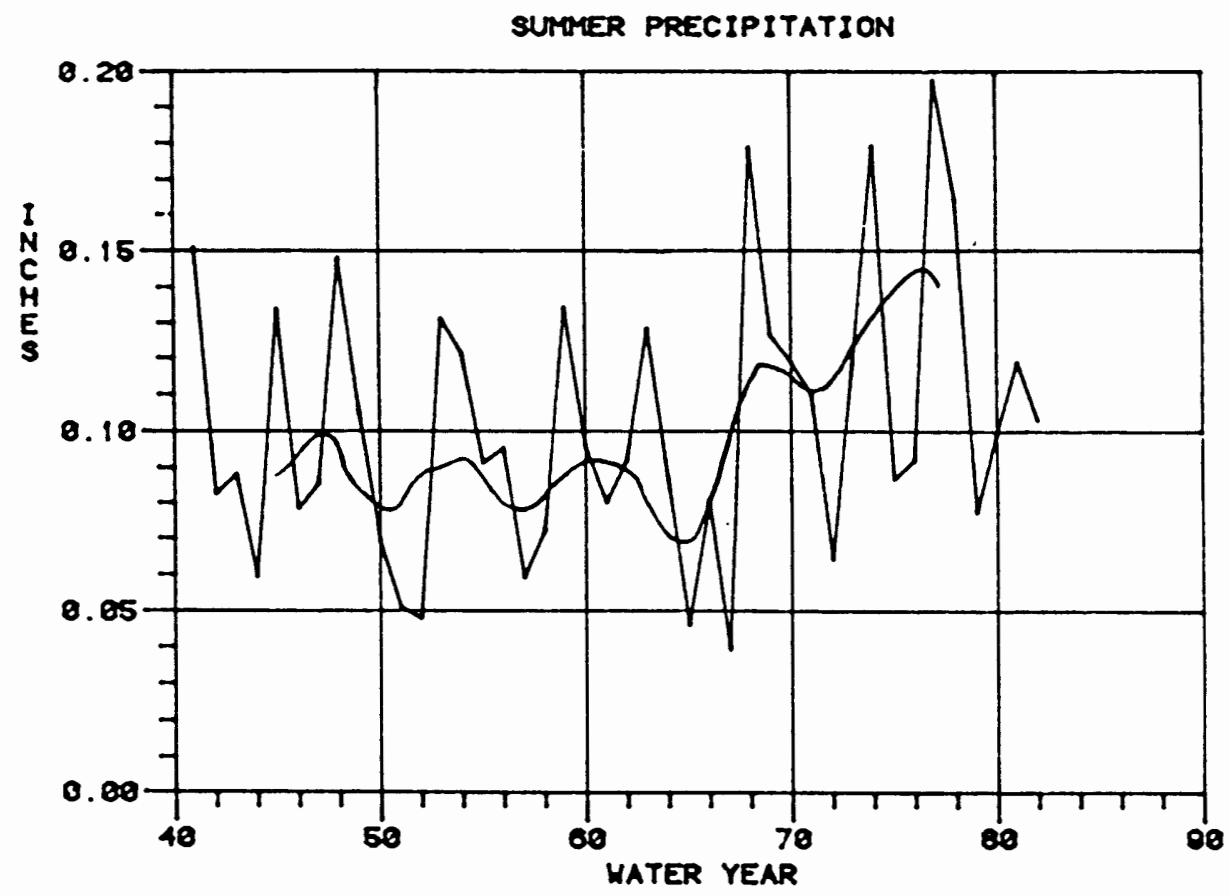

Figure 29. Johnson Creek Watershed Annual Summer Precipitation (Smoothed With a 9-Term Weighted Mean) (NOAA Data) 
they fit the assumptions required for commonly used parametric statistical tests. The main assumptions are that (1) the data fit a normal distribution, (2) the variances between the two data sets (1941 to 1961 vs. 1962 to 1982 for each variable) are equal, and (3) the samples are independent (McCuen and James, 1972). If the data do not fit these assumptions, the use of parametric tests can lead to erroneous conclusions. The degree to which the results of the parametric tests are affected by violations of assumptions depends on the degree to which the assumptions have been violated. Hence, if the data approximate the assumptions but do not fit them exactly, the parametric tests may still be useful. However, The researcher must be very careful in interpreting these results if they are close to the chosen significance level $(+/-\emptyset .05$ for this study) as the probability of making a type one error is increased; that is, the probability of rejecting a true hypothesis (Haan, 1977).

First, the data series were tested to determine whether or not they fit a Normal distribution. The non-parametric Kolmogirov-Smirnov one sample test (Siegel, 1956) was used for this purpose. Results indicate that only total precipitation and peakflow fit the Normal distribution (using the mean and standard deviation as estimators).

Second, the data series were tested for equality of 
variances using the F-test inherent in the SPSS T-TEST procedure. All five variables were split up into the two data sets (1941 to 1961 vs. 1962 to 1982) and their respective variances were compared. Variances between the two time periods were found to be equal for each of the variables.

The third assumption necessary for the use of parametric tests is that the data series consists of independent observations. This condition is especially important in the evaluation of hydrologic data, as it is often the case that an observation in one time period is correlated with the observation in the preceeding time period. If there is reason to suspect that a data series is not independent, it may be tested using the Runs test for randomness (Ponce,1980). If the data are random it may be held that they are independent as well. The results of the Runs test indicate that the minimum flow and total precipitation data sets are not random.

The results of the tests for violation of assumptions (Table V) indicate that none of the data meet all the criteria for parametric tests. Therefore, non-parametric tests were used for this analysis.

Non-parametric statistical tests are tests that do not depend on the usual assumptions, but in some cases may be weaker as they do not use as much information from the data. 


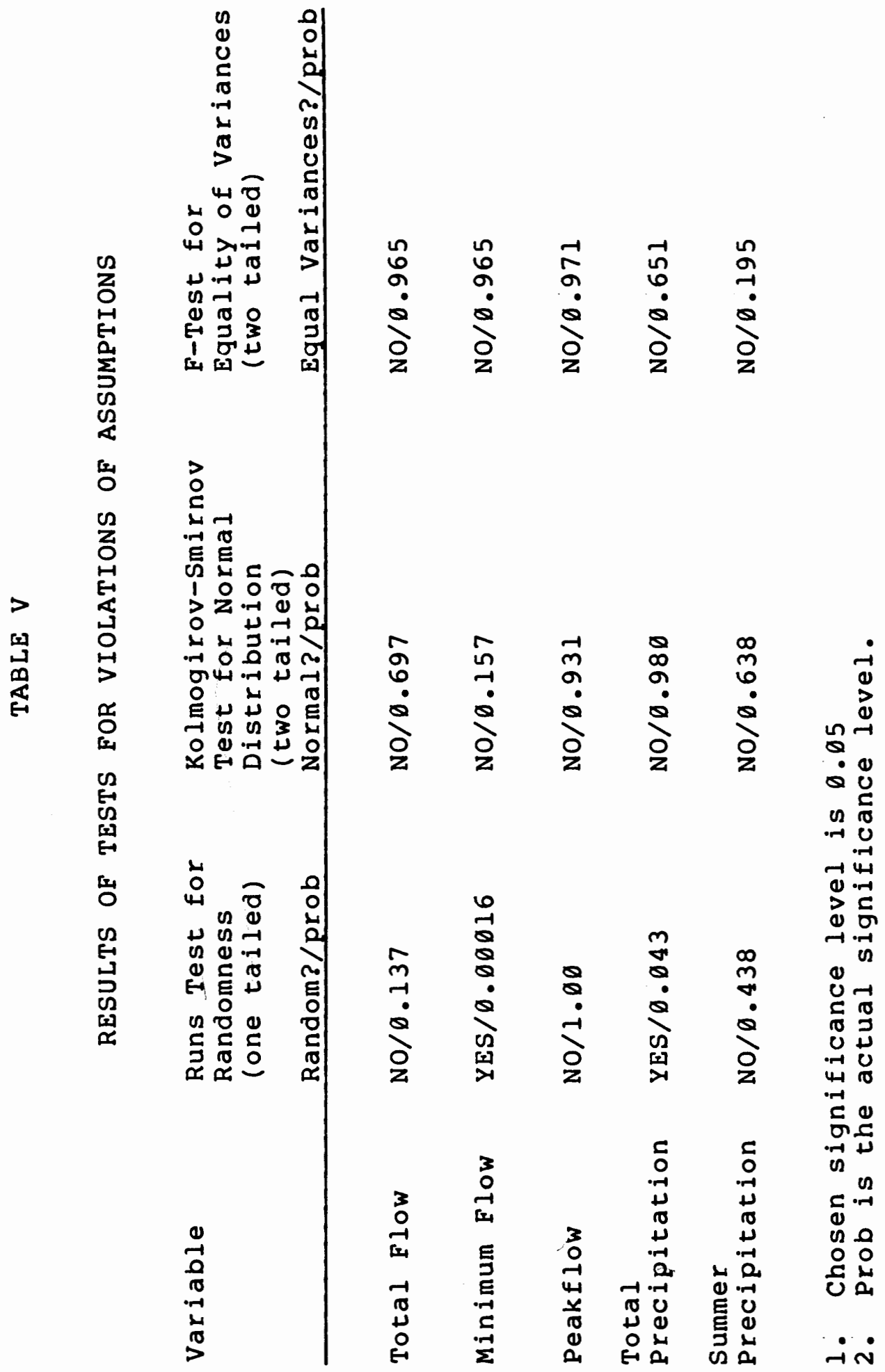


It has been suggested that as hydrologic data almost never fit a normal distribution, and that as urbanization may alter the distribution of the data over time, non-parametric tests are preferable to parametric tests for the analysis of hydrologic change (Lazaro, 1979, Mcuen and James, 1972). In addition, hydrologic data series are usually skewed with the extreme values towards the right. Many non-parametric methods use the median as an indicator of central tendency, and hence are more applicable to hydrologic data than parametric tests.

Several non-parametric tests were used to compare the data from 1941-1961 with the data from 1962-1982. The Mann-Whitney U-test was used to test if two independent sample groups come from the same population. It is one of the most powerful of the non-parametric tests, having approximately 95 percent the efficiency of the non-parametric T-test (Siegel,1956). The Median test, which tests if one data set has a higher median than another data set, is not as powerful as the Mann-Whitney U-test, but was used as a check. The Kolmogorov-Smirnov two sample test was used to determine whether or not two independent data sets have been taken from populations having the same distribution. It uses differences in central tendency, skewness, and kurtosis as the determining factors. These factors are assessed by comparing the cumulative frequency 
distributions of the two data sets. As a check on the non-parametric tests a parametric t-test was also run on the data sets.

The results of the Mann-Whitney U-test (Table VI) indicate that minimum flows have significantly decreased and that peakflows have significantly increased during the period under study. The test does not show a significant change in total flow, total precipitation, or summer precipitation. The lack of a significant change in precipitation eliminates the most probable alternate reasons for a hydrologic change other than urbanization. This makes the significant changes in peakflows and minimum flows more meaningful. While the results of the Median test are not as significant as the results from the other tests, they also indicate a decrease in minimum flows and an increase in peakflows. The results of the Kolmogirov-smirnov test also concur with the findings of the Mann-Whitney $U$ test, and the results of the t-test are in agreement with the results of these three non-parametric comparativè tests.

The wilcoxon matched-pairs signed-ranks test was used by Lazaro (1979), and Mcuen and James (1972) to test for a change in peakflows. They both ran the test on a watershed that had undergone urbanization, and their results showed a highly significant (probability level less than 0.01 ) increase in the annual peakflow series. They noted that 


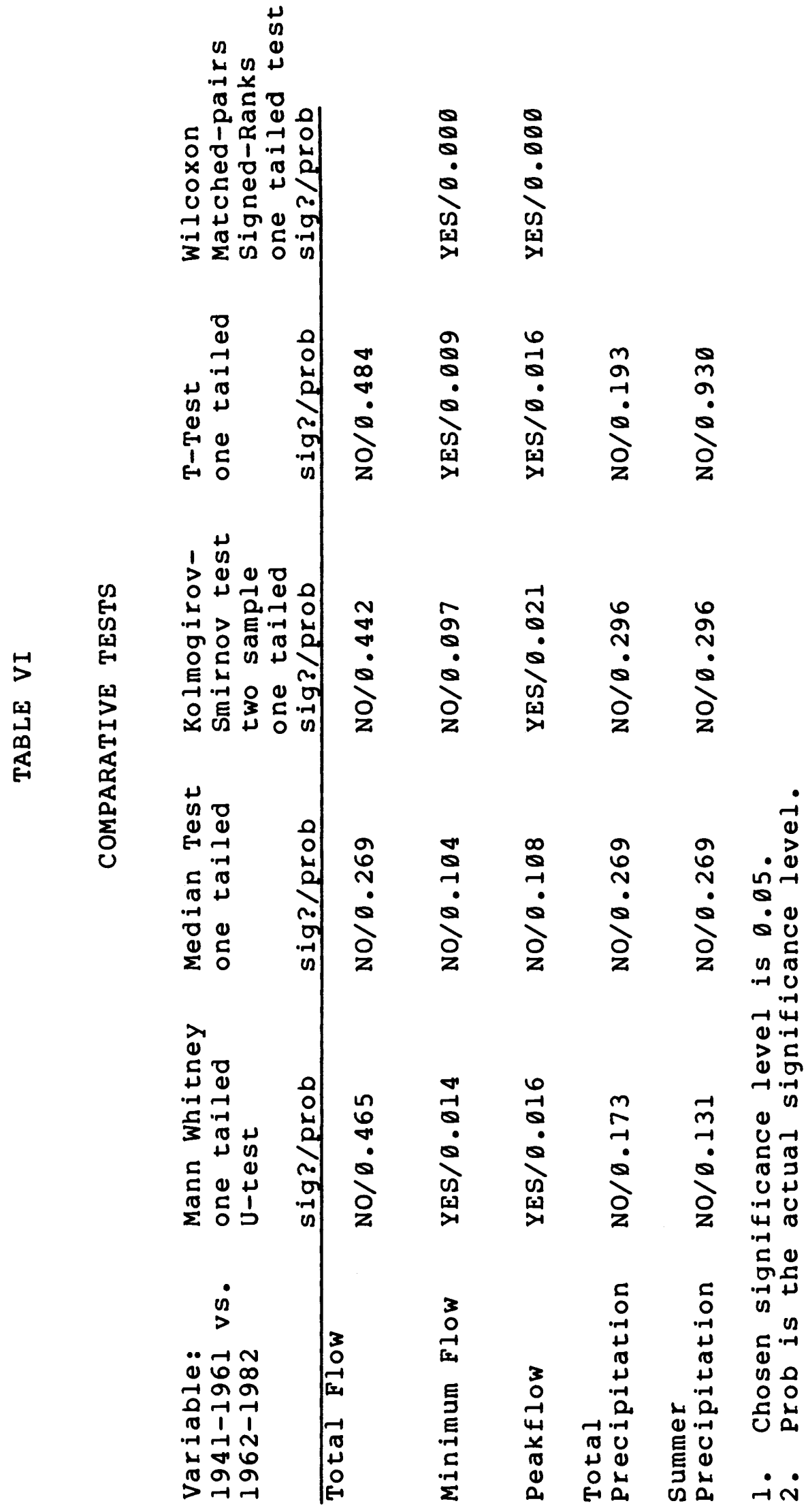


time series data can be treated as two related samples by separating the time series into two periods, ranking the data from the each period, taking the difference between the two ranks, and testing for a significant number of plus or minus scores. This method was used to test peakflows and minimum flows on Johnson Creek. The results indicate a highly significant increase in peakflows and a highly significant decrease in minimum flows. The significance levels associated with the results from this test are much higher than the results from the other tests.

In Table VII are tabulated the mean, median, and coefficient of variation for each variable for the before and after time periods. The percentage of change between the two time periods is also presented. The coefficient of variation is a dimensionless statistic defined as the standard deviation divided by the mean, and essentially normalizes the standard deviation. This gives the user an indication of how valid the mean value is as a descriptor of the data distribution. The higher the coeffecient of variation, the more variable the data series. The mean, standard deviation and coeffecient of variation are included as the median does not have a comparable indicator of data variability. The interannual variability of the minimum flow and peakflow data series is relatively high. The percentage of change between the before and after data sets is high for minimum flow and 
TABLE VII

COMPARISONS OF MEANS AND MEDIANS

\begin{tabular}{|c|c|c|c|c|c|c|}
\hline & & $1941-60$ & C.V. (1) & $1961-80$ & C.V. & $\begin{array}{l}\text { Percent } \\
\text { of Change }\end{array}$ \\
\hline $\begin{array}{l}\text { Total } \\
\text { Runoff } \\
\text { (cfs) }\end{array}$ & $\begin{array}{l}\text { Mean } \\
\text { Median }\end{array}$ & $\begin{array}{l}19990 \\
19043\end{array}$ & 0.30 & $\begin{array}{l}19915 \\
20804\end{array}$ & 0.30 & $\begin{array}{l}-0.48 \\
+9.08\end{array}$ \\
\hline $\begin{array}{l}\text { Minimum } \\
\text { Elow } \\
\text { (cfs) }\end{array}$ & $\begin{array}{l}\text { Mean } \\
\text { Median }\end{array}$ & $\begin{array}{l}0.838 \\
0.675\end{array}$ & 0.58 & $\begin{array}{l}0.526 \\
0.500\end{array}$ & 0.60 & $\begin{array}{l}-37.28 \\
-26.08\end{array}$ \\
\hline $\begin{array}{l}\text { Peak } \\
\text { Elow } \\
\text { (cfs) }\end{array}$ & $\begin{array}{l}\text { Mean } \\
\text { Median }\end{array}$ & $\begin{array}{l}1143 \\
937\end{array}$ & 0.51 & $\begin{array}{l}1540 \\
1382\end{array}$ & 0.37 & $\begin{array}{l}+34.78 \\
+47.08\end{array}$ \\
\hline $\begin{array}{l}\text { Total } \\
\text { Precip. } \\
\text { (in) }\end{array}$ & $\begin{array}{l}\text { Mean } \\
\text { Median }\end{array}$ & $\begin{array}{l}49.6 \\
48.64\end{array}$ & 0.19 & $\begin{array}{l}52.2 \\
52.29\end{array}$ & 0.20 & $\begin{array}{l}+5.28 \\
+8.08\end{array}$ \\
\hline $\begin{array}{l}\text { Summer } \\
\text { Precip. } \\
\text { (in) }\end{array}$ & $\begin{array}{l}\text { Mean } \\
\text { Median }\end{array}$ & $\begin{array}{l}8.14 \\
7.61\end{array}$ & 0.33 & $\begin{array}{l}9.63 \\
8.89\end{array}$ & 0.37 & $\begin{array}{l}+18.38 \\
+17.08\end{array}$ \\
\hline
\end{tabular}


peakflow, which supports the alternate hypothesis of a change in the rainfall-runoff regime as a result of urbanization. The percentage of change in summer precipitation is apparently high, but this should not be construed as making the drop in minimum flows less valid, as the increase in summer precipitation was not found to be statistically significant (Table VI).

\section{STATISTICAL ANALYSIS (PROGRESSIVE CHANGE)}

Visual examination of the time series in Fgures 25 to 29 is an inadequate method of detecting trends because of the extreme year to year fluctuations in the data. As the high frequency, short period fluctuations are random, unpredictable and essentially "noise", a filtering technique was used to smooth out the data. A nine-term moving weighted average (WMO, 1966) was used to filter out the higher oscillations. This averaging technique puts more weight on the observations that are closer to the principal weight and results in a "low pass" filter, allowing the remaining low frequency fluctuations to remain. These low frequency fluctuations are plotted along with the time series graphs. The filtered time series plots (Figs. 25 to 29 ) and 
the cumulative data plots (Figs. 30 and 31 ) substantiate the conclusions reached in the statistical analysis (before-after). The time series graphs of peakflows (Fig. 27) indicate an increasing trend of the average values. This is also apparent in the plot of cumulative peakflows (Fig. 3ø). The slope of the line is steeper during the later years, indicating increased peakflows. A perusal of Table VI indicates that there has been a significant decrease in minimum flows during the study period. It should be noted that the variability apparent in the time series plot (Fig. 26) and the cumulative plot of minimum flows (Fig. 31) tend to suggest that the variability may be part of a larger fluctuation in the time series that may not be apparent in the short data base that is currently available.

A linear regression analysis (using the equation $\left.Y=A+B^{*} X\right)$ of each of the variables in the annual data series (using time as the independent variable) was performed to determine whether or not a statistically significant trend exists. The results (Table VIII) indicate that only the regression of peakflows possessed a statistically significant slope (at the $\emptyset . \emptyset 5$ significance level), although the slope of minimum flows would have been significant had the $\emptyset .1 \emptyset$ level been chosen as the criteria for significance. The sign of the linear regression line shows a rise over time for peakflows and a decrease over time for minimum 


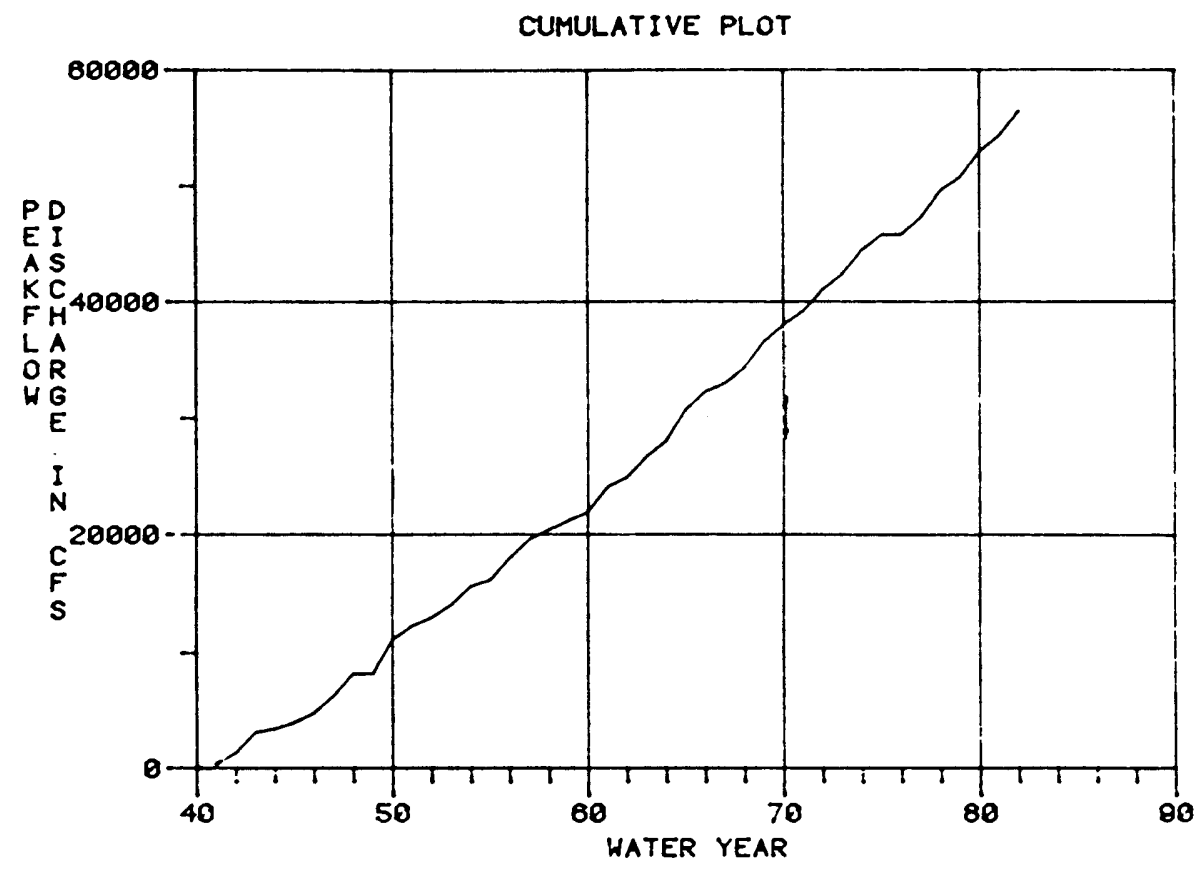

Figure 30. Johnson Creek Peakflow Cumulative Plot. (USGS Data) 


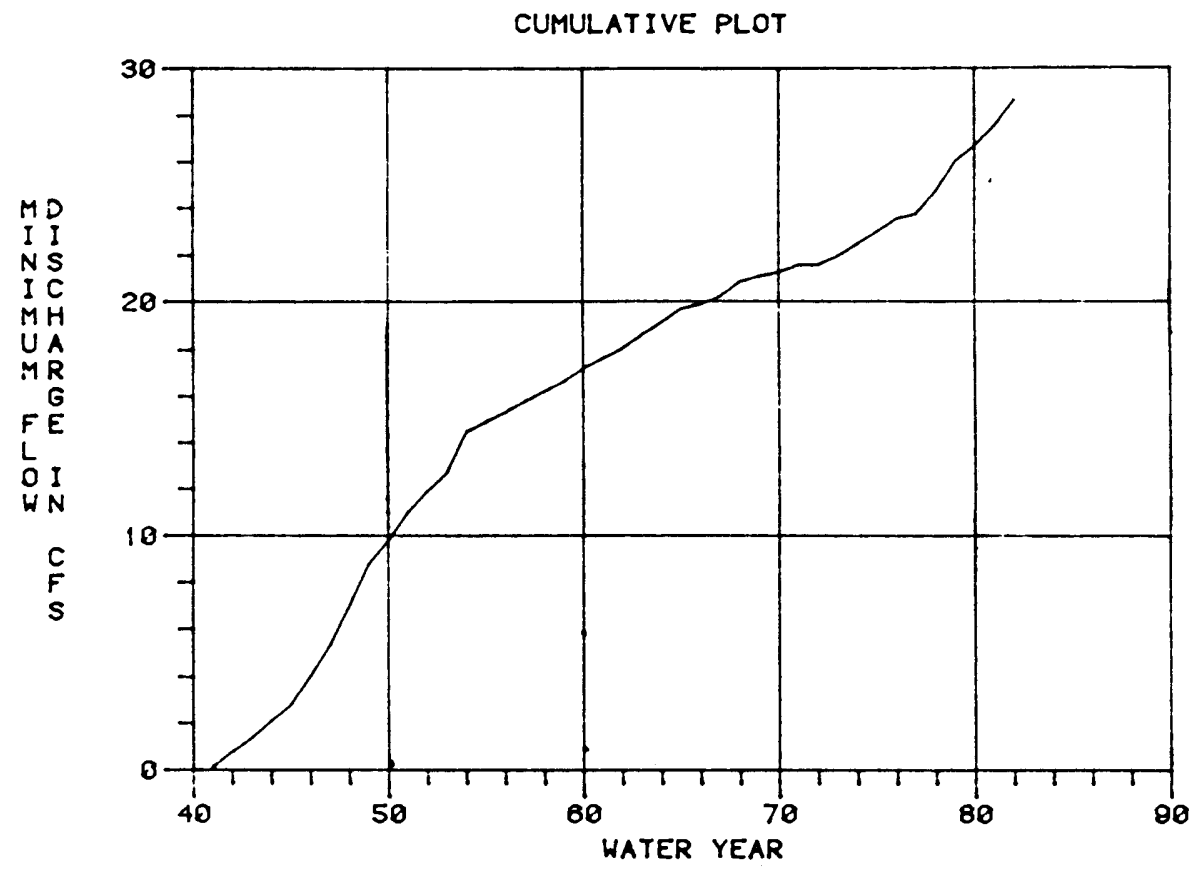

Figure 31. Johnson Creek Minimum Flow Cumulative Plot. (USGS Data) 
TABLE VIII

ANNUAL DATA LINEAR REGRESSION ANALYSIS

Equation: $Y=A+B \star X$

Independent Variable: Water year

\begin{tabular}{|c|c|c|c|}
\hline a & $\begin{array}{l}\text { Regression } \\
\text { Equation }\end{array}$ & $\begin{array}{c}\text { Slope } \\
\text { direction }\end{array}$ & $\begin{array}{c}\text { Slope } \\
\text { sig?/prob }\end{array}$ \\
\hline
\end{tabular}

Peakflow

$Y=285 \cdot 9 \emptyset+17 \cdot 17 \star X$

Pos

Yes $/ 0.02$

Minimum Flow $Y=1.29+0.0098 * X$

Neg

No/ 0.076

Total Flow

$Y=17952+47 \cdot 16 * X$

Pos

No/ $0.54 \emptyset$

Total

Precipitation $Y=43.15+\emptyset .1257 * X$

Pos

No/0. 313

Summer

Precipitation $Y=5.1936+\emptyset .0588 * X$

Pos

No/ 0.158

1. Chosen significance level is 0.05

2. Prob is the actual significance level. 
flows. The regression lines for these two variables are depicted in Figures 32 and 33.

To summarize, the annual data series were subjected to a number of statistical tests and graphical analyses, and the results indicate that there was a significant increase in peakflows and a significant decrease in minimum flows between 1941 and 1982 .

\section{UNIT HYDROGRAPH ANALYSIS}

It has been posited that changes in the shape of a unit hydrograph can be analysed to demonstrate a change in the runoff processes in a watershed (Crippen, 1968; Dunne and Leopold, 1978; Lazaro, 1979). Lazaro (1979) suggests that although the unit hydrograph is not as rigorous a tool as some more recently derived watershed modeling techniques, its simplicity and applicability to almost any urban watershed retain its value as an effective hydrologic analysis technique.

The concept of the unit hydrograph (Fig. 34) was developed by Sherman (1932). It is a discharge hydrograph resulting from one unit of direct runoff from a storm of a constant intensity for a specified duration. The theory is based on the assumption that as long as the physical 


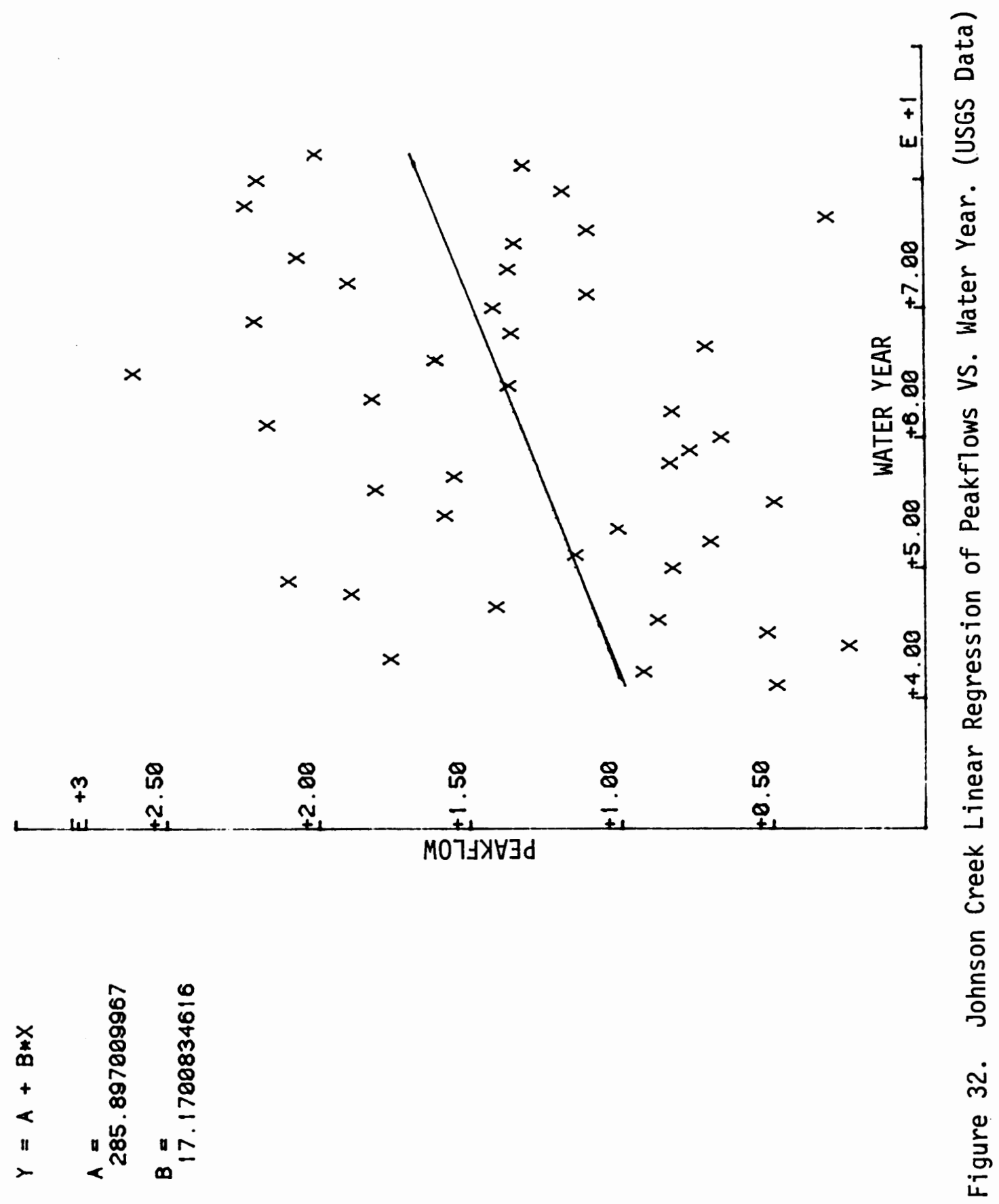




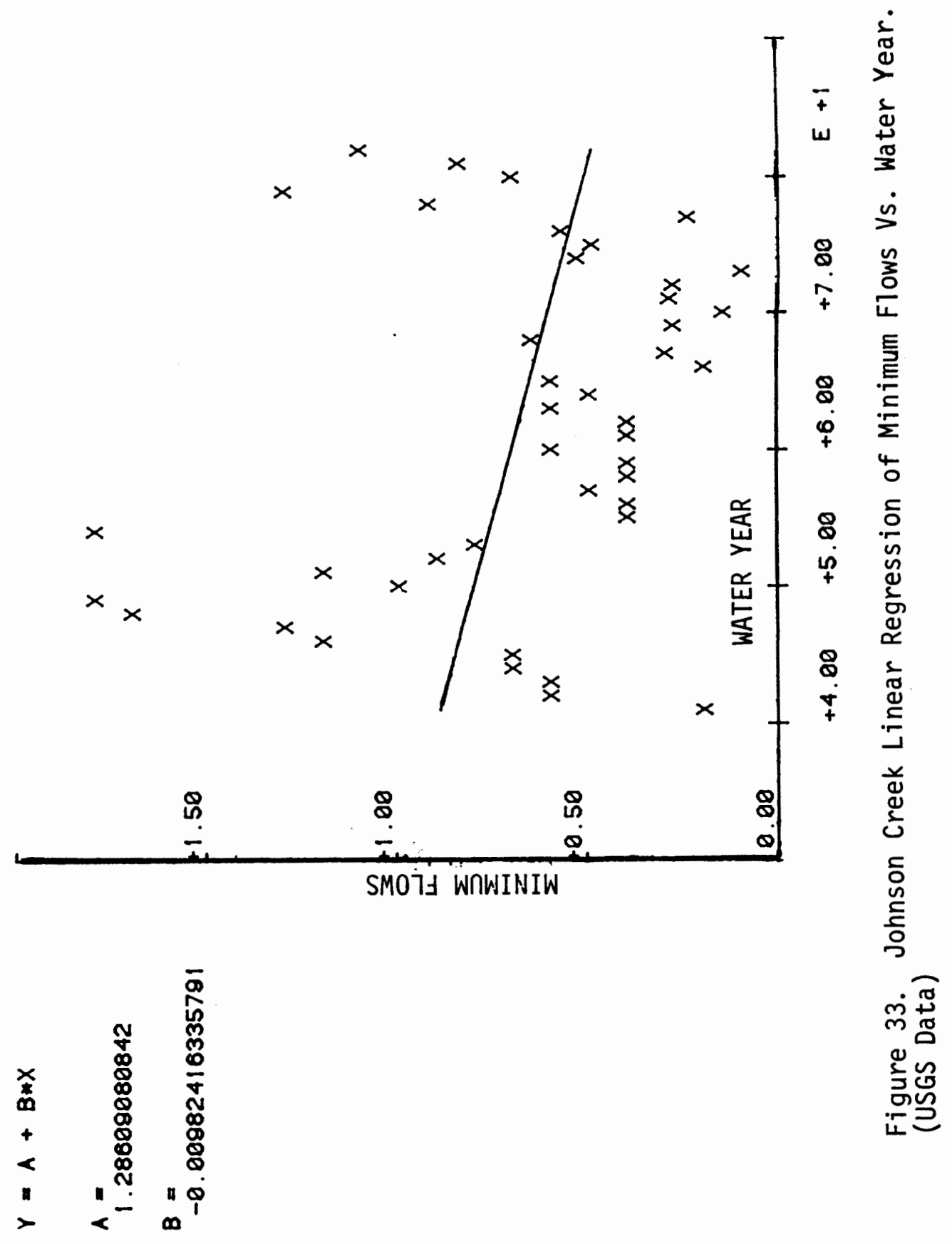




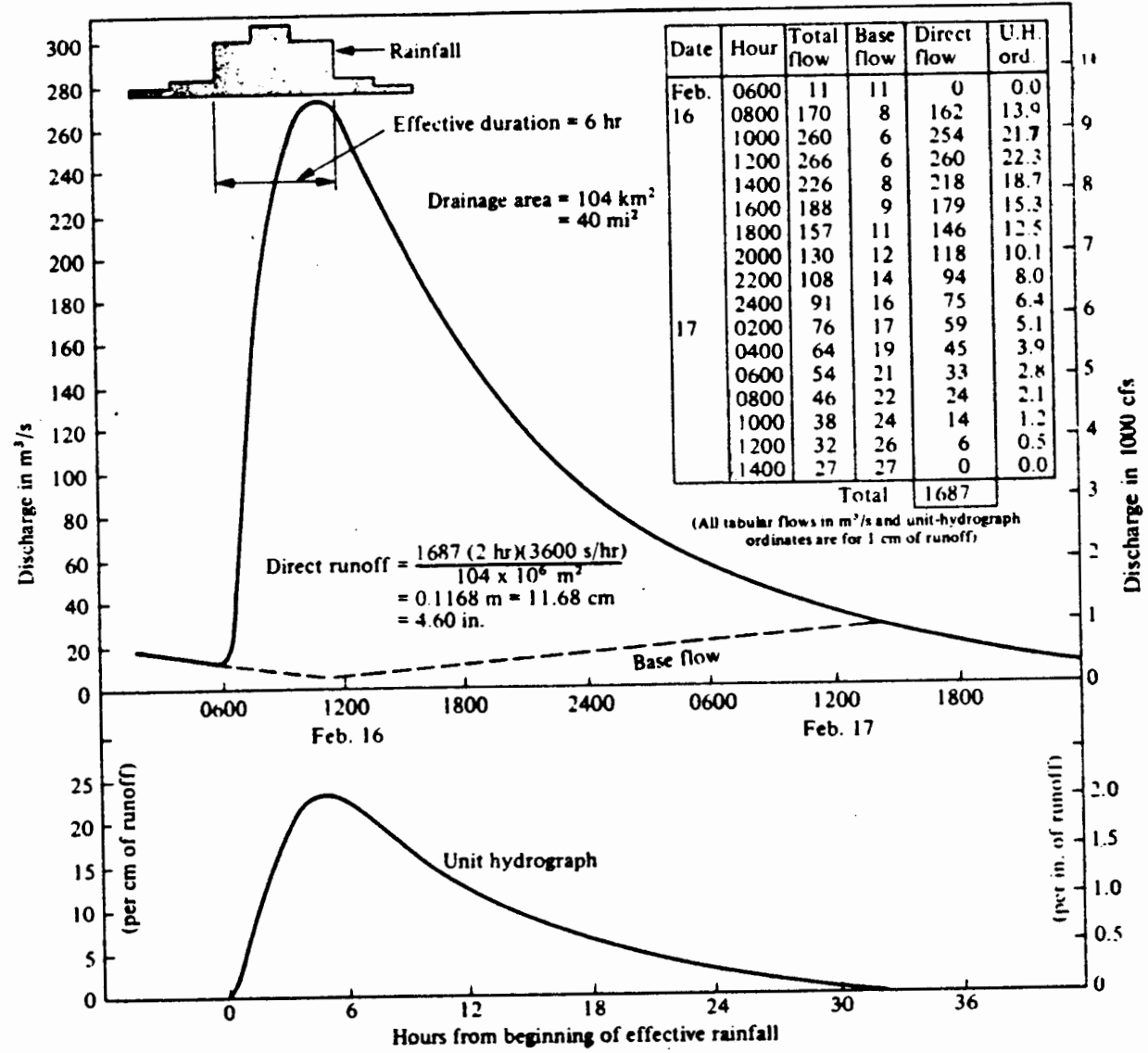

Figure 34. The Unit Hydrograph Calculation Method (Linsley, Kohler and Paulhus, 1982, p. 217) 
characteristics of the basin (size, shape, soil type, vegetation type, land use etc.) are constant, the shape of the unit hydrographs resulting from storms of similar characteristics will be similar (the assumption of linearity).

The outflow hydrograph used in a unit hydrograph analysis must possess a classic hydrograph shape such as that depicted in Fig. 34. Small storm events may result in smaller unit hydrograph peaks than would result from large storm events (Linsley, Kohler, and Paulhus, 1982), hence the runoff events chosen for analysis must be large enough to have resulted from a significant amount of direct runoff.

The variable characteristics of storms that affect hydrograph shape are rainfall duration; time-intensity pattern; areal distribution; and amount (Linsley, Kohler and Paulhus, 1982). The effect of small differences in effective rainfall duration on the unit hydrograph shape is minimal, with an acceptable tolerance of $t /-25$ percent in duration. The assumption of linearity between unit hydrograph ordinates and storms of different durations is not always valid, hence unit hydrographs resulting from storms of the same duration but different precipitation amounts may not have the same shape. To ensure a classic hydrograph shape the storm must consist of a relatively uniform precipitation intensity. The storms must be large 
enough to have covered the watershed in its entirety, or else the resultant hydrograph may be indicative of the characteristics of only one section of the watershed. The amount of rainfall must be enough to result in a significant amount of direct runoff.

Roberts and Klingeman (1970) conducted a study of rainfall-runoff relationships on a scaled down physical model of a watershed. Their results (Fig. 35) show that the more impermeable an area is, the steeper the rising limb and recession curve are in a unit hydrograph. Lazaro(1980), notes that experiments similar to this one "cannot easily be conducted outside the laboratory, since there are a multitude of climatic and physiographic variables to be considered (Lazaro, 1980, p. 28)". Espey et. al. (1969) summarized some earlier urban hydrology studies and concluded that the time of concentration is reduced by approximately 33 percent, and unit hydrograph flows are increased by a factor of three with increased urbanization.

The unit hydrograph calculation method is explained by Linsley and Kohler (1982) and Dunne and Leopold (1978). The runoff hydrograph is plotted, and the baseflow is separated out. The area under the curve is calculated (Fig. 34), reduced to its equivalent depth in inches over the whole watershed, and then the streamflow ordinates on the graph are reduced to a unit hydrograph by dividing them by 


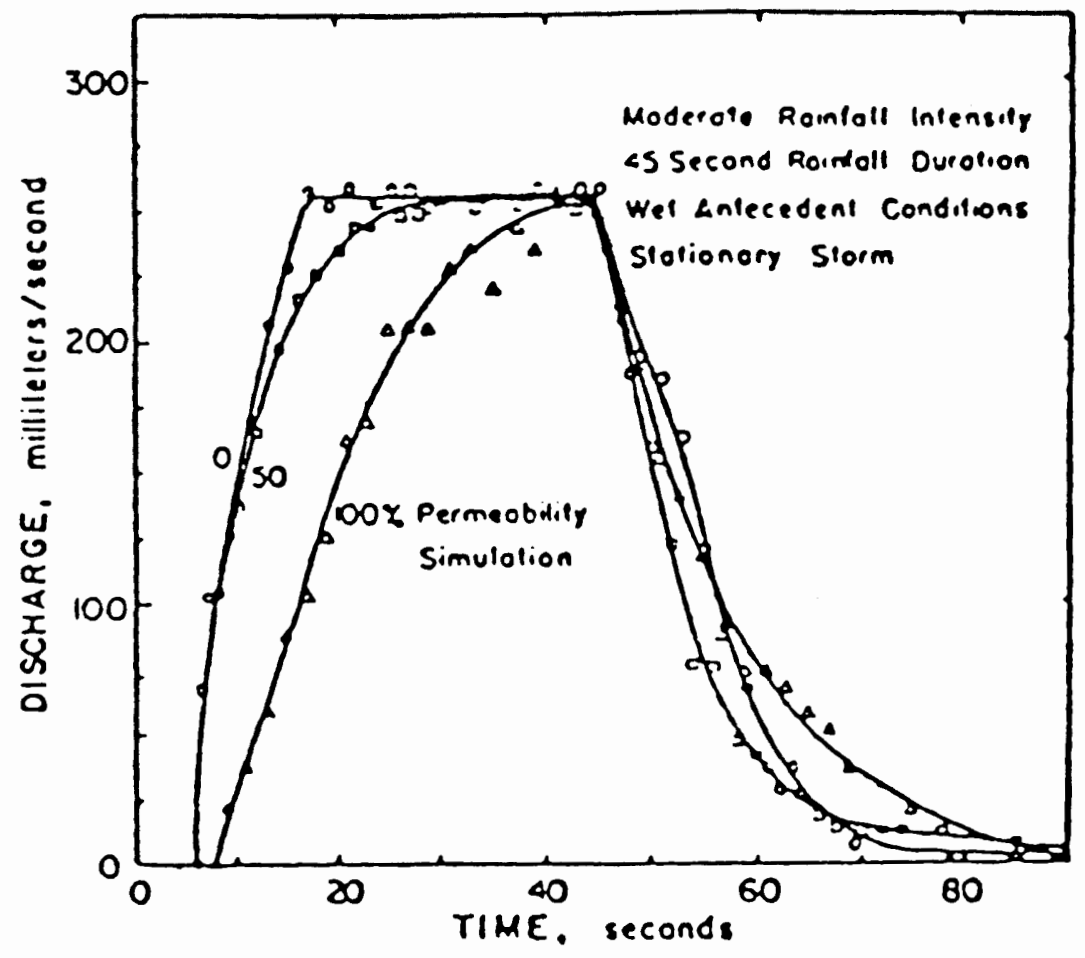

Figure 35. A Unit Hydrograph Comparing Surfaces of $\emptyset, 5 \emptyset$, and $190 \%$ Permeability. (Roberts and K1 ingeman, 1970, p. 405) 
the equivalent depth. To ensure that a unit hydrograph used in an analysis is representative of the unit hydrographs that are characteristic of the basin (as the distribution of rainfall in space and time is unique for every storm), it is usually desirable to average several unit hydrographs resulting from different storms. To average the unit hydrographs, they are plotted, superimposed, and the average peak flow and time to peak is calculated. The rising and recession limbs are sketched in to conform to the general shape of the superimposed unit hydrograph curves, ensuring that the average unit hydrograph curve has a unit volume of one inch.

To determine how the hydrologic response of Johnson Creek has changed since 1941, five storm/flood events were chosen from the early 1940's, six events from the early 1960's, and five events from the early 1980's. Unit hydrographs for each event were calculated, then the unit hydrographs for each period (1940's, 1960's, and 1980's) were averaged into unit hydrographs representing the average storm event for each period. The shapes of the resultant unit hydrographs for each period were compared to determine if any changes had taken place.

A critical phase of this analysis was the selection of storm events. Precipitation and streamflow records were perused to find storm/flood events that met the 
qualifications for a good hydrograph analysis. Data were obtained from several sources. Continuous stage records for the Johnson Creek gaging station at sycamore (\#14211500) were obtained from the USGS Water Resources Division in Portland and seattle, and hourly precipitation data was obtained from the publications of the U.S. Weather Bureau and the NOAA (see bibliography).

As most precipitation events in the Pacific Northwest are cyclonic and are usually not well defined single events, runoff events with the classic hydrograph shape occured rarely and not at all during some years. The high discharge storm events usually come linked together in December and January and are not easily separated. The low discharge storms have inaccuracies inherent in the rating curve at the gaging station, and usually represent runoff from only a small portion of the watershed (depending on the antecedent conditions). For this study storms of different magnitudes were chosen but extremely small storms (less than 100 cfs peak flow) were not used.

Once a few satisfactory runoff events were chosen, the hourly precipitation data were analysed to ensure that (1) The storm events met the qualifications for a good hydrograph analysis and (2) that a consistent data series existed between the storms that generated the runoff events. For this study the effect of rainfall duration was taken 
into account when choosing the storms. The effective storm duration was determined and the storms were compared to ensure the 25 percent range in duration was met. Where the time-intensity patterns of the storms resulted in substantial sub-peaks in the hydrographs, these peaks were either separated out and treated as separate storms or eliminated altogether. The areal distribution of rainfall does not appreciably affect the hydrograph shape in this basin as precipitation during the winter months (from which most of the storms used in this analysis were taken) is cyclonic, and covers an area much larger than the watershed. Observations to the hundredth of an inch at the Gresham precipitation gage were discontinued after the 1960's, therefore hourly data to that precision was obtained from the downtown Portland rain gages. Analysis of isohyetal maps (Fig. 7) indicate that the precipitation in Johnson Creek is 16 percent higher than at the downtown Portland gages. To relate the precipitation in downtown Portland to the watershed, the downtown Portland precipitation was increased by 16 percent. This method was also used by Laenen (1980) in his flooding prediction study of the Johnson Creek watershed. The one hour maximum rainfall that was found in the storms used in this analysis was 0.29 inches (several storms). Note that from Fig. 11 that this intensity has a return period of less than two 
years.

The raw streamflow data (gage heights) were converted to discharge in cfs by the use of rating curves, and then plotted with the precipitation. The lag time (from the center of mass of effective precipitation to the runoff peak flow) was then calculated. Lag time may be calculated to the time of peak flow or the time of the center of mass of direct runoff. In this case as it was decided that as urbanization is relevant to this study (both in that it is the cause of increased peakflows and also as it is where the most property damage occurs as a result of peakflows) peakflows would be used to calculate the lag time.

The baseflow was calculated by extending the recession existing before the storm to a point under the hydrograph peak, then a straight 1 ine was drawn to meet the recession curve at a point two days after flood peak. The two day period was calculated using the formula $\mathrm{N}=\mathrm{A}^{0.02}$ (Area $=26.5$ square miles, $\mathrm{N}=1.93$ days). The lag time, total flow, baseflow, and precipitation were then entered into a computer data file (in the PSU Honeywell), and a FORTRAN program was written to process the data. The program subtracts the baseflow from the total flow to calculate the direct flow for each two hour period; sums up the direct flow; calculates the total direct runoff expressed in inches over the whole watershed; sums up the precipitation; 
calculates the unit graph ordinates; and calculates the amount and percentage of total precipitation which resulted in direct runoff. This amount was used to determine visually the duration of effective rainfall, which was then input to the program. The unit hydrographs were then plotted (using the Tektronix Plot 10 Advanced Graphing II plotting program). This process gives an indication of the amount of initial abstractions.

It should be noted that the percentage of direct runoff gives an indication of the amount of initial abstractions. As it is not the purpose of this thesis to try to model the watershed and create predictive equations (this has been done before, by the NOAA river forecast center, the Corps of Engineers and most notably Laenen (1980)) there was no need to determine the extent of the initial abstractions prior to the data analysis. Subtracting a set amount from the actual rainfall to account for the initial abstractions would actually defeat the purpose of this study, as the changing physical characteristics of the watershed would change the amount of initial abstractions. The purpose of the thesis is to use unit hydrograph analysis as one tool to show how the rainfall-runoff relationships in the watershed (which are affected by the initial abstractions) have changed over time.

This process was repeated for each storm in the 
analysis. The unit hydrographs for each period were then averaged into a unit hydrograph representing the average rainfall-runoff response of the watershed for the time period in question. As the data were already in computer files, it was prudent to use a computer graphics program to graph the more significant variables. The shape of the three representative unit hydrographs were then compared to determine if any changes in the hydrograph shape had occured.

Unit Hydrograph Analysis Results

The results of the analysis are summarized in Fig. 36 and Table IX. Although an effort was made to be consistent while choosing the storms from each period, it is apparent from the coefficients of variation that the storm data from the 1980's was somewhat more variable than the storm data from the earlier periods. The results indicate that the average unit hydrograph peak increased 27 percent, the rising limb has increased in slope by 72 percent, the recession limb has increased in slope by 41 percent, and the time to peak has been reduced by 24 percent. These results correspond with the changes expected to be found as a result of urbanization. However, the 1960's time to peak is 


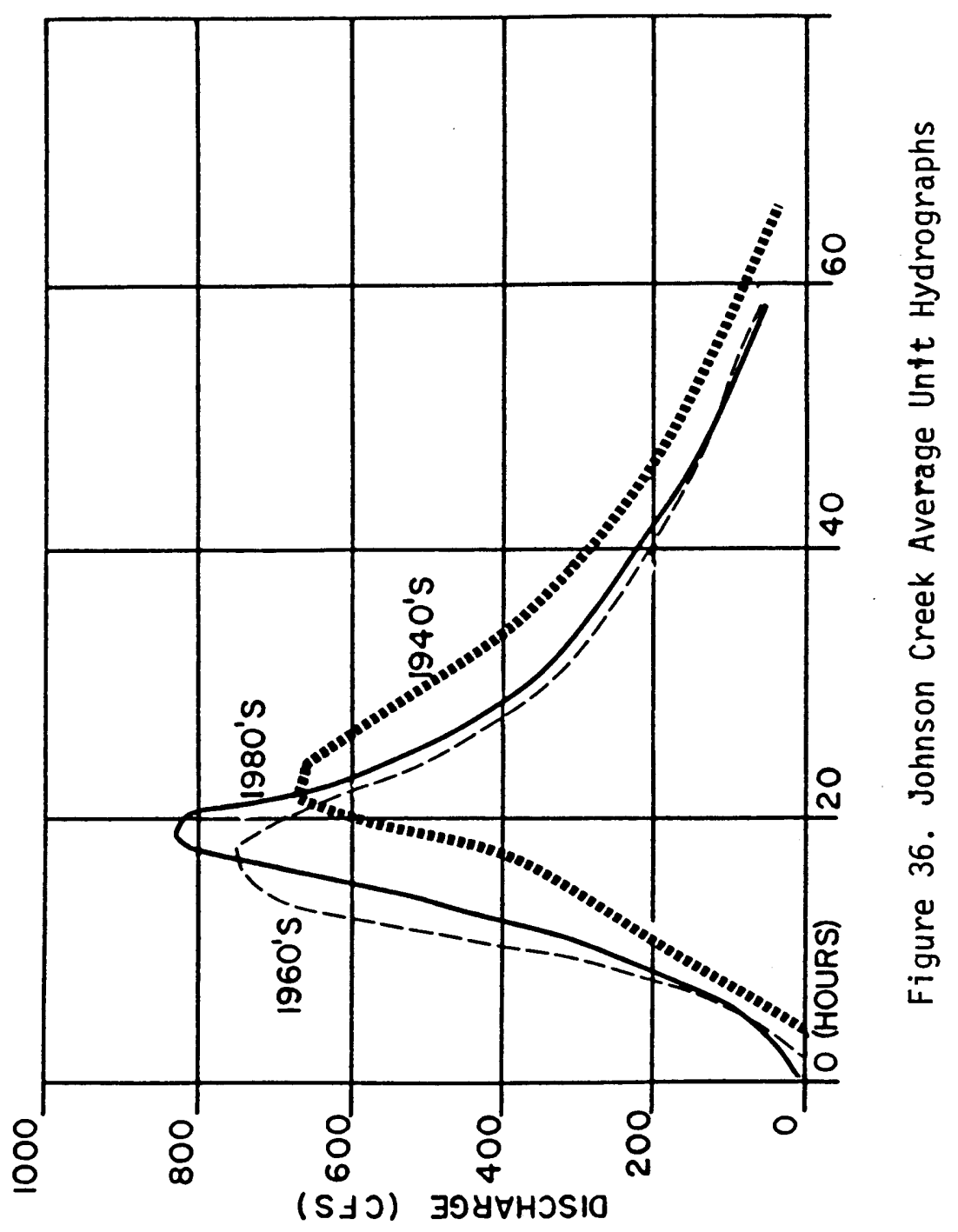




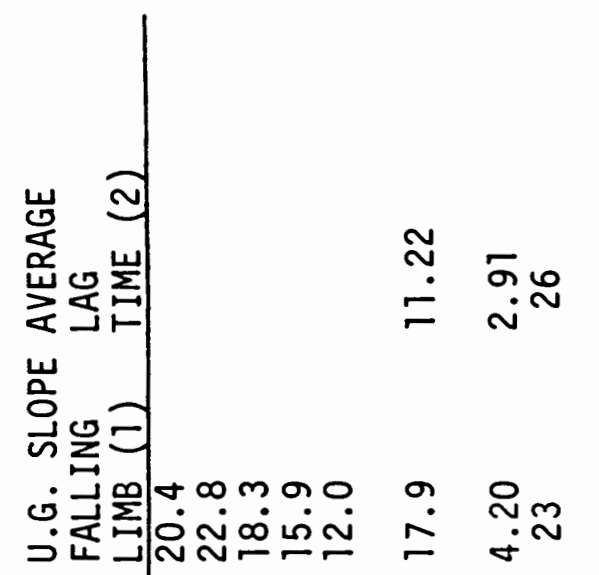

\section{능}

ciّ

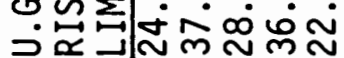

岕关

品昰

背嵒
峲
层司

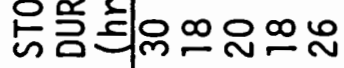

岩

心守

ப⿻

중 는융ㅇㅇ

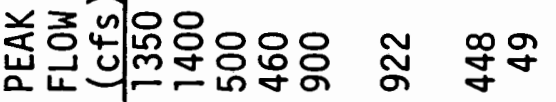

上

$\sum_{\text {tut }}$

岁峞狊

단익 de de ae de

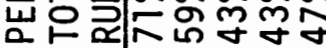

는은

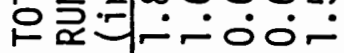
这它

运四

岀 은뭉두

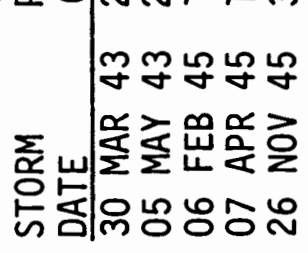

กิ

m

ம

$m \sim \stackrel{m}{n}$

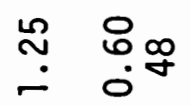

이

i $\dot{0}$

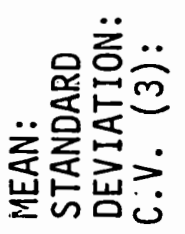

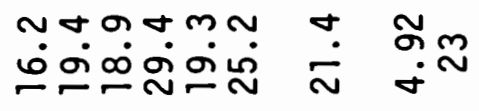

2.0.6.

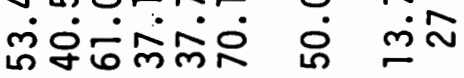

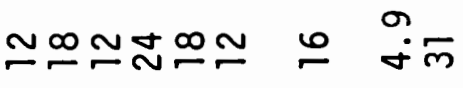

으묘

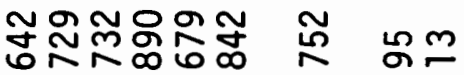

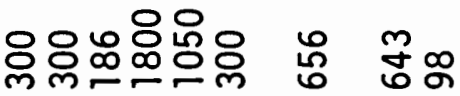

resereserese

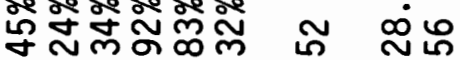

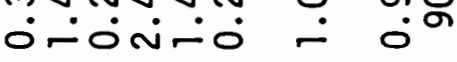

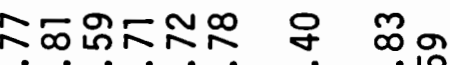
$\dot{0} \dot{0} \dot{0} \dot{0}=\dot{0}^{\circ}$

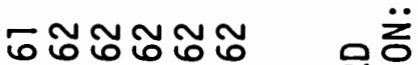

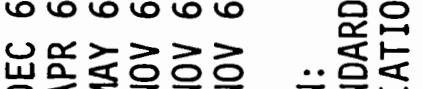

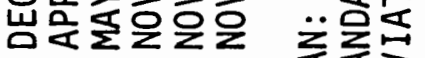

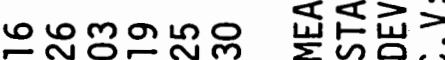




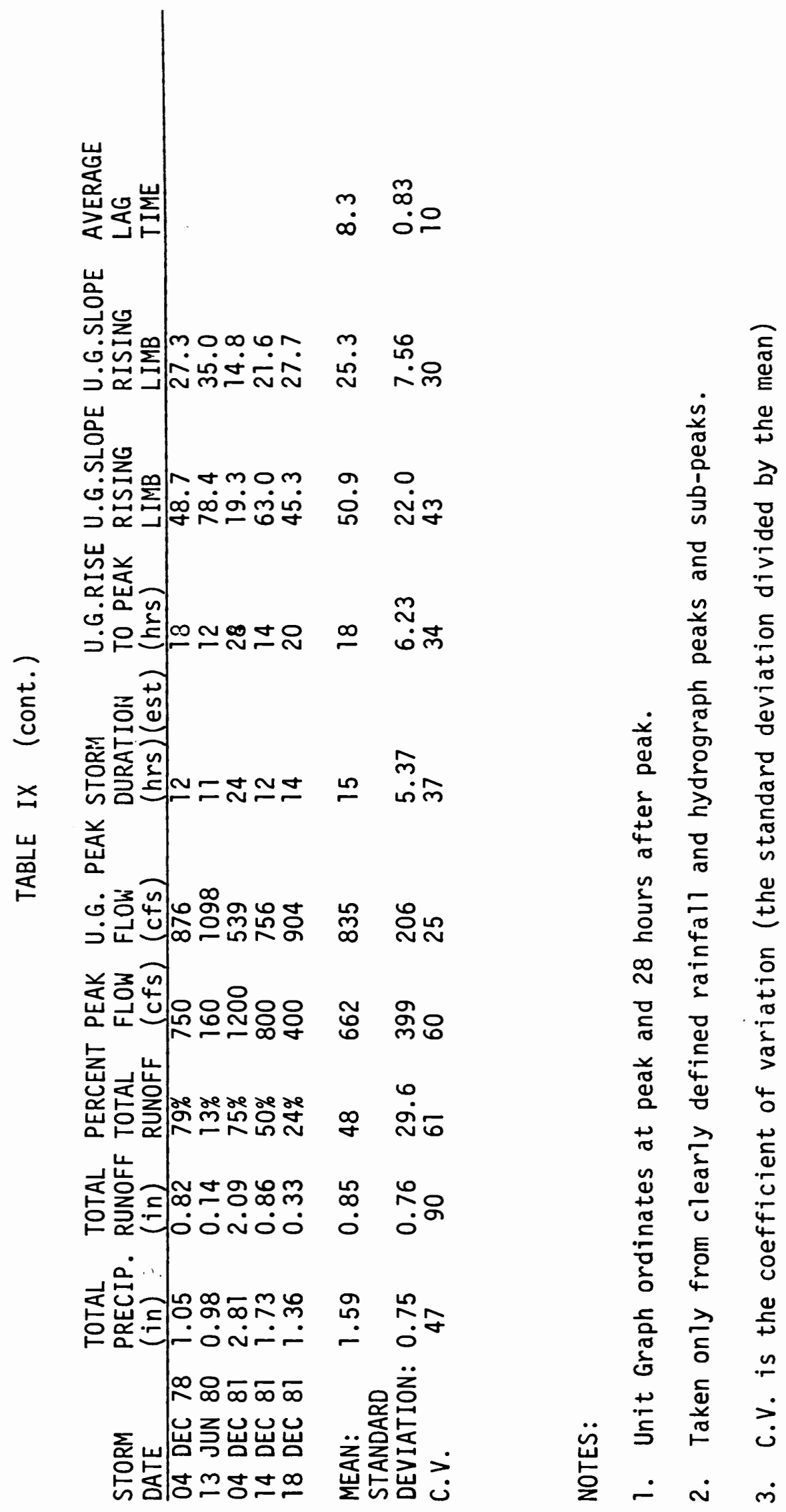


shorter than the 1980's time to peak. This was not expected, and can be attributed to variability in the data and the small sample size.

The average lag time was measured from the center of mass of rainfall to the peak flow. These data were compiled from most of the chosen storms plus some storms that were discarded for other reasons. Sometimes more than one lag time was taken from the same storm when there were several well defined precipitation event-hydrograph sub-peak relationships. In no case was a lag time chosen that was less than eight hours (this was to negate the possible effect of small localized precipitation events that it is assumed may have only affected the lower reaches of the watershed). Several of the storms were of low intensity but long duration, resulting in extremely long lag times, and these were not included in the lag time analysis. The results show a steady decrease in lag times, totaling a 35 percent decrease over the whole period. The results are surprisingly consistent with the hypothesis of hydrologic change with increased urbanization considering the small percentage of the basin (seven percent, Laenen, 1980)) that is considered effectively impervious. This may be explained by the location of the City of Gresham, which is located less than one third of the way up the basin, and contributes a higher percentage of direct runoff to the gaging station 
at a higher rate of speed than the rest of the drainage basin. 
CHAPTER V

CONCLUSION

The purpose of this study was to verify that there has been a change in the rainfall-runoff relationships in the upper Johnson Creek basin since 1941, to quantify this change as indicated by key hydrologic perameters, and to verify that this change had been brought about by urbanization. The Johnson creek watershed was chosen for this study as it is a classic example of full scale urbanization and the role it plays in modifying the hydrologic cycle.

Much information was compiled about the climatic and physiographic characteristics that affect the rainfall-runoff relationship within the Johnson Creek basin. The watershed was found to have many distinct physiographic sub-areas comprised of different underlying geology, soils, geomorphic areas, slopes, vegetation patterns, and land use types that result in a complex interaction between the watershed input (precipitation) and the watershed output (runoff at the stream gage). 
A statistical analysis of key hydrologic parameters (in an annual data series) was performed, comparing two twenty year periods which represent "before" and "after" urbanization conditions. The annual data were tested to see if they fit the assumptions for parametric tests. As they did not, they were then subjected to a number of non-parametric comparative statistical tests. As a result, the possible effects of a climatic change having an annual periodicity were eliminated as a cause for hydrologic change. Minimum flows and peakflows showed a statistically significant decrease and increase respectively.

A time series/regression analysis was performed on the annual data to detect any apparent progressive change in the hydrologic parameters. The results indicate that peakflows possessed a significant positive slope and that minimum flows possessed a negative slope with an observed significance level close to the chosen significance level.

Storm data from the 1940's, 1960's and 1980's were analysed for consistency and suitability for a unit hydrograph analysis. The storms chosen from each time period were then reduced to unit hydrographs, averaged, and compared. The comparative unit hydrograph analysis indicated an increase in unit hydrograph peak flows, a shortening of the unit hydrograph time to peak, a steepening of both the rising limb and the recession curve, and a 
reduction in precipitation-event hydrograph-peak lag times.

During the course of this study seltzer (1983) published a dissertation that included an analysis of the return periods of discharge in Johnson Creek (Fig. 37). The results of his analysis correspond well with the results of the current study, showing an obvious increase in discharge for each recurrence interval between the periods 1941 to 1960 and 1961 to 1980. Thus the null hypothesis of no change in the rainfall-runoff relationship was discredited.

Laenen(1980), determined that effective impervious area was a significant predictive perameter of regression equations used to predict stormflows in the Johnson Creek Basin, and that the effective impervious area was a result of urbanization.

A comparison of Table IV with Tables VII, VIII, and IX give an indication of the cause of the hydrologic changes outlined in this report. The City of Gresham increased in population by 102 percent between 1940 and 1960, and increased by 704 percent between 1961 and 1979, for an overall increase of over 1526 percent. Using data from Table VII, it can be determined that mean and median minimum flows decreased by 37.2 and 26.0 percent, respectively, and that mean and median peakflows increased by 34.7 and 47.0 percent, respectively. Data from Table VII indicates that peakflows increased by 14 percent from the 1940 's to the 


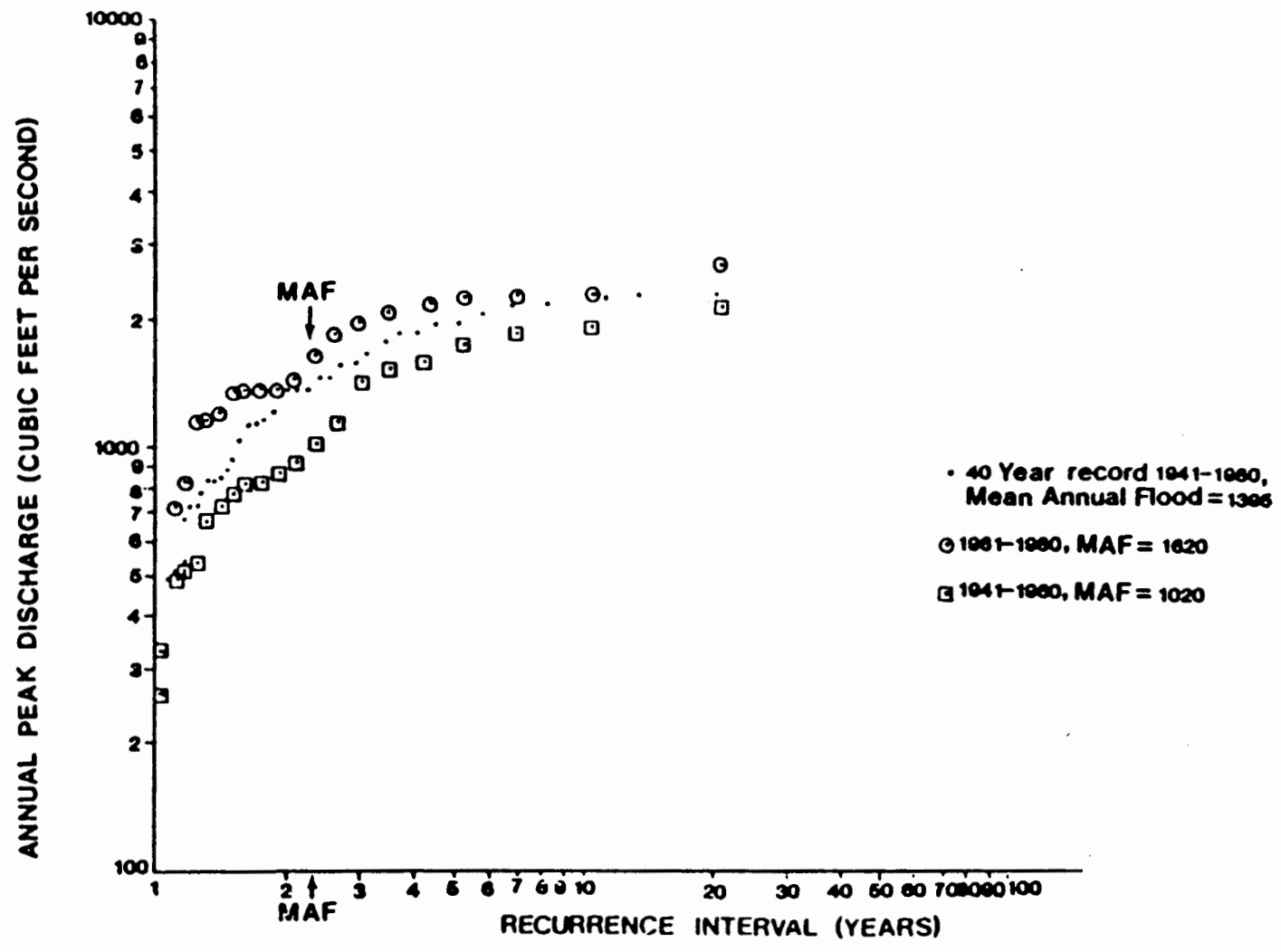

Figure 37. Johnson Creek Flood Frequency Curves (Seltzer, 1983, p. 110) 
$1960^{\prime}$ 's, and by 11 percent from the 1960's to the 1980's, for an overall increase of 27 percent. Lag times showed an overall decrease of 26 percent from the 1940's to the 1980's. These findings and the findings of Laenen indicate that the one tailed alternate hypothesis of a significant hydrologic change due to urbanization should be accepted.

There is room for further urbanization within the watershed, and as Patrick Henry once said, "I know of no way of judging of the future but by the past" (speech to the Virginia convention, Richmond, March 23rd, 1775). This concept may be applied to the Johnson Creek watershed in two ways. First, without severe restrictions on population growth within the basin it is likely that urbanization will continue. Second, future urbanization will affect the rainfall-runoff relationships in the basin as documented in this report. It is hoped that this thesis will contribute to an understanding of the ongoing hydrologic change, and that this report will make it easier for citizens and decision makers to rectify the urbanization/flooding problem. 
REFERENCES

American Society of Civil Engineers, Basic Information Needs In Urban Hydrology ASCE, New York, 112 Pp, 1969.

Anderson, D.G, Effects of Urban Development on Floods in Northern Virginia, United States Geological Survey Water Supply Paper \#2001-C, USGPO, Washington, 22 pp, 1968 .

Betson, R.P, "What is Watershed Runoff?," J. Geophys. Res, $69(8), 1541-1552,1964$.

Brater, E.F, "Steps toward a Better Understanding of Urban Runoff Processes," Water Resources Res, 4(2), 335-347, 1968.

Brown and Caldwell, City of Gresham Sewerage Master Plan, Eugene, Oregon, 1980 .

Carter, R.W, Magnitude and Frequency of Floods in Suburban Areas, USGS Prof. Paper 424-B, B9-B11, 1961.

Chorley, R.J, and Kennedy, B.A, Physical Geography: a Systems Approach, Prentice Hall International Inc, London, 370 pp, 1971.

Chow, V.T. (ed.), Handbook of Applied Hydrology, McGraw-Hill, New York, 1964.

City of Gresham, Gresham Community Development Plan, Gresham, Or, 1980 . 
Columbia Regional Association of Governments (CRAG), CRAG Drainage Plan (Addendum Report 1), Portland, or, 96 pp, 1971.

Cordery, Ian, "Initial Loss for Flood Estimation and Forecasting", J. Hyd. Div, ASCE, 96, (HY12), 2447-2466, 1970 .

Crippen, J.R, Changes in the Character of Unit Hydrographs, Sharon Creek, California, After Suburban Development, USGS Prof. Paper 525-D, D196-D198, 1965,

Dawdy, D.R, Considerations Involved in Evaluating

Mathematical Modeling of Urban Hydrologic Systems,

USGS Water Supply Paper 1591-D, USGPO, Washington, D.C, 1969 .

Dunne, T, and Leopold, L.B, Water in Environmental Planning, W.H. Freeman and Co, san Francisco, 818 pp, 1978.

Espey, W.H. et al, "Urban Effects on the Unit Hydrograph," in Effects of Watershed Changes on Streamflow, Wl Moore and CW Morgan, ed's, Austin: Univerrsity of Texas Press, 215-228, 1969.

Espey, W.H. Jr, and Winslow, D.E, "Urban Flood Frequency Characteristics", J. Hyd. Div, ASCE, 100(HY2), 279-293, 1974 .

Franklin, J.F, and Dryness, C.T, Natural Vegetation of Oregon and Washington, USDA-Forest Service Technical Report PNW-8, USGPO, Washington D.C, 417 pp, 1973.

Gluck, W.R, and McCuen, R.H, "Estimating Land Use Characteristics for Hydrologic Models", Water Resources Res, 11(1), 177-179, 1975 .

Green, G.L, Soil Survey of Multnomah County, Oregon, USDA, SCS, USGPO, Washington, D.C, 225 pp, 1983 . 
Griffiths, J.F, and Griffiths, M.J, Bibliography of the Urban Modification of the Atmosphere and the Hydrologic Environment, NOAA Tech. Memorandum EDS-21, US Dept of Commerce, Washington, D.C, 92 pp, 1974.

Haan, C.T, Statistical Methods in Hydrology, The Iowa State University Press, Ames. 378 pp, 1977.

Harris, E.E, and Rantz, S.E, Effect of Urban Growth on Streamflow Regimen of Permanente Creek Santa Clara County California, USGS Water Supply Paper 1591-B, USGPO, Washington, $18 \mathrm{pp}, 1964$.

Hicks, W.I, "A Method of Computing Urban Runoff," Transactions, ASCE, V. 109, 1217-1268, 1944.

Hogenson, G.M, and Foxworthy, B.L, Groundwater in the East Portland Area; Oregon, USGS water Supply Paper 1793, USGPO, Washington, $78 \mathrm{pp}, 1965$.

Horner, W.W, and Flynt,F.L, "Relations Between Rainfall and Runoff From Small Suburban Areas," Transactions, ASCE, V. $101,140-206,1936$.

Hull, C.H, and Nie, N.H, SPSS Update 7-9, Mcgraw-Hill Book Co, New York, 402 pp, 1981 .

Izzard, C.F, "Hydrology of Runoff From Developed Surfaces," Proc. Highway Research Board, V. 26, 129-150, 1946.

James, D.L, "Using a Digital Computer to Estimate the Effects of Urban Development on Flood Peaks," Water Resources Res, l(2), 223-234, 1965.

Johnson, D.M, and Dart, J.0, Variability of Precipitation in the Pacific Northwest: Spatial and Temporal Characteristics, Geography Dept, Portland State University, Portland, oregon, $182 \mathrm{pp}, 1982$. 
Jones, D.E. Jr, "Where is Urban Hydrology Practice Today?" Proc. ASCE, Hydr. Div, 97 (HY2), 257-264, 1971 .

Knapp, G.L, and Glasby, J.P, Urban Hydrology: a Selected Bibliography with Abstracts, USGS Water Resource Investigations 3-72, USGPO, Washington, D.C, 211 pp, 1973.

Kuichling,E, "The Relation Between the Rainfall and the Discharge of Sewers in Populous Districts,"

Transactions, ASCE, Vol. 20, 1-56, 1889,

Laenen, A, Storm Runoff as Related to Urbanization in the Portland, Oregon-Vancouver, Washington area, USGS Open File Report 8ø-689, Portland, Oregon, $71 \mathrm{pp}, 198 \emptyset$.

Lazaro, T.R, Urban Hydrology, Ann Arbor Science Publishers, Ann Arbor, Mich, 249 pp, 1980.

Leopold, L.B, Hydrology for Urban Land Planning- A guidebook on the Hydrologic Effects of Urban Land Use, USGS Cir. 554, USGPO, Washington, 18 pp 1968.

- "Rainfall Frequency: An Aspect of Climatic

Variation", Trans. Am. Geophys. Union, (EOS), 32(3), 347-357, 1951.

Linsley, R.K. Jr, Kohler, M.A, and Paulhus, J.L.H, Hydrology For Engineers, McGraw Hill Book Co, New York, 508 pp, 1982 .

Loy, w, et. al. The Atlas of Oregon, University of Oregon Books, Eugene, Oregon, 1976.

Magnani, S, Along Johnson Creek, METRO, Portland, Oregon, 1981. (pamphlet). 
Manning, $R$, "Observations on Subjects Connected With Arterial Drainage," Proc.Inst. Civ. Engineers of Ireland, 9ø-104 May 1851 .

Martens, L.A, Flood Inundation and Effects of Urbanization in Metropolitan Charlotte North Carolina, USGS Water Supply Paper 1591-C, USGPO, Washington, 60 pp 1968.

McCuen, R.H, and James, D. L, "Nonparametric Statistical Methods in Urban Hydrologic Research," Water Resources Bull, 8(5), 965-975, 1972 .

McKenzie, S.W, and Miller, T.L, Basic Data on Urban Stormwater Quality, Portland Oregon, USGS Open File Report 76-594, 71 pp, 1976.

McPherson, M.B, Hydrological Effects of Urbanization, Paris: UNESO Press, 1974.

Metro Service District, "Storm Water Management Design Manual," Technical Supplement 13 to Areawide Waste Treatment Management Study, Metro, Portland, Oregon. 1980 .

- Drainage Management in the Johnson Creek Basin, (METRO Staff Report), METRO, Portland, Or, 105 pp, 1975.

Morgan, R, and Hullinghors, D.W, Unit Hydrographs for Gaged and Ungaged Watersheds, (unpublished manuscript) US Engineers Office, Binghamton, NY. July, 1939.

Moses, L.E, "Non-Parametric Statistics for Psychological Research," Psychological Bulletin, 49(2), 122-143, 1951 . 
Mulvaney,T.J, "On the Use of Self Registering Rain and Flood Gages in Making Observations of the Relations of Rainfall and Flood Discharges in a Given Catchment", Proc. Inst. Civ. Engineers of Ireland, (4) 18-31, 1850-1851.

Nie,N.H. et. al, Statistical Package for the Social Sciences, MCGraw-Hill Book Co, New York, 675 pp, 1970.

Norsus, M.J, SPSS Introductory Guide: Basic Statistics and Instructions, McGraw-Hill Book Co, New York, 173 pp, 1982.

Peterson, R.M. and Johnson, D.M, "Drainage Basins Report," Portland Metropolitan Area Urban Runoff Study, Portland State University, Portland, 28 pp, 1981.

Ponce,S.L, Statistical Methods Commonly Used in Water Quality Analysis, Watershed Systems Development Group, Ft. Collins, CO, $146 \mathrm{pp}, 1980$.

Portland State University (PSU) Population Center, Population Estimate of Counties and Incorporated Cities in Oregon, PSU, Portland, Or, 1978.

Price, L.W, Biogeography Field Guide to the Cascade Mountians, Dept. of Geography, Portland State University, Portland, Or, 36 pp, 1971.

Roberts, M.C, and Klingeman, P.C, "The Influence of Landform and Precipitation on Flood Hydrographs," J. Hydrol, $11,393-411,1970$.

Savini, J, and Kammerer, J.C, Urban Growth and the Water Regimen, USGS Water Supply Paper 1591-A, USGPO, Washington, $43 \mathrm{pp}, 1961$. 
Schulz, E.F, and Lopez, O.G, Determination of Urban Watershed Response Time, Hydrology Papers, Colorado State University, Ft. Collins, Colorado, 41 pp 1974.

Seaburn, G.E, Effects of Urban Development on Direct Runoff to East Meadow Brook, Nassau County, Long Island, New York, USGS Prof. Paper 627-B, USGPO, Washington D.C, $\overline{1969 .}$

Seltzer,E.P, Citizen Participation in Environmental

Planning: Context and Consequence, Doctoral

Dissertation, University of Pennsylvania, Philidelphia, 238 pp, 1983.

Sherman, L.K, "Stream Flows From Rainfall by the Unit Graph Method," Engineering News Record, V. 108, 501-505, 1932 .

Siegel, S, Non-Parametric Statistics for the Behavioral Sciences, McGraw-Hill Book Co, New York, 312 Pp, 1956.

Snyder,F.F, "Synthetic Unit Graphs," Trans. Amer. Geophys. Union, Pt. 1, 447-454, 1938 .

Stankowski, S.J, Population Density as an Indicator of Urban and Suburban Land-Surface Modifications, USGS Professional Paper 8øø-B, B219-B224, 1972 .

State of Oregon Department of Environmental Quality (DEQ), Water Quality in Johnson Creek, 197ø-1975, State of Oregon, Salem, Or, $24 \mathrm{pp}, 1975$.

Stevens, Thompson and Runyon, Inc. (ST\&R), Drainage study for the City of Gresham, Or, ST\&R, Portland, Or, 1972 .

Tate, M.W, and Clelland, R.C, Non-Parametric and Shortcut Statistics, Interstate printers and Publishers, Danville, Ill, 171 pp, 1957. 
Tholin, A.L, and Keifer, C.J, "Hydrology of Urban Runoff," Transactions, ASCE, V.125, 1308-1379, 1960 .

U.S. Army Corps of Engineers, Portland Vancouver

Metropolitan Area Water Resources Study, US Army

Engineer District, Portland, Oregon, 1977.

- Design Memorandum: Johnson Creek at Portland and Vicinity, Oregon, U.S. Army Engineer District, Portland, Or, 1975 .

- Proceedings of a Seminar on Urban Hydrology, The Hydrologic Engineering Center, Davis, California, 1970 .

U.S. Dept. of Agriculture Soil Conservation Service, Guide for Using Soil Survey Single Phase Interpretation Sheets, SCS, Portland, OR, $28 \mathrm{pp}, 1983$.

U.S. Dept. of Commerce National Oceanic and Atmospheric Administration (NOAA), Local Climatological Data: Portland, Oregon, Annual Summary With Comparative Data, National Climatic Center, Asheville, N.C. 1983,

U.S. Dept. of Commerce Weather Bureau, Rainfall

Duration-intensity-Frequency Curves for Selected Stations in the United States, Alaska, the Hawailian Islands, and Puerto Rico, U.S. Weather Bureau Technical Paper \#25, 1955 .

Trimble, D.E, Geology of Portland, Oregon, and Adjacent Areas, USGS Bull. 1119, USGPO, Washington, 1963.

Waananen, A, 0, Hydrologic Effects of Urban Growth: Some Characteristics of Urban Runoff, USGS Prof. Paper 424-C, C353-C356, 1961.

Wallace, J.R, The Effects of Land Use Change on the Hydrology of an Urban watershed, Georgia Institute of Technology, Atlanta, Ga, 36 pp, 1971 . 
Wantz, B, Feris, C.M, and Larsen, N.S, Fifteen Year Average Precipitation Patterns as Revealed by the Portland, Oregon, Mesoscale Network, Bonneville Power Administration (unpublished), Portland, Oregon, 13 pp, 1983 .

Witala, S.W, Some Aspects of Urban and Suburban Development on Runoff, USGS Open File Report, 28 pp, 1961.

World Meterological Organization (W.M.O.), Climatic Change Tech. Note no. 79, Geneva, Switzerland, 1966. 